\title{
DOE/HR - . O190
}

\section{U.S. Department of Energy}

\section{Information Architecture Volume IV}

\section{Vision}

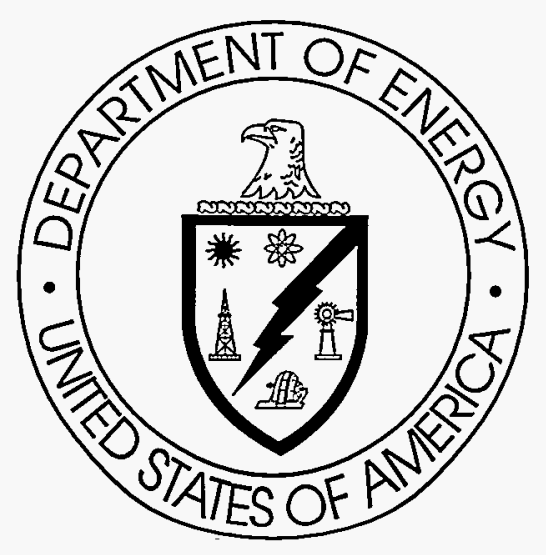

MASTER

March 1998

DSGTRISUTION OF THIS BOCURAENT IS

Assistant Secretary for Human Resources and Administration
Deputy Assistant Secretary for Information Management 
The Architecture, Standards, and Engineering Group (HR-43), of the Office of Information Management (and supporting contractor resources) are available for consultation concerning alignment with the Departmental information architecture and on the processes and approaches being utilized in the development and documentation of site and program information architectures. For more information, contact Michael Tiemann (202-586-5461 or michael.tiemann@hq.doe.gov). 


\section{DISCLAIMER}

This report was prepared as an account of work sponsored by an agency of the United States Government. Neither the United States Government nor any agency thereof, nor any of their employees, makes any warranty, express or implied, or assumes any legal liability or responsibility for the accuracy, completeness, or usefulness of any information, apparatus, product, or process disclosed, or represents that its use would not infringe privately owned rights. Reference herein to any specific commercial product, process, or service by trade name, trademark, manufacturer, or otherwise does not necessarily constitute or imply its endorsement, recommendation, or favoring by the United States Government or any agency thereof. The views and opinions of authors expressed herein do not necessarily state or refiect those of the United States Government or any agency thereof.

$$
\text { - }
$$




\section{DISCLAIMER}

Portions of this document may be illegible electronic image products. Images are produced from the best available original document. 


\section{Message from the Chief Information Officer}

I am pleased to present the Information Architecture, Volume IV, Vision document. This document represents the final step in the definition stage of the Information Architecture Program and a transition from definition to implementation of site architectural efforts. The process-oriented approach should allow sites and Departmental Elements to define architectures for their respective areas that nest into the overall Departmental architecture.

The Department of Energy (DOE), like other Federal Agencies, is under increasing pressure to use information technology (IT) investments to improve efficiency in mission accomplishment, as well as delivery of information and services to the public. The relationship to legislative mandates and increased commitment to proactive management of Governmental information resources advanced by the Clinger-Cohen Act of 1996 requires Agencies to implement architectures to facilitate information exchange, increase sharing, and reduce costs by eliminating redundancy in development and acquisition of systems.

At DOE, I am particularly proud that several programs and sites have been working on architectures. In my role as Chief Information Officer (CIO), I encourage each DOE Element to pursue an information architecture that meets its individual information needs. At the same time, I have encouraged the establishment of groups across DOE Elements to deal with issues of common concern. These groups ensure that common directions are pursued or that allowances are made to achieve compatibility and interoperability when directions diverge. The Corporate Guidance Group, the Headquarters Collaboration Group, and the DOE IT Standards Program work closely with the DOE Information Architecture Program. The efforts of each of these groups are represented in this Vision document.

I look forward to working with business partners, the Executive Committee for Information Management, the Information Management Council, and site CIOs across the DOE complex to implement the Information Architecture Program within the Department.

S. W. Hall, Jr.

Chief Information Officer 


\section{Message from the Information Architecture Program Manager}

This document represents the capstone in a process-oriented approach for aligning technology with Departmental missions. The DOE Information Architecture Program, established over the past 3 years through the efforts of Information Management Planning and Architecture Coordinating Team (IMPACT), is recognized Governmentwide as a best business approach. This final defining document synergistically captures the essence of the planning efforts and provides a pragmatic approach for the transformation of the vision to implementation.

We have completed only the beginning of our journey towards executing information architecture. Much work remains. The stakes are high, as are the potential rewards. Our hope is that this document will spur the additional thinking, dialogue, and actions that must occur to achieve the vision.

The timeframe for this vision is approximately 7 years. This vision reaches over the horizon to capabilities to be provided by an architected environment. The picture of success described in this document is attainable through the application of disciplined processes that are real and have been successfully piloted in one DOE Program Office, Energy Research, and through processes employed at other DOE sites.

In chapter 4 of this volume, we continue a fictional story in sidebars involving Shirley Greyhorse and Ray Saunders, who were introduced in Information Architecture, Volume I, Foundations. Shirley looks back to how her success is based on her earlier participation in defining a business-needs-driven architecture. She is assisted by a virtual team in putting together a rapidly deployed application in 2005 . The story illustrates how the architecture sets the stage to attain rapid business success in the future through a fully architected environment.

As the leader of the IMPACT Team and the Program Manager of the information architecture, it has been my privilege to work closely with literally hundreds of dedicated information management and other professionals throughout this Department, its supporting contractors, and with various others in Government and private industry. I have had support from my management and colleagues and for this I am grateful and humbled. To all those listed on the credits page and the many others who participated in this journey, I am very grateful. We have made an IMPACT!

Michael A. Tiemann

Information Architecture Program Manager 


\section{Executive Summary}

The Vision document marks the transition from definition to implementation of the Department of Energy (DOE) Information Architecture Program. A description of the possibilities for the future, supported by actual experience with a process model and tool set, points toward implementation options. The directions for future information technology investments are discussed. Practical examples of how technology answers the business and information needs of the organization through coordinated and meshed data, applications, and technology architectures are related.

This document is the fourth and final volume in the planned series for defining and exhibiting the DOE information architecture. The targeted scope of this document includes DOE Program Offices, field sites, contractor-operated facilities, and laboratories.

This document paints a picture of how, over the next 7 years, technology may be implemented, dramatically improving the ways business is conducted at DOE. While technology is mentioned throughout this document, the vision is not about technology. The vision concerns the transition afforded by technology and the process steps to be completed to ensure alignment with business needs. This goal can be met if those directing the changing business and missionsupport processes understand the capabilities afforded by architectural processes.

A clear, understandable message must be conveyed to facilitate, support, and sponsor collaboration. Each DOE employee, Federal or contractor, must embrace these changes even though they may appear to be radical. Accepting these changes will enable the Department to do many things more efficiently. Such a culture change is desirable and is inherent in an architected environment.

Chapter 1, Architectural Vision Drivers, highlights legal mandates, policies, and other factors promoting the DOE information architecture efforts. Increasingly, return on technology investments must be estimated before implementation and tracked during it. The goals of the current DOE Information Management Strategic Plan center around the layers of the DOE information architecture conceptual model.

Chapter 2, Information Architecture Model Evolution, defines the evolution of the information architecture framework from a conceptual to a process-driven model. It provides guidance for formulating site architectures that are compatible, scalable, interoperable, and, most importantly, business-needs-driven. Discussion of the practical implications of architecture-based planning is provided to build the case to proceed into a fully architected information technology environment. 
Chapter 3, Departmental Vision, expands the Departmental enterprise vision to include descriptions for the future for each of the five layers: business, information, data, applications, and technology. Contributions from the dedicated information management and business professionals at IMPACT Meetings IV and V are included. They form the basis for common understanding of the information architecture and architectural process across the breadth of the enterprise.

The vision provides the framework for strategic direction that speaks meaningfully to both business managers and supporting technologists. The Departmental vision defines the scope of the information architecture, while the business layer focuses on the business context of missions as described in the DOE Strategic Plan. Information and data are corporate assets for which DOE is the steward. The models describe the data required to meet business needs and where the data is created, used, and stored.

Applications are the tools used to create and manage data components to deliver information when and where it is needed. Building and acquiring functioning systems requires sequencing to ensure that components work together and that the technology platform supports their implementation. The technology architecture addresses the infrastructure and other technical components that underpin and support serving business needs through applications that provide mission-essential data and information.

Chapter 4, Architecture in Action, provides a step-by-step description of an enterprise architecture process. Requirements for planning, resources, and support are identified, along with sample tools and products. The case study is illustrated with references to the Energy Research architecture process, the DOE Standards program, and other current priority initiatives to demonstrate the architectural process at work. Shirley Greyhorse's fictional story also illustrates each of the architectural process steps as another way to explain the role of architectures in a planned environment. Many of the models point to business needs.

Samples of a business model, applications inventory, and proposed technology suite are included as part of the appendixes. The appendixes provide the integration of collaborative efforts across the Department by the Corporate Guidance Group and the Headquarters Collaboration Group to relevant initiatives that form a part of the DOE information architecture.

Chapter 5, Conclusions, outlines some of the cultural observations of the architectures for consideration by organizational elements beginning the architecting process.

The Department, through the outcomes of architectural processes, can complete the detailed business process blueprints and plans to identify critical information needs. This will allow DOE to enter the next century confident that the information technology resources deployed will enable achievement of the Departmental strategic goals, meet legal mandates, and protect and enhance taxpayer investments. 


\section{Credits}

\section{Information Architecture Team}

\author{
Nancy Ahr (DynCorp) \\ David Berkau (HR) \\ Carol Blackston (HR) \\ Brenda Coblentz (HR) \\ Laurie Davis-Covin (DynCorp) \\ Sue Farrand (DynCorp) \\ Kelly Flynn (DynCorp) \\ Connie German (DynCorp)
}

\section{Core Team}

Michael Tiemann (HR)

Robert Kuehne (DynCorp)

Tom Midlam (DynCorp)

Vickie Patterson (DynCorp)

Maura Rehling (DynCorp)

Mary Rozzelle (DynCorp)

O. Sandy Santivanez (DynCorp)

Pat G. Simmons (DynCorp)

Roger Spurzem (DynCorp)

Paula Thompson (DynCorp)

Rusty Wilbur (DynCorp)

\section{Extended Team}

\author{
Susan Genoni (PNNL) \\ Mike Gomez (AL) \\ Charles Guyker (HR) \\ Robert F. Haddad (WPI) \\ Pat Haynes (DP) \\ Pat Heinig (EH) \\ Pirefte Hickey (EEOC) \\ Carol Hunter (LLNL) \\ Rich Jarrell (LMES) \\ Tim Jessen (LLNL) \\ Andy Johnson (WSRC) \\ Susan Johnson (WPI) \\ Sara Jordan (LMES) \\ Catherine Kozlowski (SSDS) \\ Michael Lackner (AlliedSignal) \\ Howard Lewis (HR) \\ Bud Loveall (PANTEX) \\ Ronald MacDonald (ECG, Inc.) \\ Michael Maier (Bechtel) \\ Doug Mann (Battelle) \\ Eric Manuel (NREL) \\ Bob Marshall (LITCO) \\ Mark McKee (AlliedSignal) \\ Meg Milligan (Carlsbad) \\ Annette Mitchell (PANTEX) \\ John O'Brien (SPRO) \\ Greg Parson (ID)
}

\author{
Arnie Peskin (BNL) \\ Robert Peterson (SCIENTECH) \\ Jack Pfister (FNAL) \\ Bob Phillips (Bechtel) \\ Dwayne Ramsey (OAK) \\ Jim Rimmer (AL) \\ Tom Rowlett (HR) \\ John Sewell (CDSI) \\ Steve Simon (EH) \\ Larry Skelly (PNNL) \\ Rodney Slagle (NV) \\ Jeanmarie Smith (EE) \\ Maurice Smith (AlliedSignal) \\ Ruth Ann Smith (DynCorp) \\ R.R. Souther (NV) \\ Brent Stacey (SCIENTECH) \\ Chuck Stafford (TRW) \\ Fred Stanlan (WSRC) \\ Bob Tannert (Galaxy, Inc.) \\ Bruce Thompson (Mitre) \\ Dick Webb (CISA) \\ Diane Weir (LANL) \\ John Wheeler (LMES) \\ Beth Willis (DynCorp) \\ Tim Wilson (IG) \\ Rod Witschey (HR) \\ Andy Yocke (HR)
}

\section{Special Recognition}

The Department of Energy expresses special appreciation to the many Federal Agencies, private corporations, and individuals who have contributed their valuable insights and shared lessons learned related to the evolution and definition of large-scale enterprisewide information architectures. In particular we thank: Steven Spewak, Ph.D. and Stefan DeVocht of Enterprise Architects, Inc., Brian Dickenson of Logical Conclusions, Inc., Bernard Boar, John A. Zachman, and John Kapke for significant contributions to the DOE Information Architecture Program. 


\section{Table of Contents}

\section{Architectural Vision Drivers}

Changing Federal Government $\ldots \ldots \ldots \ldots \ldots \ldots \ldots \ldots \ldots \ldots \ldots \ldots \ldots .1$

Implementing DOE Business Lines Encourages Progress $\ldots \ldots \ldots \ldots \ldots \ldots \ldots .1$

Development of the Information Architecture Program ................

DOE Information Architecture Principles Remain Constant $\ldots \ldots \ldots \ldots \ldots \ldots$. $1-5$

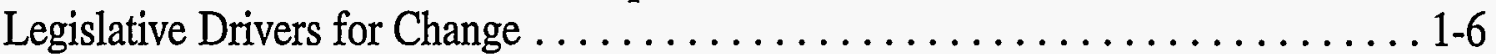

Clinger-Cohen Act. ............................. 1-6

Paperwork Reduction Act $\ldots \ldots \ldots \ldots \ldots \ldots \ldots \ldots \ldots \ldots \ldots . ., 7$

Government Performance and Results Act................. 1-7

Freedom of Information Act (FOIA) Amendments of $1996 \ldots \ldots \ldots \ldots \ldots$. . . . .

Records Management Drives Interoperability Requirements . . . . . . . . . . 1-9

Policy Drivers for Change. ........................... 1-9

Capital Planning and IT Investment Process Complements Architecture . . . . . . 1-11

SIM Process Integrates the Business Subarchitecture . . . . . . . . . . . . 1-11

Information Management Council Supports the DOE Information Architecture. . . . 1-11

Strategic Goals Relate to Information Architecture Conceptual Model . . . . . . . . 1-12

\section{Information Architecture Model Evolution}

Departmental Architecture Program Vision ..................... 2-1

Evolution of the DOE Information Architecture Conceptual Model. . . . . . . . . . 2-1

Value of a Proven Process.............................. 2-4

\section{Departmental Vision}

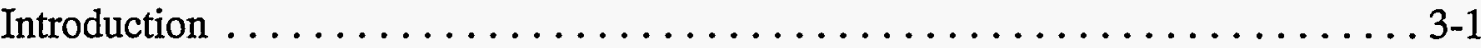

Departmental Enterprise Vision. ......................... 3-2

Linkages Among Architectural Layers. .................. 3-2

Widespread Collaboration . . . . . . . . . . . . . . . . . . . . . . 3-2

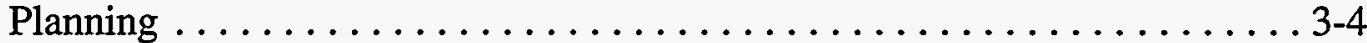

Development and Deployment of Tools and Processes............. 3-4

Education of Business and IT Communities. . . . . . . . . . . . . . 3-4

Site Architects and Site Architectural Processes. . . . . . . . . . . . 3-4

Stewardship................................. 3-5

CIO Support and Endorsement $\ldots \ldots \ldots \ldots \ldots \ldots \ldots \ldots \ldots \ldots \ldots \ldots \ldots \ldots, 5$

Enterprise Vision Drivers. . . . . . . . . . . . . . . . . . . . . 3-6

Business Subarchitecture Vision . . . . . . . . . . . . . . . . . . . 3-7

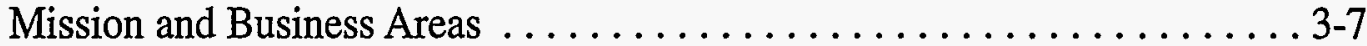

Corporate Management . . . . . . . . . . . . . . . . . . . . . .

DOE Business Context . ............................ 3-9

Composite Business Functions $\ldots \ldots \ldots \ldots \ldots \ldots \ldots \ldots \ldots . . \ldots \ldots$. -9

A User's View . . . . . . . . . . . . . . . . . . .

Business Subarchitecture Drivers. .................. 3-11 
Information and Data Subarchitecture Vision $\ldots \ldots \ldots \ldots \ldots \ldots \ldots$. . . . . . . . .

An Information Model. . . . . . . . . . . . . . . . . . . . . . . . . . . . . . 3-12

Four-Tier Approach to Data Flow . . . . . . . . . . . . . . . . . 3-14

A User's View . . . . . . . . . . . . . . . . . . . . . . . 3-16

Information and Data Subarchitecture Drivers . . . . . . . . . . . 3-16

Applications Subarchitecture Vision . . . . . . . . . . . . . . . . . 3-17

A User's View . . . . . . . . . . . . . . . . . . . . . . . . . . . . . . 3-17

Applications Deliver Business Information . . . . . . . . . . . 3-18

Application Design Characteristics . . . . . . . . . . . . . . . . 3-20

DOE Corporate Systems . . . . . . . . . . . . . . . . . . . . 3-20

Applications Subarchitecture Drivers. . . . . . . . . . . . . . . 3-22

Technology Subarchitecture Vision . . . . . . . . . . . . . . . . $3-23$

A User's View . . . . . . . . . . . . . . . . . . . . . 3-23

Technology Links to All Layers. . . . . . . . . . . . . . . . . . . 3-24

Security and Technology Subarchitecture. . . . . . . . . . . . . 3-25

Security and Technology Subarchitecture Drivers . . . . . . . . . . . 3-26

Technology Suite. . . . . . . . . . . . . . . . . . . . . 3-26

Technology Equals Infrastructure. . . . . . . . . . . . . . . . . 3-28

Technology Subarchitecture Drivers . . . . . . . . . . . . . . . . . 3-29

Standards Vision . . . . . . . . . . . . . . . . . . . . . . . . . 3-30

Technology and Standards Service Areas. . . . . . . . . . . . . . 3-31

Expansion of the DOE Information Architecture Program. . . . . . . . . . . 3-33

\section{Architecture In Action}

Enterprise Architecture Planning. . . . . . . . . . . . . . . . . 4-2

Building the Project . ......................... $4-2$

Role of Architectures . . . . . . . . . . . . . . . . . . . $4-4$

Business and Information Architectures . . . . . . . . . . . . . . 4-5

Value of Business Model . . . . . . . . . . . . . . . . . . . . . . 4-6

Data Architecture . . . . . . . . . . . . . . . . . . . . . . 4-6

Value of Data Architectures. . . . . . . . . . . . . . . . . . . . . 4-8

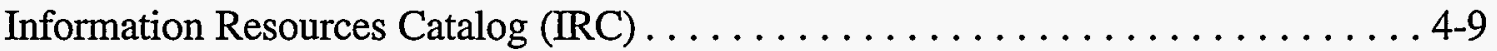

Applications Architecture . . . . . . . . . . . . . . . . . . . . 4-10

Value of Applications Architecture. . . . . . . . . . . . . . 4-13

Technology Architecture . . . . . . . . . . . . . . . . . . . . . . 4-14

Value of Technology Architecture . . . . . . . . . . . . . . . . . . . . . . 4 4-15

Model for Technology Position Statements . . . . . . . . . . . . . . . 4-15

Implementation Plan and Migration Strategy. . . . . . . . . . . . . . 4-17

\section{Conclusions}

Cultural Outcomes of the Architectural Process $\ldots \ldots \ldots \ldots \ldots \ldots \ldots \ldots \ldots$. $\ldots \ldots \ldots$

Recommendations ................................ . . 5-4 
Appendix A - Prototype Business Model

Appendix B - Corporate Applications Inventory

Appendix C - Prototype Technology List

Appendix D - DOE Corporate Guidance

Appendix E - Plan for DOE Headquarters Corporate Systems Architecture

Appendix F - Acronyms

Appendix G - References 
 


\section{List of Figures}

1-1 DOE Information Architecture Program Phases................. 1-4

1-2 Integration of Information Architecture with OMB Policy Guidance . . . . . . 1-10

1-3 DOE Strategic Goals and Information Architecture ............... 1-13

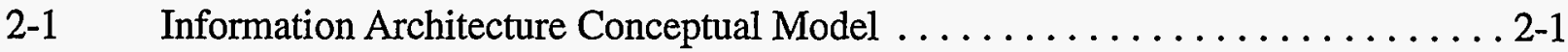

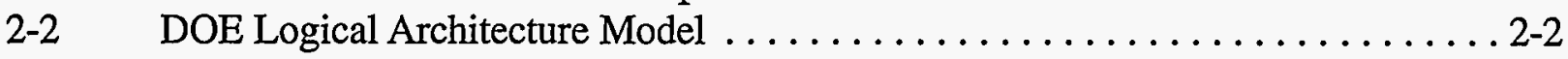

2-3 DOE Architecture Process Model ............................ 2-3

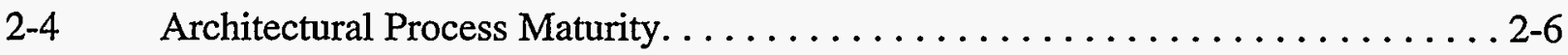

3-1 Departmental Enterprise Vision . . . . . . . . . . . . . . . . . . . . 3-3

3-2 DOE Business Context . ........................... 3-9

3-3 Fundamental and Composite Business Object Definitions . . . . . . . . . . 3-13

3-4 Corporate Systems Share Services ...................... 3-21

3-5 Prototype DOE Technology Planning Scenario $\ldots \ldots \ldots \ldots \ldots \ldots \ldots \ldots .3-28$

3-6 Standards Reference Model .......................... 3-32

4-1 Participants in the DOE Architectural Process . . . . . . . . . . . . . . . . 4-3

4-2 Data Architecture Observation. . . . . . . . . . . . . . . . . . . . . . 4-8

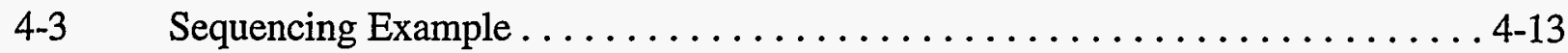

4-4 Challenge of Sequencing ............................... $4-14$

4-5 Summary of Technology Positions....................... 4-16

4-6 Adding Information Planning to Other DOE Planning . . . . . . . . . . . 4-18

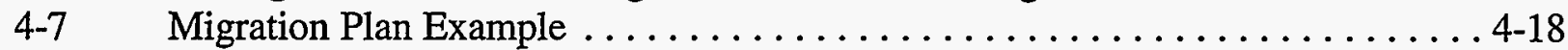

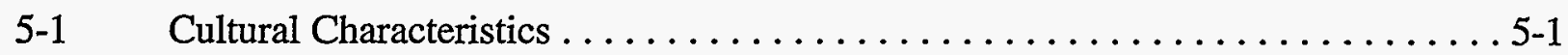

E-1 Headquarters Corporate Architecture Schedule $\ldots \ldots \ldots \ldots \ldots \ldots \ldots$ E-4 


\section{List of Tables}

2-1 Unarchitected and Architected Environments................ 2-5

3-1 Four-Tier Approach to Data Flow . . . . . . . . . . . . . . . . 3-14

3-2 Standards Service/Technology Areas . . . . . . . . . . . . . . . . 3-32

4-1 Business Function/Activity Matrix. . . . . . . . . . . . . . . . . 4-5

4-2 Business Activities to Data Entities Matrix . . . . . . . . . . . . . . . . . 4-7

4-3 Prototype Application Project Matrix and Scoring . . . . . . . . . . . 4-12 



\section{Architectural Vision Drivers}

\section{Changing Federal Government}

Perhaps one of the biggest challenges the Federal Government faces is the current commitment to reducing the Federal budget deficit, requiring each Agency to fulfill its missions and deliver results more efficiently. This economic pressure demands adoption of the best management practices from both the public and the private sector. In the last few years, the President and Congress have enacted laws and policies to reform management throughout the Government. The President and Vice-President initiated the National Performance Review to reinvent Government by focusing on results, service, quality, and customer satisfaction.

\section{Implementing DOE Business Lines Encourages Progress}

To become more cost-efficient and effective, the Department of Energy (DOE) has identified four business lines to utilize and integrate its unique scientific and technological assets, engineering expertise, and facilities. These business lines, shown below, directly affect the security and quality of life of every American citizen. The Secretary of Energy has established priorities for these business lines as follows.

Energy Resources - Enhance U.S. Energy security and develop and deploy clean energy.

National Security - Ensure a safe and reliable nuclear weapons stockpile and reduce the global nuclear danger.

Environmental Quality - Clean up former nuclear weapons sites and find a more effective and timely path forward for disposing of nuclear waste.

Science and Technology - Leverage science and technology to advance fundamental knowledge and our country's economic competitiveness through a stronger partnership with the private sector.

Details on the business lines can be found in the DOE Strategic Plan.

In working towards achieving these goals, DOE has made many changes, resulting in a refocusing of information needs and practices. The following are some of these changes.

The openness initiative and declassification and release of previously close-held information

Privatization and divestiture of DOE assets, such as the Naval Petroleum Reserves 
The Accelerated Strategic Computing Initiative to support simulation of nuclear weapons testing

The development and implementation of an accelerated environmental cleanup strategy

Increased cooperation with the States of the former Soviet Union regarding nuclear weapons

Increased partnership with industry in the Industries of the Future Program

Increased international cooperation in research-related construction, such as the Large Hadron Collider

Reengineering of business processes, downsizing of the workforce, and contract reform initiatives

\section{Development of the Information Architecture Program}

In the midst of these changes, the DOE Information Architecture Program was initiated. DOE and its predecessor agencies had planned, acquired, and implemented information technologies throughout the Department's approximately 50 site locations without comprehensively addressing information requirements of Departmental management, integration of equipment and business processes, duplication of efforts, and corporate information resources. Over the past several years, the Department realized that information management and strategic planning efforts must focus on the utility and management of information, rather than management of technology.

In April 1992, an Information Resources Management Process Improvement Team (IRMPIT) was chartered to facilitate improvement of the Department's information management planning process. The team was tasked with developing a process, driven by program and mission needs and integrated with other Departmental strategic planning processes, to provide infrastructure and support for Departmental information management functions.

The IRMPIT identified the development and implementation of Departmental and programmatic information architectures as key components in the success of a proposed integrated planning process. These architectures should include standards for interoperability and information exchange and establish points of responsibility for the creation, management, and delivery of information. The idea of the Information Management Planning and Architecture Coordinating Team (IMPACT) came from the IRMPIT meetings. 
IMPACT was a volunteer group with representation from most DOE sites and programs. They first met (IMPACT 1) in October 1994 in Idaho Falls, Idaho, to lay the foundation for the DOE information architecture. Subsequent meetings (IMPACT II - V) refined this foundation. A series of documents has been produced, reflecting the evolution of ideas and concepts, as shown in figure 1-1, DOE Information Architecture Program Phases, and explained in the following paragraphs.

Information Architecture Volume I, The Foundations, produced in March 1995, adapted the National Institute of Standards and Technology (NIST) Architecture Model, consisting of five layers (business, information, applications, data, and technology) for use by DOE. The Foundations also established eight vision architecture guiding principles.

Information Architecture Volume II, Baseline Analysis, produced in December 1995, described the current defacto architecture and identified focal areas of management and technical interest. It also provided findings and conclusions to document the challenges to be addressed by the information architecture and established benchmarks against which progress could be measured.

Information Architecture Volume III, Guidance, produced in April 1997, provided a basis for understanding how the Vision architecture will be implemented. The document recommended developing and maintaining information systems in a collaborative and highly networked business environment.

The DOE Information Technology (IT) Standards Program was developed as an integral part of the information architecture. IMPACT I, II, and III meetings defined a standards program and led to the creation of a repository of proposed standards in June 1996. The Information Architecture Standards Adoption and Retirement Process Service Action Plan was published in March 1997. The process was applied to the proposed standards, resulting in the Profile of Adopted Standards, published in September 1997. The subsequent document, the DOE Information Technology Standards Program, Building a Foundation for Information

Management, integrates the DOE standards adoption and retirement process and the resulting standards profile with DOE staff participation in external IT standards activities.

This document, Information Architecture, Volume IV, Vision, presents an architecture target towards which all DOE organizations and activities can aim. The vision of an architected DOE environment incorporates full realization of the architectural principles and fully-developed subarchitecture layers. The purpose of this document is to begin to develop concepts and ideas of the fundamental requirements that will be used in the future building of the DOE information architecture infrastructure. This document also outlines a process for moving towards the vision, employing the Enterprise Architecture Planning (EAP) methodology. 


\section{Figure 1-1, DOE Information Architecture Program Phases}

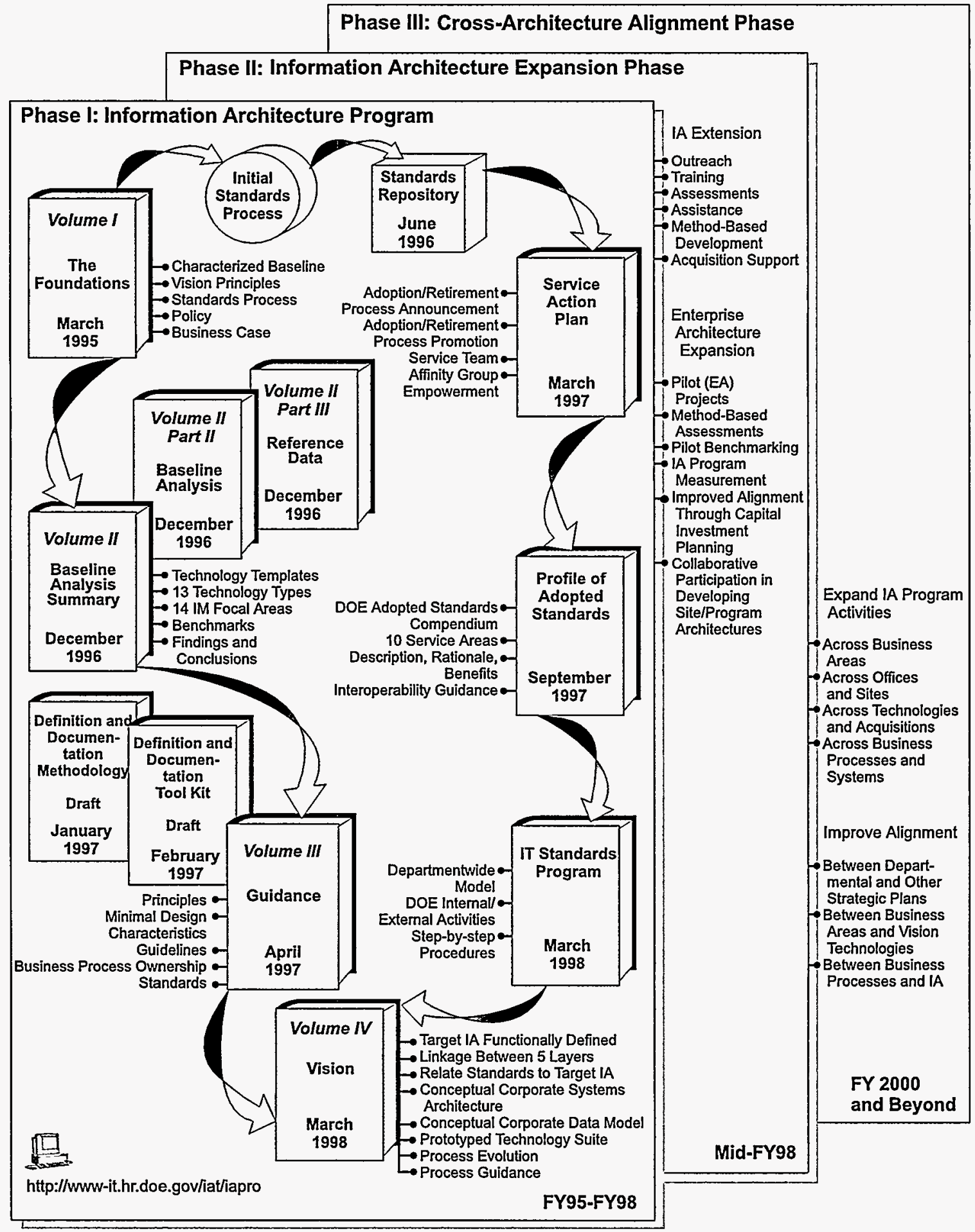


With the publication of this document, Phase I of defining an information architecture program at DOE is complete. Phase $I I$ is the expansion and implementation phase and includes extending the support of the program through the following.

$\square$ Outreach

$\square$ Training

Assessments

\section{Assistance}

Methods-based architecture development

Acquisition support

Benchmarking and measurement

As part of Phase II, pilots using established methodologies will be initiated. The EAP process, already established in the Office of Energy Research, is one methodology that will be further piloted at the corporate, program, or site level. Architecture projects using the EAP methodology, or other rigorous methods, will become the norm throughout the complex. This aspect of Phase II will continue for some time.

When several programs/sites have completed an architecture process, Phase III will begin. Phase III will consist of alignment and integration activities.

\section{DOE Information Architecture Principles Remain Constant}

The DOE Information Architecture Program is based on the principles developed at IMPACT workshops and adopted as DOEwide principles for an architected environment. The principles govern and represent the criteria against which all potential architectural decisions are weighed.

Although DOE has been a constantly changing environment, these principles have withstood the test of time and remain relevant today.

DOE information products are user-centric and customer-driven.

The DOE Information Architecture is based on modular components.

Information architecture is based on an open systems approach.

Security is designed into all architectural elements, balancing accessibility and ease of use with protection of data.

Information is not only a Departmental asset but also a national asset for which DOE's staff is the steward.

DOEwide access to information is the rule rather than the exception. 
$\square$ The information architecture incorporates a robust interface that optimizes the nature, efficiency, and effectiveness of the human operator.

$\square$ DOE will have an information technology infrastructure that links offices, programs, facilities, and field locations together seamlessly.

As the architectural processes are executed by programs and sites, the principles are reaffirmed, modified, and augmented by program or site-specific principles. The principles guide the evolving architecture towards the vision. When the vision is realized, the adherence to the principles should be complete.

\section{Legislative Drivers for Change}

Recent legislation underscores an increased commitment to proactive management of Governmental information resources.

$\square$ Clinger-Cohen Act of 1996

$\square$ Paperwork Reduction Act of 1995

$\square$ Government Performance and Results Act (GPRA) of 1993

$\square$ Freedom of Information Act (FOIA) Amendments of 1996

These legislative drivers, described in detail in the following paragraphs, provide an impetus for implementing an information architecture.

\section{Clinger-Cohen Act}

The Clinger-Cohen Act (Information Technology Management Reform Act) established the duties of the Agency Chief Information Officer (CIO). This Act requires that the head of each Agency establish an effective and efficient capital planning and investment control process for selecting, managing, and evaluating major IT investments, and prescribes minimum requirements for these processes.

The responsibilities of the head of the Agency include the following.

Ensure all IT investments deliver substantial business benefit to the Agency and/or a substantial return on investment (ROI) to the taxpayer

Ensure a capital planning process is established and rigorously used to define and validate all IT investments

Be accountable for and have final authority over continuation or termination of all IT investments 
$\square$ Prepare an annual report, to be included in the Agency's budget submission to Congress, on the progress in achieving goals

The CIO is responsible for the following.

Provide advice and assistance to the head of the Agency and other senior Agency officials to acquire and manage IT

Develop, maintain, and facilitate the implementation of a sound and integrated IT architecture for the Agency, through the capital planning process

Monitor and evaluate the performance of IT programs of the Agency and advise the Agency head whether to continue, modify, or terminate a program or project, through the capital planning process

Establish a board of senior level managers to make key business and funding decisions on IT investments

\section{Paperwork Reduction Act}

The Paperwork Reduction Act specifically targets the Information Resource Management (IRM) function by requiring agencies to do the following.

$\square$ Develop and maintain a strategic IRM plan that describes how IRM activities help accomplish Agency missions

Maintain a current and complete inventory of the Agency's information resources

$\square$ Ensure that IRM operations and decisions are integrated with organizational planning, budgeting, financial management, human resources management, and program decisions

Develop a full and accurate accounting of IT expenditures, related expenses, and results

Establish goals for improving IRM contributions to program productivity, efficiency, and effectiveness; methods for measuring progress towards those goals; and clear roles and responsibilities for achieving the goals

\section{Government Performance and Results Act}

The GPRA requires Agencies to do the following.

Focus on program outcomes

Establish measurable annual objectives that link to long-term goals 
Develop budgets based on planned performance

Report results

Key vehicles to implementing this legislation are the multi-year strategic plan, performance plans for each program activity identified in the budget, and annual performance reviews that compare actual performance to the annual goals established in the performance plans.

\section{Freedom of Information Act (FOIA) Amendments of 1996}

Congress has enacted a number of changes to the original Freedom of Information Act (FOIA) concerning electronic records and Agency obligations.

Agency records maintained in electronic format are subject to the FOIA.

Requesters may request records in a specific form or format, and the agency must provide the records in the format requested, including a particular electronic format, "if the record is readily reproducible by the Agency in that form or format."

Agencies must make "reasonable efforts to search for the records in electronic form or format."

Currently, Agency materials that are published in the Federal Register must be made available online by the Government Printing Office. The changes to the FOIA expand the types of Agency records that must be made available online, including the following.

- Opinions from Agency adjudications, interpretations adopted by the Agency but not published in the Federal Register, staff manuals and instructions to staff that affect the public, if these materials were created after November 1, 1996. In accordance with the FOIA Amendments of 1996, Departmental records required to be in FOIA reading rooms and created on or after November 1,1996 , must be made available in electronic format (e.g., CD-ROM, disk).

- Records identified by previous requests that have been requested, or are likely to be requested again, if the records were created after November 1,1996 . In addition, the Agency must have an online general index of these records available by December 31 , 1999.

Other laws, which are also legislative drivers, are not addressed in this document. Please refer to the list of other drivers found in Information Architecture, Volume III, Guidance. 


\section{Records Management Drives Interoperability Requirements}

The Openness Advisory Panel (OAP) was formed to advise the Secretary of Energy's Advisory Board (SEAB) on how to improve the de-classification process to enhance openness to DOE information. The OAP issued a report in September 1997 that stated openness could be improved by gaining "intellectual control" over unclassified as well as classified records. It was recommended that automation be used to achieve this control via converting records to digital form and developing computer systems to support document management and records management practices, where practicable. Thus, the development of information architecture at DOE should include OAP goals. Document control and records management systems developed at DOE must have the interoperability necessary for easy and comprehensive access to DOE information.

\section{Policy Drivers for Change}

The Office of Management and Budget (OMB) issued a policy statement in October 1996 from Franklin D. Raines citing the Clinger-Cohen Act as the legal mandate for formulating effective long-term Agency strategies that provide multi-year plans for achieving mission goals. Such long-term plans are in accordance with the GPRA. The OMB policy sets forth eight critical considerations for making acquisition decisions, in addition to "architectures which integrate Agency work processes and information flows with technology to achieve the Agency's technology vision..."

Investment supports DOE missions

No alternative can efficiently support the function

Investment supports work processes that have been reengineered

ROI is better than other use of funds

Investment supports the DOEwide information architecture

Use of custom-designed components is minimized and commercial-off-the-shelf products maximized

Implementation is modularized

Ácquisition strategy is effective and efficient 
The DOE architectural process, when integrated with the OMB policy statement (which fundamentally represents a group of best business practices), provides one means for Departmental compliance with the Clinger-Cohen Act. Figure 1-2 illustrates the integration of the DOE architectural process with the eight policy considerations from the OMB policy statement.

Figure 1-2, Integration of Information Architecture with OMB Policy Guidance

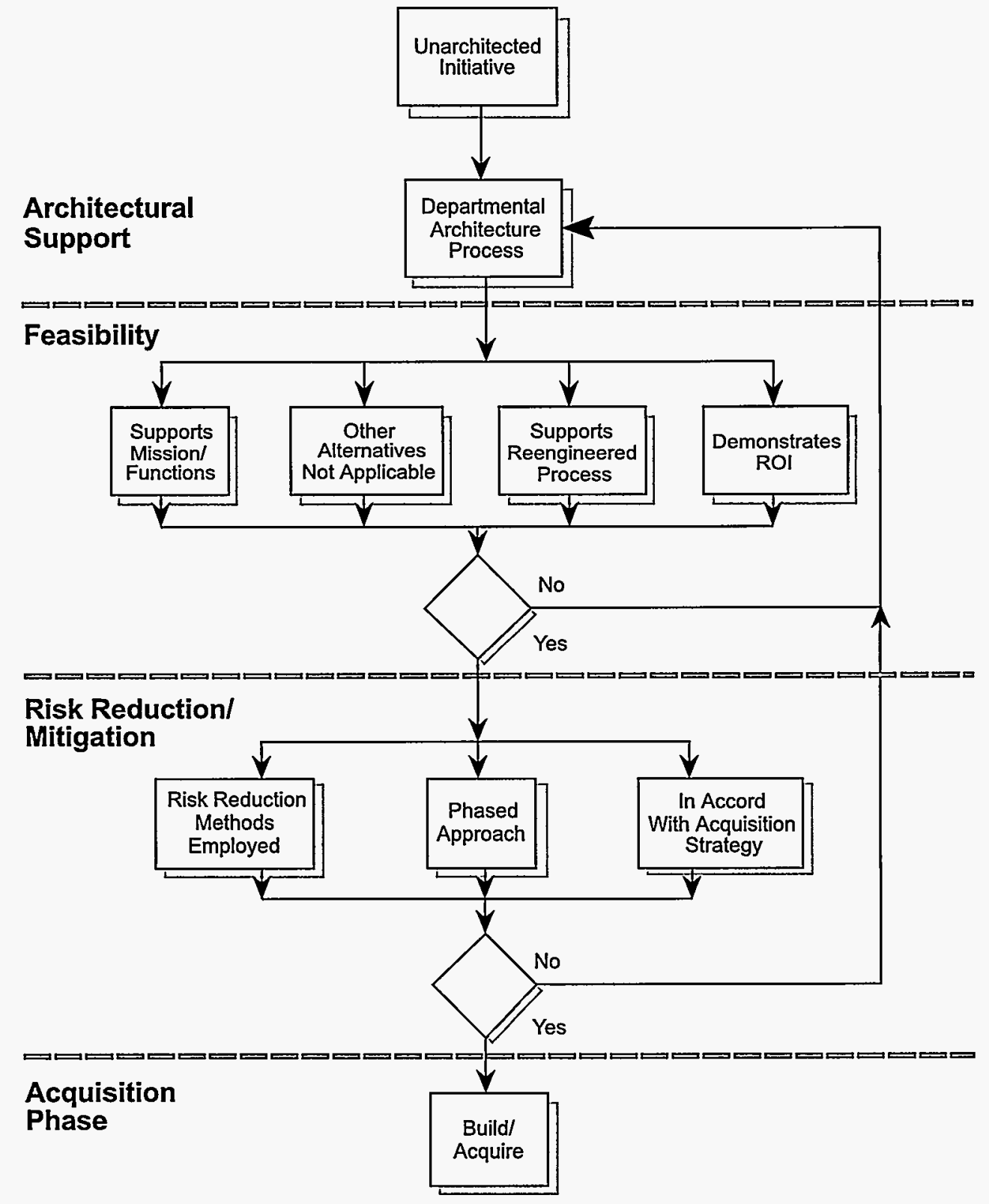




\section{Capital Planning and IT Investment Process Complements Architecture}

The Clinger-Cohen Act tasks Federal Agencies with establishing a capital planning and IT investment process. The purpose of the process is to recognize expenditures in information technology as business investments that require the business manager's attention. DOE has established the Executive Committee on Information Management (ECIM), comprising the heads of the DOE programs, as the DOE Corporate IT Investment Board. The DOE CIO is the Executive Secretary of the ECIM, and the Deputy Secretary is the Chairman. This group makes decisions about major IT projects in the DOE IT Investment Portfolio. The group selects investments for the portfolio, monitors and controls the implementation of the investments, and evaluates the investment successes in a post implementation review.

\section{SIM Process Integrates the Business Subarchitecture}

DOE began use of the Strategic Information Management (SIM) process in Fiscal Year (FY) 1996. Based on General Services Administration (GSA) Best Practices, the SIM process is a rigorous process for developing business cases for the DOE IT Investment Portfolio. The process consists of five steps: mission validation and performance measures review, business process analysis, business decision definition, information needs identification, and information systems assessment. Also included is an analysis of benefits and costs. SIM is applied to all corporate systems and major information systems. What SIM lacks is an overall analysis of business needs at the enterprise level, as presented later in this document; however, it assures that individual investments align with the corresponding business function.

\section{Information Management Council Supports the DOE Information Architecture}

The DOE Information Management Council is made up of information management (IM) representatives from DOE programs at Headquarters and operations offices in the field. Late in FY 1996, the Council tasked its program office representatives with forming a subcommittee to issue planning guidance to the field sites. The thrust of this tasking was to develop, through consensus, useful and sound corporate information management guidance. This subcommittee is called the Corporate Guidance Group (CGG) and the product of their consensus process is a set of Corporate Guidance Items, found in appendix D. In addition to issuing a guidance item recommending that DOE Elements budget for information architecture efforts, the group has become part of the information architecture standards adoption and retirement process. 
As an outgrowth of the cooperative spirit engendered by the CGG, the Headquarters Collaboration Group (HCG) was formed. The HCG consists of IM managers from each program. Members have funding authority, or represent those who do, and represent the interests and missions of their respective programs. They collaborate on projects of mutual concern and benefit. Once projects have been identified, they are prioritized by weighing the benefits against the risks. Costs are allocated among the members for projects chosen for the year. The HCG meets throughout the year to monitor progress on priority projects and to deliberate the merits of proposed initiatives.

A Special Integration Project (SIP) team provides support for the operation of the HCG and the CGG. In addition, the team provides a coordinated and dedicated focus on IM planning, guidance, and architecture. The SIP team also works closely with the DOE Information Architecture Program Manager to ensure that appropriate tools and processes are developed to facilitate integration of HCG and CGG initiatives into the Departmental architectures.

The Departmental Information Architecture Review Board (DIARB) documents input to the capital planning and IT investment process by determining the degree of architectural alignment of proposed initiatives to mitigate risk. It serves as a steering body to ensure that future information architecture initiatives align with Strategic Plan goals that support the mission functions of the Department. The DIARB also serves in a prereview functional capacity to support the Information Management Council regarding Departmentwide architectural issues.

\section{Strategic Goals Relate to Information Architecture Conceptual Model}

The DOE 1997 Information Management Strategic Plan (IMSP) establishes a shared IM vision for the various elements of DOE. Developed through consensus of the DOE Federal IM community, the IMSP serves as a blueprint for strategic information management direction. The IMSP establishes six goals. These goals are centered around the five layers of the architecture. Figure 1-3, DOE Strategic Goals and Information Architecture, illustrates the relationship of the IMSP goals to the DOE Information Architecture Conceptual Model. 


\section{Figure 1-3, DOE Strategic Goals and Information Architecture}

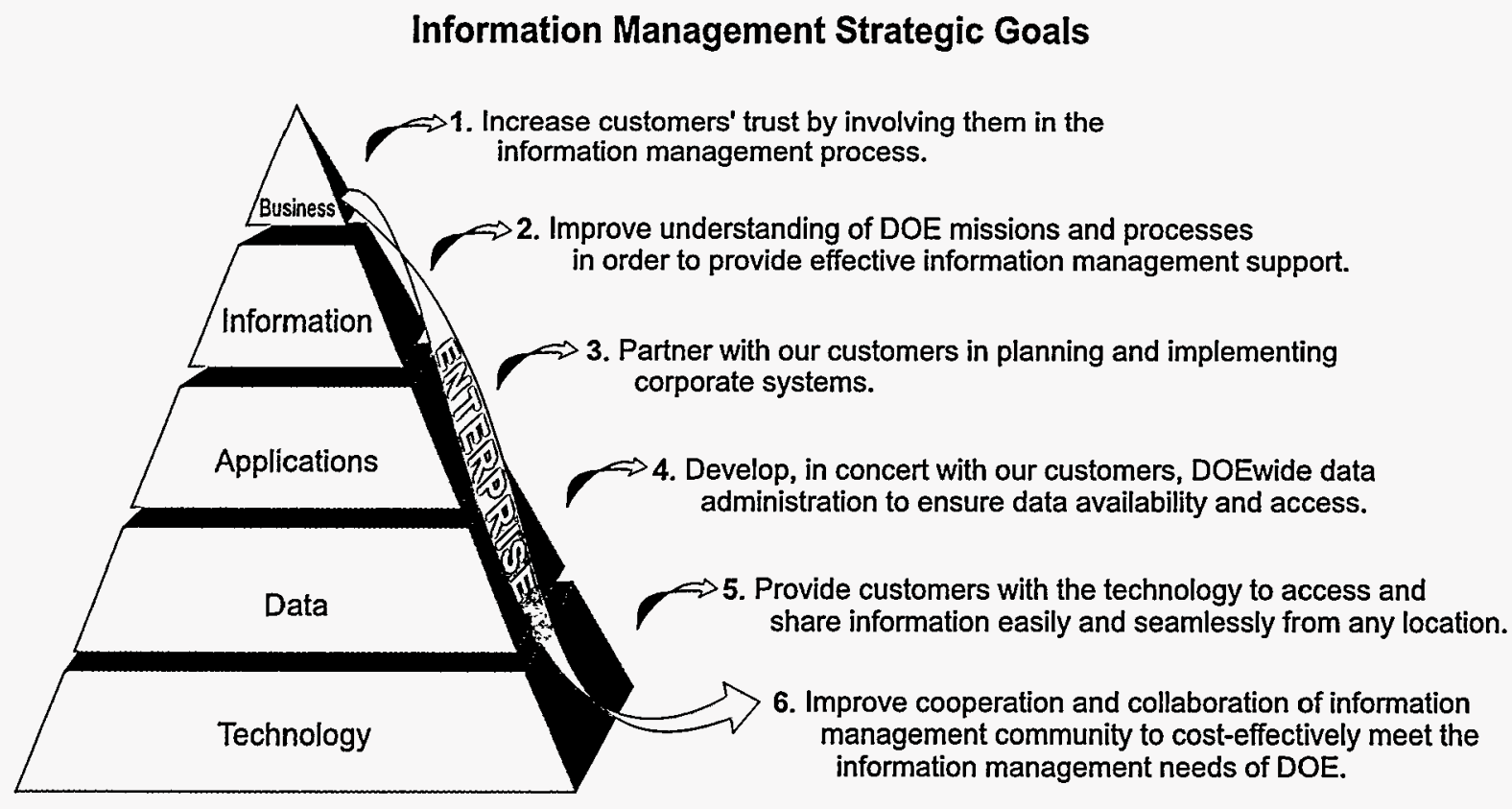

DOE Information Architecture

Collaboration and cooperative support are crucial to achieving Departmental and information management strategic visions. The information management community will use an integrated, complexwide framework for planning, budgeting, evaluating, and implementing information management solutions to accomplish DOE missions. Teaming with stakeholders and customers to implement corporate solutions ensures that resources are adequately budgeted, funded, and allocated to promote resource sharing.

The DOE environment is dynamic and will continue to evolve. Some changes are unexpected and happen quickly; the DOE information architecture must be flexible to handle these shifts in direction. Other changes are planned; therefore, the architecture must be robust enough to progress according to plan. Information architecture provides a framework for the achievement of a vision. 


\section{Information Architecture Model Evolution}

\section{Departmental Architecture Program Vision}

Department of Energy (DOE) decision makers, staff members, customers, and partners will receive quality and timely information products and services, employing an architected information systems environment that supports business-driven needs. An ongoing process for architectural support, with continuous involvement of the DOE business and information technology community, will deliver cost-effective and highly acclaimed solutions.

\section{Evolution of the DOE Information Architecture Conceptual Model}

The DOE Information Architecture Conceptual Model (figure 2-1) consists of five interrelated architectural layers. This conceptual model provides a high-level view of how business needs, information, applications, data, and technology interrelate.

Figure 2-1, Information Architecture Conceptual Model

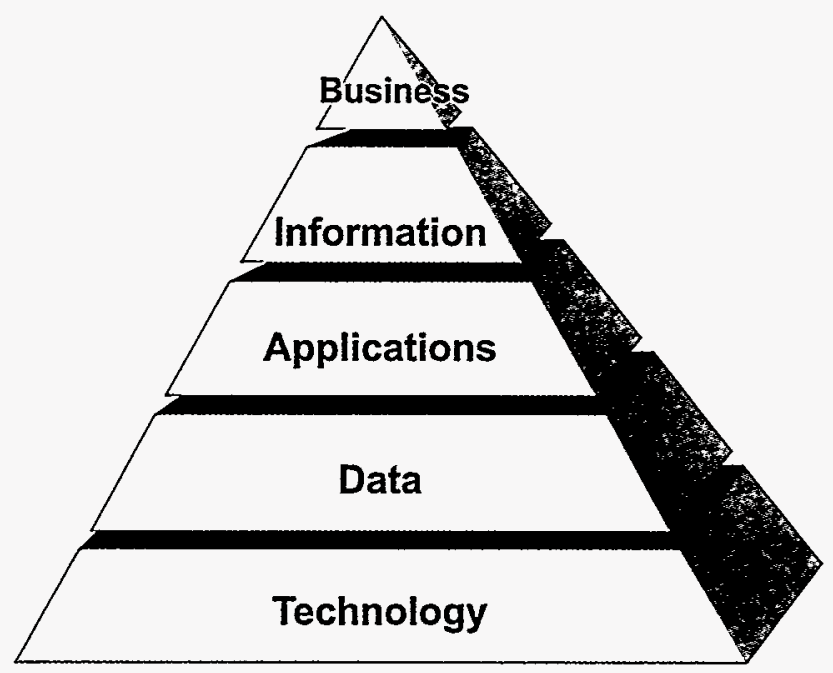

The DOE Information Architecture Conceptual Model evolves to a logical model (figure 2-2), which expresses needs downward and returns results upwards through the layers. The logical model reorders the layers of the DOE Information Architecture Conceptual Model so that the layers become interdependent upon process activities that support orderly migration planning. Planning input is provided for meeting business needs through migration plans for information technology development and implementation. 
The logical model reorders the layers to demonstrate that applications rely on technology, that data is provided through applications (without being embedded within them), and that the intersection of data points provides information to service business needs. The logical model has an architectural lifecycle consisting of four elements: architectural input at each layer of the model, a migration plan and strategy, development/implementation of applications and technology, and deployment. The corollaries to the elements of the lifecycle are structure, order, progression, and assimilation.

\section{Figure 2-2, DOE Logical Architecture Model}

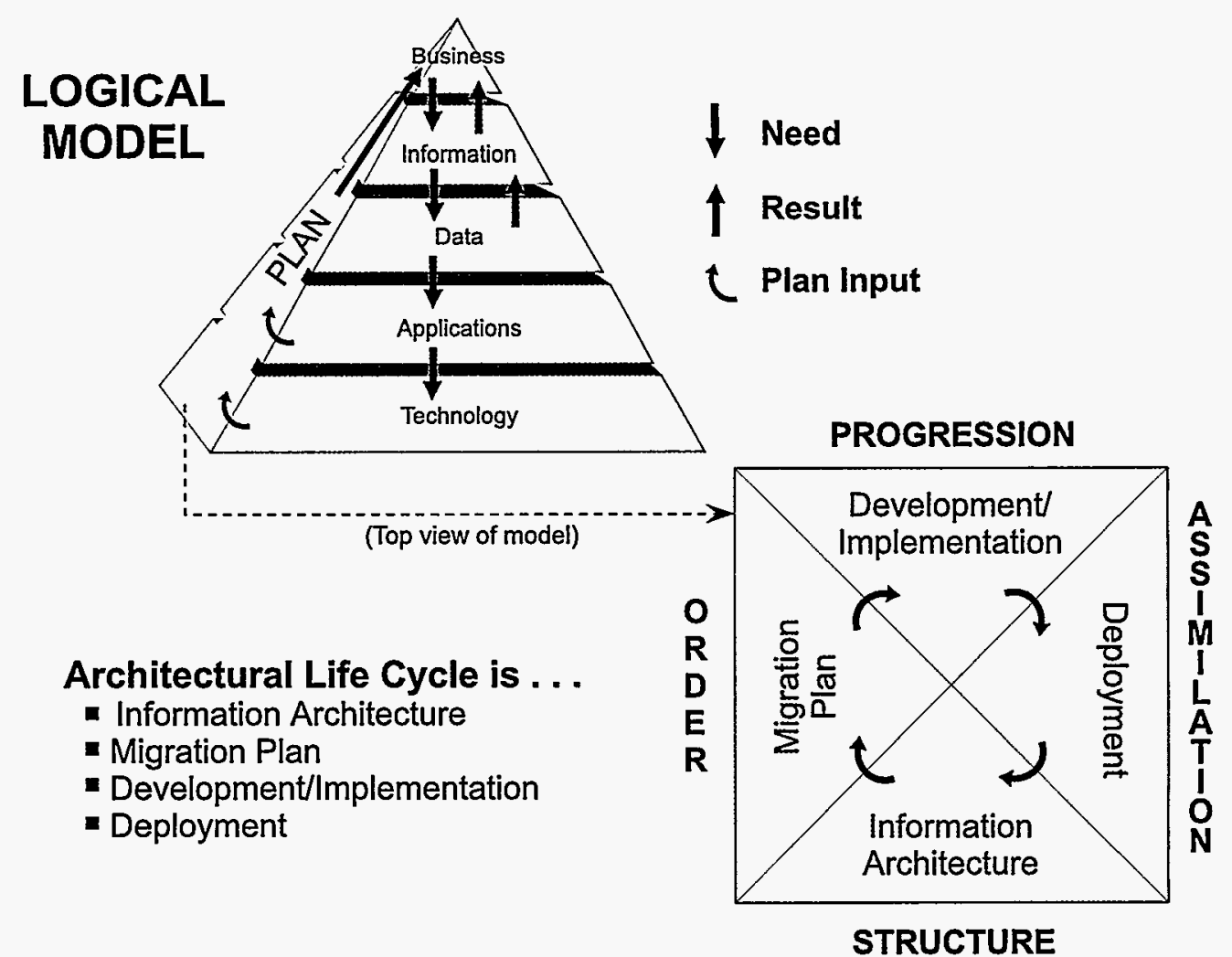

The DOE Logical Model evolves to a process model (figure 2-3), which interrelates the five layers to the structured Enterprise Architecture Planning (EAP) process. The EAP model was developed and is provided courtesy of Steven H. Spewak, Ph.D., of Enterprise Architects, Inc.

In the process model, business needs are expressed through the business model, while rules in the form of scope definition, principles, and a vision for the organization drive the context of the EAP process. The Information Resources Catalog contains the existing applications and technology baseline. Definition of the data, applications, and technology architecture results from the delta between known business needs and existing applications and technology. The migration plan results from a meshing of interdependent needs (for applications and technology) that must be implemented to support the business model. 
Figure 2-3, DOE Architecture Process Model

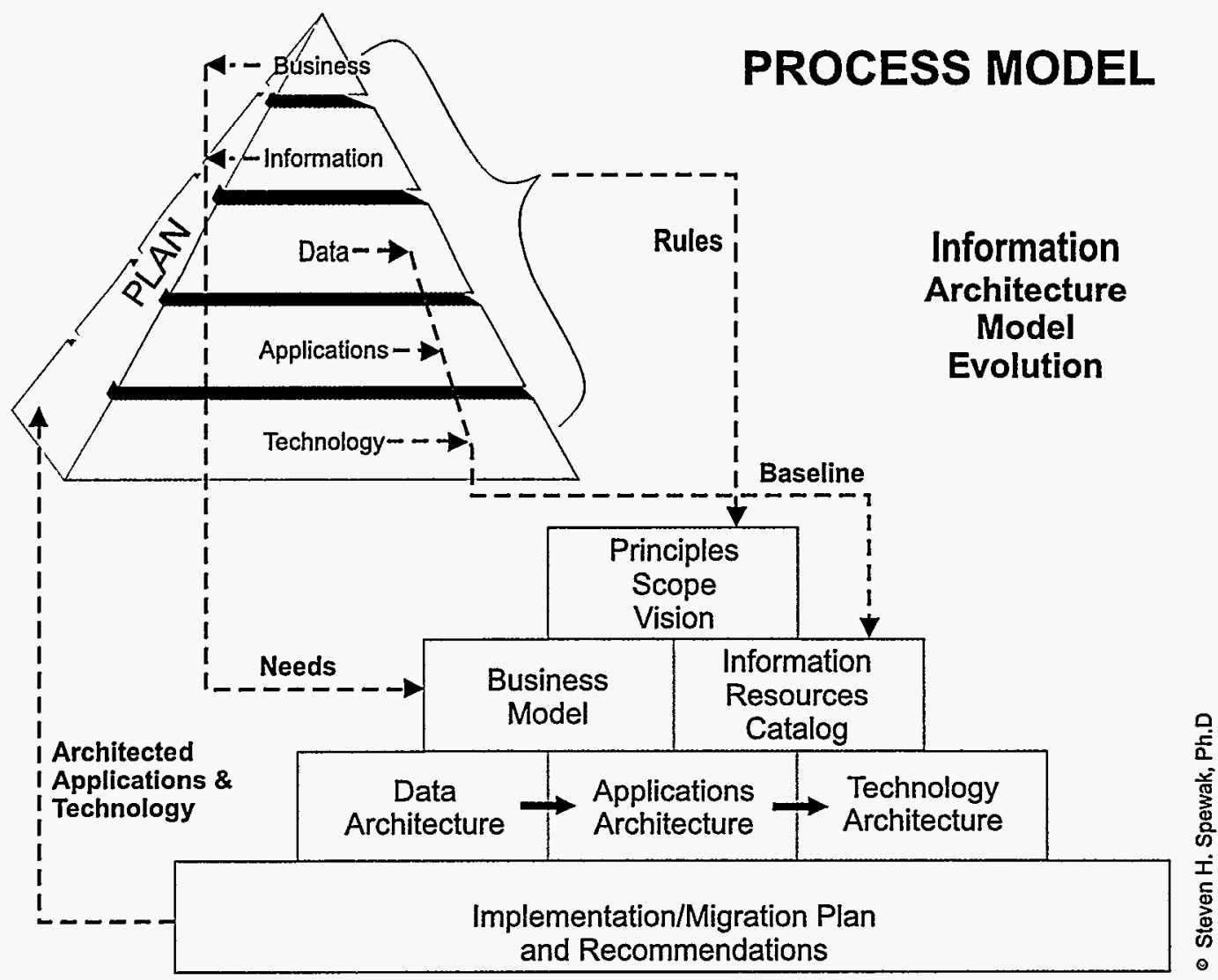

ENTERPRISE ARCHITECTURE PLANNING (EAP)

This process serves as one example of how the DOE five-layer model maps to a representative process. The vision architecture recognizes other available processes that could map to the DOE five-layer model. A notable example is the Information Systems Architecture (ISA) Framework, ${ }^{1}$ first published in the IBM Systems Journal in 1987.

This Vision document extends the guidance published in Information Architecture, Volume III, Guidance, by providing a detailed process description for site enterprise architecture, and advocates a repeatable ongoing process for each site.

1 Zachman, John A., A Framework for Information Systems Architecture, IBM Systems Journal, September 1987. This classic work describes the framework used in most information architecture models and clarifies the distinctions among three types of architectures: data, process or application, and technology. 


\section{Value of a Proven Process}

For any organization employing an ongoing process for architectural support, there are several benefits.

Business-based process for making information management decisions

Data, applications, and technology architectures that support the business model

Measurable results

Repeatable and scalable process to develop compatible architectures

Information systems technology and applications projects of manageable size and complexity

$\square$ Justifiable information management budgets

$\square$ Plan for orderly divestiture of older technologies

- Clear plan for moving forward to meet business needs through a defined architectural process

Group process and organizationwide buy-in are hallmarks of an architected, principle-based technology environment. As business leaders identify the data needed to accomplish their work, they discover many similarities in business functions across the organization. This realization begins the culture change of an architected environment that is reinforced frequently as the architectural process continues. As a result of the process, a migration plan is produced along with a robust set of recommendations. This fundamentally alters the way information management decisions are made to support the organization. The recommendations include the functions that must be reengineered to support business-driven architectures.

Without a defined process, a coordinated architecture that fully supports the business needs of the organization cannot exist. Table 2-1 shows the organizational manifestations of unarchitected and architected environments. 


\begin{tabular}{|c|c|c|}
\hline \multicolumn{3}{|c|}{ Table 2-1, Unarchitected and Architected Environments } \\
\hline Organizational Objectives & Unarchitected & Architected \\
\hline Timely Access to Data & Pockets Without Consistency & $\begin{array}{l}\text { Consistent Across the } \\
\text { Organization }\end{array}$ \\
\hline $\begin{array}{l}\text { Adaptable to Changing } \\
\text { Business }\end{array}$ & Inflexible & Flexible \\
\hline Accurate and Consistent Data & Varies from System-to-System & Consistent Enterprisewide \\
\hline Data is Shared & Parochial, Stovepiped Systems & All Systems Interface \\
\hline $\begin{array}{l}\text { Information Systems (IS) } \\
\text { Decisions are Planned }\end{array}$ & Without Wide Buy-in & With Wide Buy-in \\
\hline $\begin{array}{l}\text { Development Environment } \\
\text { Employs Consistent } \\
\text { Methodology }\end{array}$ & $\begin{array}{l}\text { Inconsistent, Chaos Rules, No } \\
\text { Methodology }\end{array}$ & $\begin{array}{l}\text { Consistent and Predictable, } \\
\text { Process and Methods Based }\end{array}$ \\
\hline Containment of IS Costs & Unpredictable & Predictable/Justifiable \\
\hline $\begin{array}{l}\text { Customer Service } \\
\text { Improvements }\end{array}$ & Not measurable & Measurable \\
\hline $\begin{array}{l}\text { Management/Business } \\
\text { Representative Participation }\end{array}$ & $\begin{array}{l}\text { Uninvolved, Systems Fall Short } \\
\text { of Expectations }\end{array}$ & $\begin{array}{l}\text { Systems Meet Expectations, } \\
\text { Credible Business Perspective }\end{array}$ \\
\hline Information is an Asset & Unrecognized & Recognized and Leveraged \\
\hline Records Management & $\begin{array}{l}\text { Records Commingled and } \\
\text { Indistinguishable. Non-standard } \\
\text { Formats. Inconsistent } \\
\text { Metadata. }\end{array}$ & $\begin{array}{l}\text { Records Captured, Uniformly } \\
\text { Organized in Standard } \\
\text { Formats, Migrated to } \\
\text { Appropriate Storage. }\end{array}$ \\
\hline
\end{tabular}

Without a proven architectural process, duplication of efforts, stovepiped systems, and excess costs proliferate in the day-to-day business of the organization. There is a lack of clear direction, no sense of order, and little discipline in deployment of technology. Processes are not repeatable or scalable and lack the underpinnings of methodical approaches. 
The desired results of information technology deployment are contrasted to the maturity of the architectural process as depicted in figure 2-4. As architected applications and technology are planned and deployed, the organization gains expertise in using architectural processes. As processes are rolled out and technology is deployed, efforts are concentrated in the upper right quadrant, in which fully-architected applications and technology, desired for meeting business needs, are found.

Figure 2-4, Architectural Process Maturity

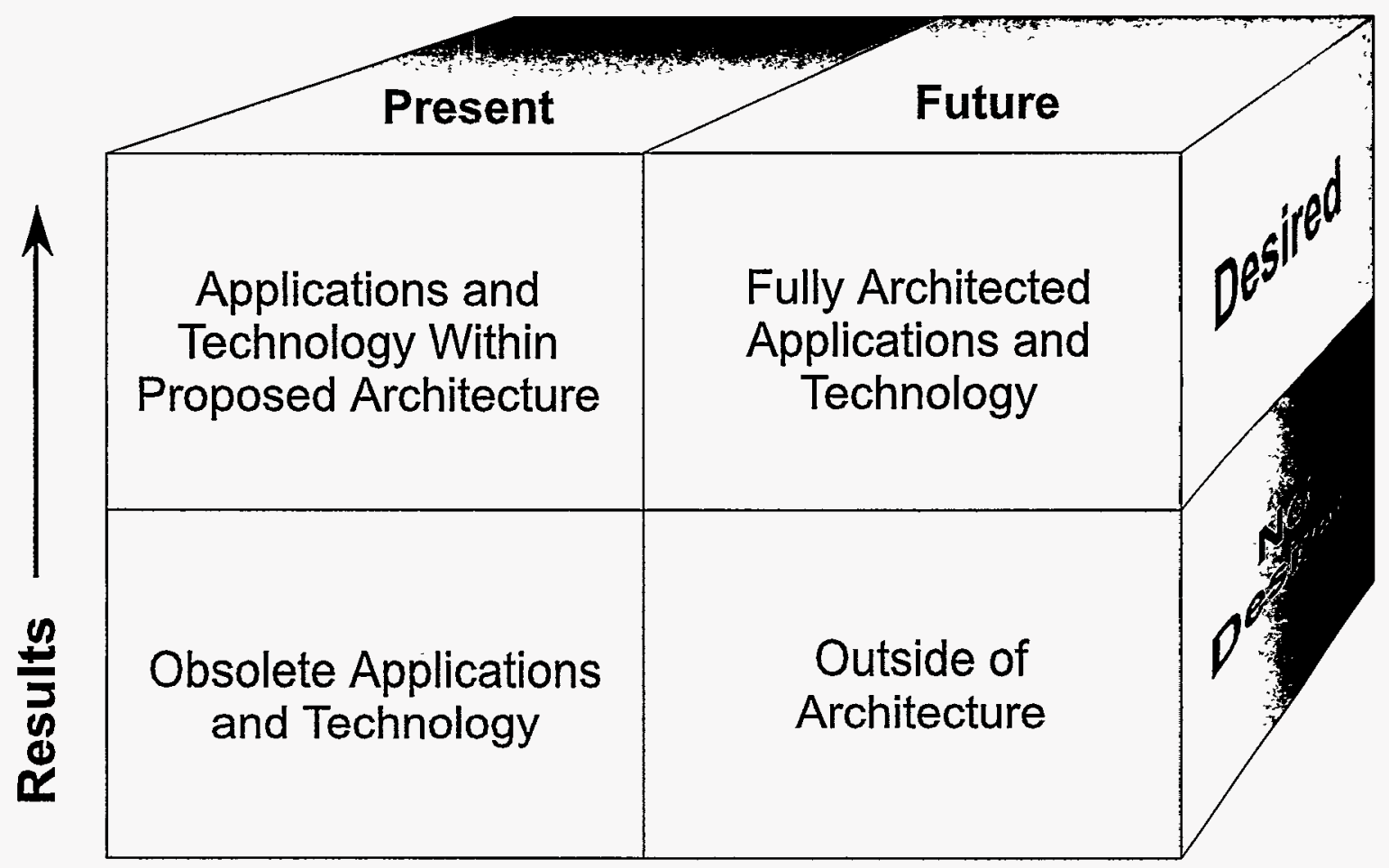

\section{Architectural Process Maturity}




\section{Departmental Vision}

\section{Introduction}

"I keep six honest serving-men (They taught me all I knew); Their names are What and Why and How and Where and When and Who."

—Rudyard Kipling, The Elephant's Child

Vision is the first servant of the organization, the what. Vision provides strategic direction. Without vision, the activities-why, how, where, when, and who-are conducted in a chaotic manner. A framework for architectural definition employs and reflects Kipling's six honest serving-men. The first task is to identify what must be done to serve the organization's strategic needs. This identification process is the development of a vision.

During the Information Management Planning and Architecture Coordinating Team (IMPACT) IV meeting, working groups developed vision statements based upon the Information Systems Architecture (ISA) Framework, ${ }^{2}$ for the Department of Energy (DOE) enterprise and each layer of the DOE Information Architecture Conceptual Model. The enterprise and subarchitecture vision statements in this chapter separate the vision (what) from the means for achieving full architectural definition and implementation within the layers.

\section{WHAT}

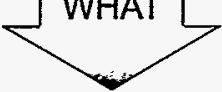

\begin{tabular}{|c|c|c|}
\hline $\begin{array}{c}\text { DOE } \\
\text { Information } \\
\text { Architecture } \\
\text { Conceptual Model }\end{array}$ & Information Architecture Vision & $\begin{array}{c}\text { Information Systems } \\
\text { Architecture } \\
\text { Framework }\end{array}$ \\
\hline $\begin{array}{c}\text { Departmental } \\
\text { Enterprise }\end{array}$ & Departmental Enterprise Vision & Scope \\
\hline Business Layer & Business Subarchitecture Vision & Enterprise Model \\
\hline Information Layer & Information Subarchitecture Vision & System Models \\
\hline Data Layer & Data Subarchitecture Vision & Components \\
\hline Applications Layer & Applications Subarchitecture Vision & Functioning Systems \\
\hline Technology Layer & Technology Subarchitecture Vision & Technology Model \\
\hline
\end{tabular}

2 Zachman, John A., A Framework for Information Systems Architecture, IBM Systems Journal, September 1987. This classic work describes the framework used in most information architecture models and clarifies the distinctions among three types of architectures: data, process or application, and technology. 


\section{Departmental Enterprise Vision}

The Department's decision makers, staff, customers, and partners will be provided with quality and timely information products and services that support business and customer needs. The architected environment will be capable of continuous adaptation and change. Our diverse and geographically dispersed users are empowered to devise and implement interoperable applications, which exchange appropriately safeguarded information, with our partners and stakeholders. This vision will meet the goals and objectives of the DOE Strategic Plan through the five-layer DOE Information Architecture Conceptual Model.

The Departmental Enterprise Vision will be fulfilled through a variety of initiatives.

Linkages among the architectural layers

$\square$ Widespread collaboration

$\square$ Migration planning and integration with higher level plans

Development and deployment of tools and processes

Education of both the business and the information technology (IT) community

Institution of site architects and site architectural processes

Stewardship

$\square$ Chief Information Officer (CIO) support and endorsement

\section{Linkages Among Architectural Layers}

The interdependence among the five layers of the DOE Information Architecture Conceptual Model, when coordinated through an Enterprise Architecture Planning (EAP) process, produces the necessary linkages to ensure that business and information needs are being met through applications that serve the right data. The technology layer is the foundation upon which the other four layers depend, but it is driven by the business needs of the organization. The vision is that the linking process is ensured through the use of an architectural process that adequately addresses each of the architectural layers.

\section{Widespread Collaboration}

Collaboration is currently provided through the Information Management Council, Corporate Guidance Group (CGG), Headquarters Collaboration Group (HCG), Strategic Information Management (SIM) process, and Special Integration Project (SIP). The vision of collaboration is that sharing of lessons learned and informal collaboration will increase the use of best practices, methods, and processes. Informal collaboration occurs as more sites and programs become architecturally aligned. Formal collaboration will take on more meaning as the collaborative groups gain an understanding of the architectural process and new initiatives are undertaken. 


\section{Figure 3-1, Departmental Enterprise Vision}

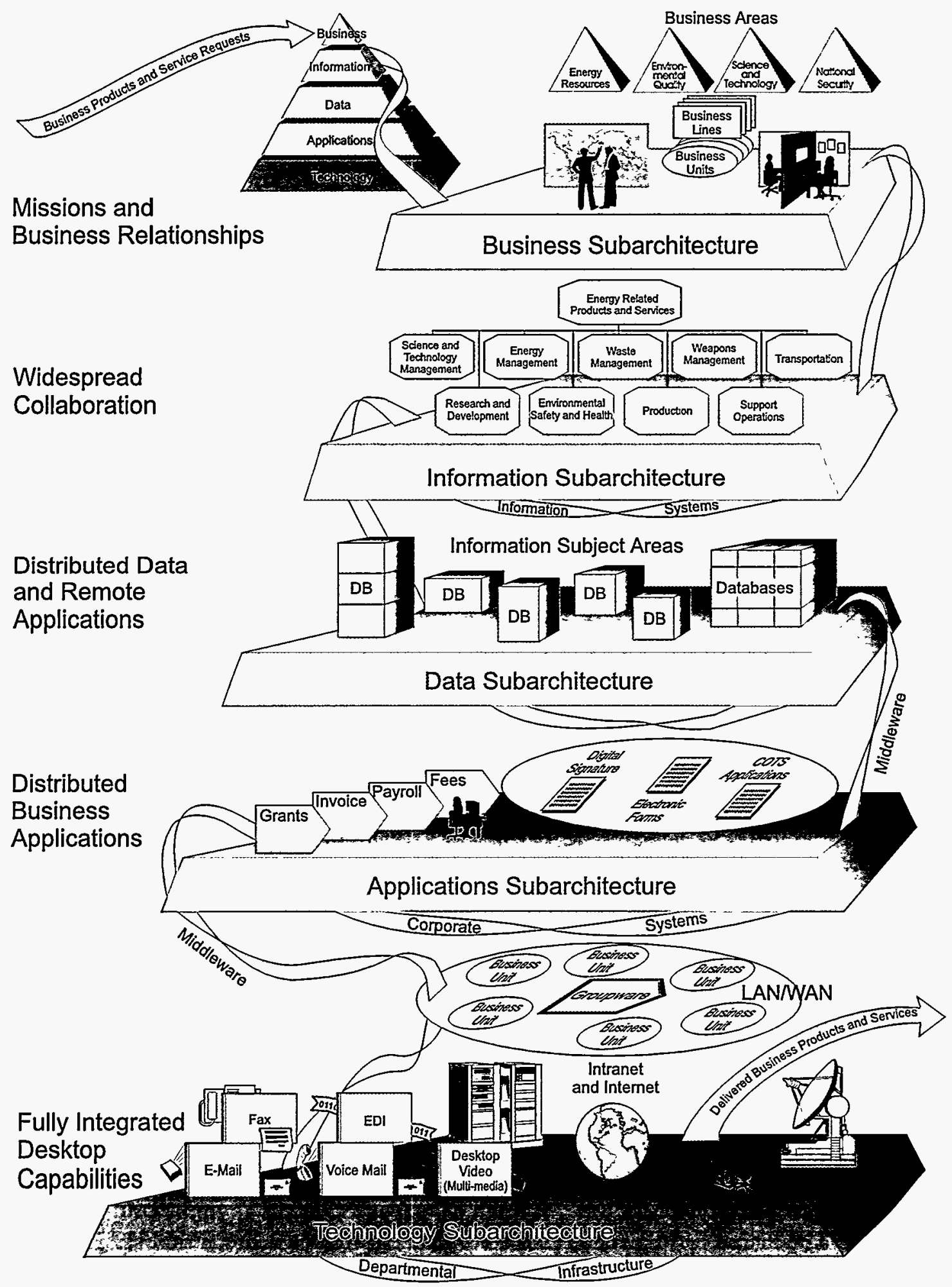




\section{Planning}

As sites begin to develop individual migration plans that move them towards architected environments, linkages to higher level plans, such as the DOE Strategic Plan and the Information Management Strategic Plan, will become more apparent and more important. Planning is also considered in the Capital IT Investment process described in chapter 1, Architectural Vision Drivers. The initiatives exposed to the rigors of this process will become architecturally driven rather than technology-driven due to a greater emphasis on meeting business needs and long-term strategic goals.

\section{Development and Deployment of Tools and Processes}

Development and deployment of architectural tools and processes will assist in the development of aligned architectures. The tools and processes currently envisioned include the following.

Architectural Web sites

Architectural score cards

Common data dictionary

Business and data models

$\square$ Applications and technology catalogs

$\square$ Process models and descriptions

Research into inhouse and commercial-off-the-shelf (COTS) toolsets is ongoing. The vision for development and deployment of architectural tools and processes is that the availability of tools and processes to all segments of the DOE community fosters measurable results of executed architectural processes.

\section{Education of Business and IT Communities}

Because of the close relationship between IT initiatives meeting business needs, an education program is needed. Such a program would foster greater appreciation of business problems by information technologists and understanding of the architecture process by business representatives. The educational vision includes course offerings for both business and IT representatives to provide common understanding and leverage of the architectural process to the benefit of both communities.

\section{Site Architects and Site Architectural Processes}

The site architect will be the responsible official for the execution of architectural processes at each DOE site. The site architect coordinates with the DOE Information Management Council and the DOE Information Architecture Program Manager to ensure alignment of site architectures. The vision for the site architecture process creates a site architects governance 
board to ensure that IT investments are aligned among sites. CIO involvement ensures compliance with Office of Management and Budget (OMB) guidance for capital IT investments.

\section{Stewardship}

The principle of stewardship is the safeguarding of assets for the good of the organization. Departmental information (an important asset) and its stewardship are illustrated in the following information architecture principle and cartoon.

Principle: Information is not only a Departmental asset but also a National asset for which DOE management and staff are the stewards.

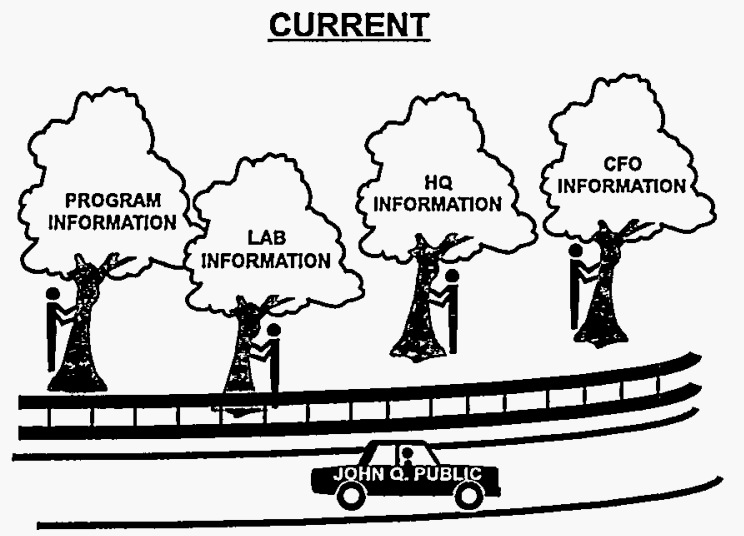

- Possession ownership limits re-use

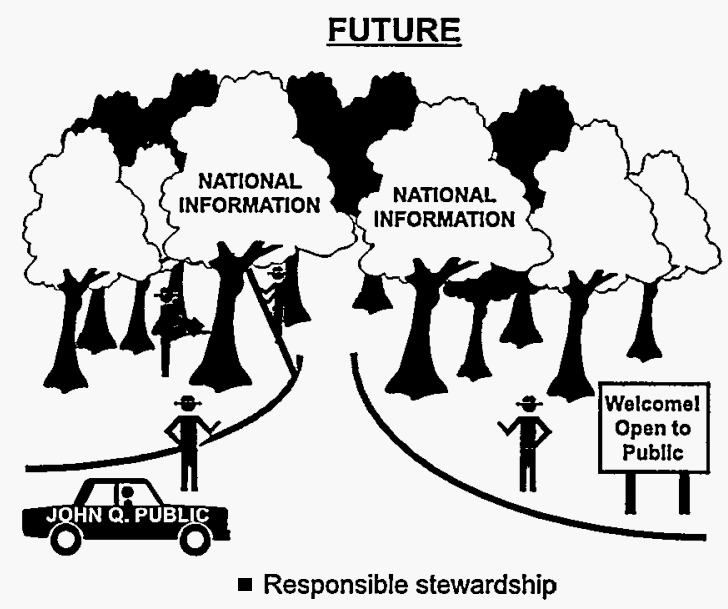

As over-possessive ownership is removed as a barrier to widespread sharing and collaboration, the availability of information will bring the Department into the future based upon responsible stewardship. Ownership of information should not be a barrier to sharing and collaboration. On the contrary, ownership is needed to collect, validate, and update information. Therefore, corporate systems teamwork and promotion of corporate esprit de corps, establishment of clear and easy procedures for information sharing, and clear definition of roles and responsibilities for information owners and information users are necessary for removing the barriers.

\section{ClO Support and Endorsement}

High-level support at the Assistant Secretary level is necessary to empower the CIO to encourage, foster, sponsor, and allocate resources to site architectural efforts. The CIO, in partnership with DOE business leaders, can ensure a fully architected environment. The vision allows the CIO to justify budgeted information management (IM) funding through the architectural process. 


\section{Enterprise Vision Drivers}

A variety of drivers push for fulfillment of the enterprise vision. Many of the drivers were developed at IMPACT IV, and others have been identified through industry research.

Legal mandates (Clinger-Cohen Act and OMB guidance)

Justifiable IT budgets

Timely response to rapidly changing business, Government, economy, and technology at all levels

Continuous transformation and rapid change in the IT environment

Information products and services shared with other Federal, State, and local jurisdictions and private industry

Movement of IT focus from internal integration and towards external integration

Site architectures nurtured by full enterprisewide architectural definition and leveraged by other sites

IT resources deployed effectively, and serving as an enterprisewide change agent

Technology developments (as technologies converge and evolve) that allow mutation of capabilities to meet customer demands

\section{STANDARDS FACT}

The International Standards Organization (ISO) 9000 standards represent an international consensus for a quality system to ensure the effective operation of a business, whether in public or private sector. They are used to ensure quality in a variety of disciplines from manufacturing to information management services. Over 80 countries have adopted the ISO 9000 series as national standards. Thousands of businesses are operating ISO 9000-based quality systems to ensure that products and services meet customer requirements. Several ISO 9000 series standards are part of the DOE Profile of Adopted Standards. 


\section{Business Subarchitecture Vision}

The DOE Information Architecture will provide all business lines and functions with representation in the architectural process. The business subarchitecture identifies the business functions and areas that will be supported by the information, data, applications, and technology subarchitectures. This will enable users and customers to share information widely, transparently, and efficiently even as business needs change.

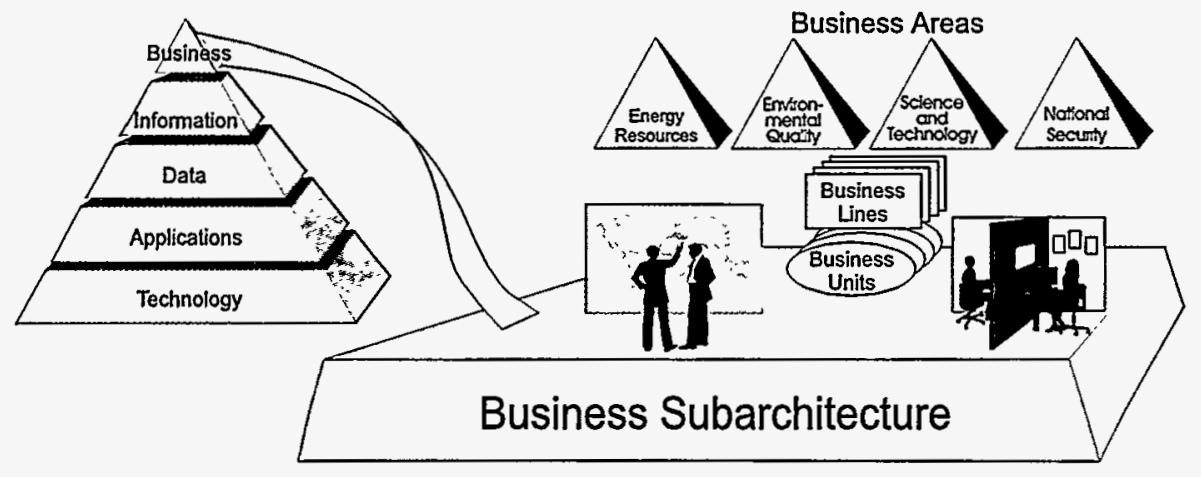

The business subarchitecture is the context within which the business of DOE operates. Its inter-relationships to the other four subarchitectures provide a linkage between business lines and levels of the architecture.

The business of DOE, like any other enterprise, is defined by its policies, strategy, products, services, customers, geographical span, and partners. This definition is respondent to the annual Departmental Performance Agreement with the President. The business subarchitecture will be iterated and modified dependent upon changes in the annual Performance Agreement.

\section{Mission and Business Areas}

As described in the DOE Strategic Plan, the mission (business) is "to foster a secure and reliable energy system that is environmentally and economically sustainable, to be a responsible steward of the Nation's nuclear weapons, to clean up our own facilities, and to support continued United States leadership in science and technology." The plan identifies and defines four core business areas that effectively utilize and integrate the unique Departmental scientific and technological assets, engineering expertise, and facilities to achieve the DOE mission.

Energy Resources - Assure adequate supplies of clean energy, reduce U.S. vulnerability to energy supply disruptions, encourage efficiency and advance alternative and renewable energy technologies, and increase energy choices for all consumers. 
National Security - Support and maintain a safe, secure, and reliable enduring stockpile without nuclear testing; safely dismantle and dispose of excess nuclear weapons; provide technical leadership for national and global nonproliferation and nuclear safety activities; and develop and support nuclear reactor plants for naval propulsion.

$\square$ Environmental Quality - Reduce the environmental, safety, and health risks and threats from DOE facilities and materials; safely and permanently dispose of civilian spent nuclear fuel and defense related radioactive waste; and develop the technologies and institutions required for solving domestic and international environmental problems.

Science and Technology - Use the unique resources of the Department's laboratories and the country's universities to maintain leadership in basic research and to advance scientific knowledge, focus applied research and technology development in support of the Department's other business lines, contribute to the Nation's science and mathematics education, and deliver relevant scientific and technical information.

\section{Corporate Management}

Economic productivity is the desired result achievable through promotion of sustained U.S. economic growth. The DOE enterprise stimulates creation of high-wage jobs and technology transfer to the private sector through diversity in research and development collaborations, energy efficiency and pollution prevention, and global DOE technology usage and exports.

Corporate Management is the business function that underpins each core business area. It supports activities such as management oversight, policy, legal and regulatory compliance, program and project management, customer interface, planning, acquisition, budgeting, real property management, records management, administration, information management, financial management, environmental safety and health, and security. These functions are reinforced through communication and trust and implementation of best business practices. 


\section{DOE Business Context}

DOE fulfills its mission through successful delivery of its products and services to customers and stakeholders. Figure 3-2 illustrates the internal and external factors driving the business of DOE.

Figure 3-2, DOE Business Context

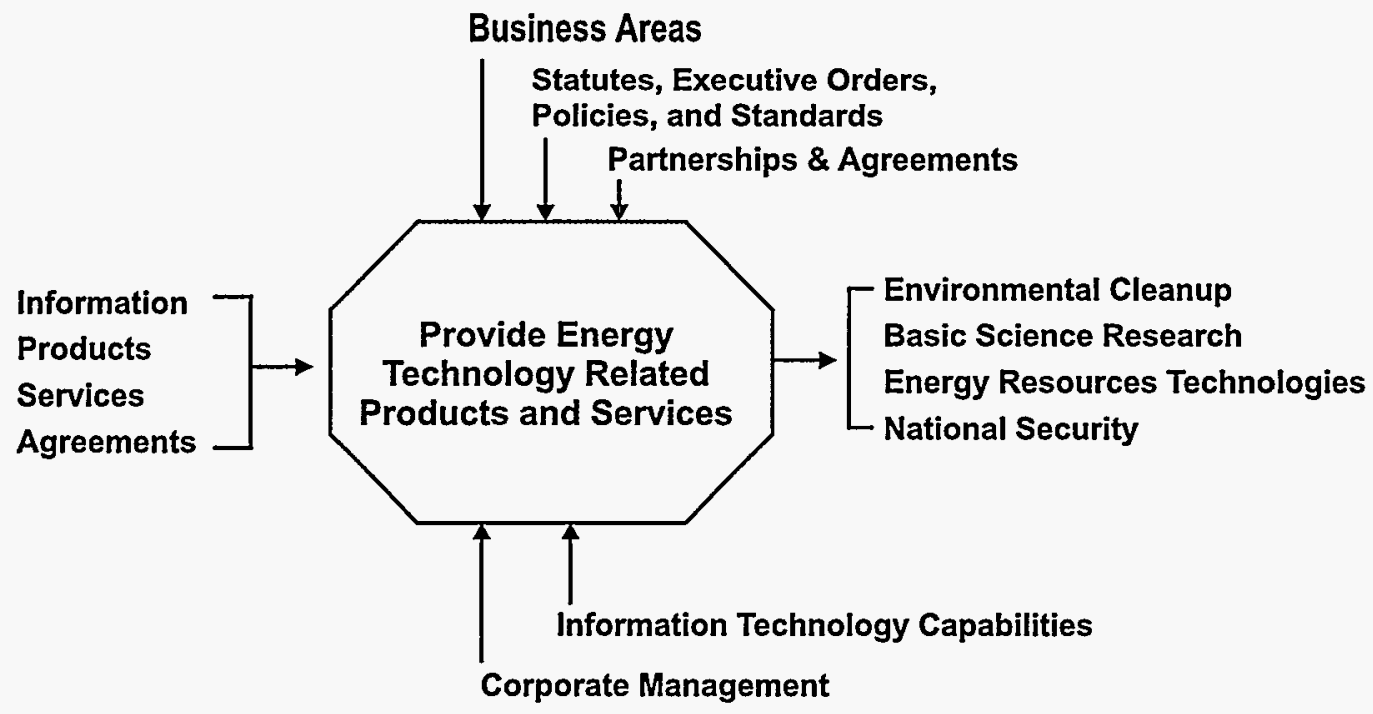

\section{DESTANDARDS FACT}

The Integration Definition for Function Modeling (IDEF) standard, FIPS PUB 183, provides the IDEF modeling language as a means for completely and consistently modeling the functions of a system or enterprise. The language is generic, rigorous and precise, concise, conceptual, and flexible. FIPS PUB 183 is a Government standard that is part of the DOE Profile of Adopted Standards. Figure 3-2, DOE Business Context, was produced using IDEF, and represents the highest level of business functions for DOE.

\section{Composite Business Functions}

The business subarchitecture defines the needs of the organization in each of the four core business areas and corporate management. Common business functions among the core areas are served through the infrastructure, which is provided by corporate management. The business subarchitecture clearly identifies the common, as well as the unique, functions of individual Program Offices or sites. These functions are business needs supported by information technology through the DOE Information Architecture Conceptual Model. The following are common business functions. 
Note: Check marks, as opposed to bullets, indicate that there is elaboration in an appendix of the Vision document.
$\checkmark$ Promote DOE
$\checkmark$ Manage Funds
$\checkmark$ Set Policy Direction
$\checkmark$ Office Management and Administration
$\checkmark$ Programmatic Oversight
$\checkmark$ Manage Human Resources
$\checkmark$ Manage Facilities
$\checkmark$ Infrastructure Oversight
$\checkmark$ Manage IM Resources

Each of these functions incorporates many business activities. "Promote DOE," for example, includes marketing benefits to the public, Congress, and President. Each of those activities can be decomposed into multiple levels of detail. For a detailed listing of the business needs supported by these functions, refer to appendix A, Prototype Business Model.

\section{A User's View}

Symptoms of stovepiped, application-driven information include redundant, untimely, and poorly partitioned business data. Knowledge workers in a seamless user-centric architecture, based on open systems, access user-defined information on demand. An architected environment provides the necessary flexibility, responsiveness, ease of use, and affordability to enable users and customers to share information widely, transparently, and efficiently-even as business needs and technologies change. Throughout the architectural process, representatives of the business community are involved to ensure that business needs are met through the integrated architecture.

Principle: Information products and services are user-centric and customer-driven.
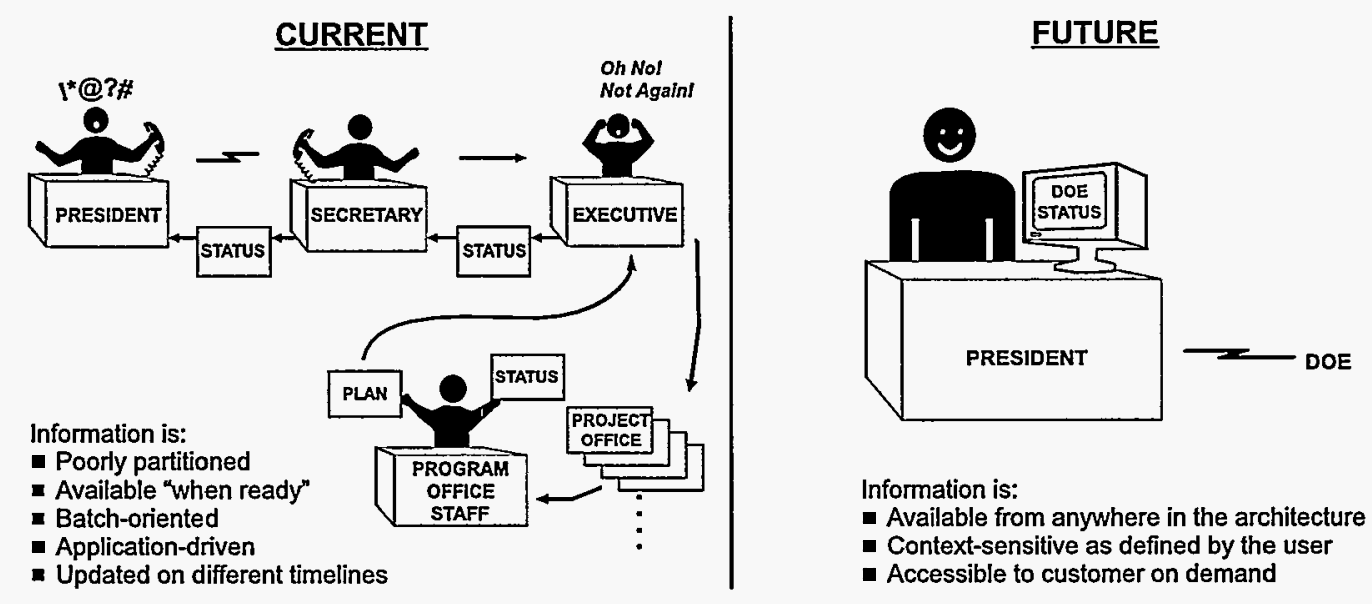


\section{Business Subarchitecture Drivers}

By identifying common, as well as unique, functions of individual Program Offices or sites, the business subarchitecture reveals redundancy caused by different organizational views of the same processes. To reduce the complexity of information systems, the same process is used to identify redundancy in data and technology. Populating data once at its origin and subsequently using the data in a shared mode provides economies of scale by eliminating redundant, untimely, and inaccurate information. Ultimately, this simplification leads to significantly reduced costs. The information architecture drives the creation of standards for shared data and fosters compatibility across the organization.

Organizations needing to do more with less are attempting to reduce costs by optimizing the use and reuse of remaining resources. Many organizations realize that the expertise and experience of their employees are valuable resources. With this in mind, decision making is improved by shifting the responsibility onto teams with shared business concerns. This fundamental workplace change enables organizations to operate in a functional rather than a geographic mode. Costs are cut by reducing unnecessary duplication of expertise in every location and by communicating across geographic boundaries. Collaborative technology is driven by workers dispersed across multiple locations. Even when recognized as a best business practice, collaborative efforts are difficult to introduce into an organization ill-prepared for the move to team-based work styles. 


\section{Information and Data Subarchitecture Vision}

Information (and its context) is a valuable corporate asset. DOE will create and sustain information and data subarchitectures that provide for management of redundancy, validity, and currency of data. High-level information and system models will enable information objects to interoperate with evolving applications and the technology infrastructures to promote information sharing. This process will separate or decouple data from applications logic and business process rules.

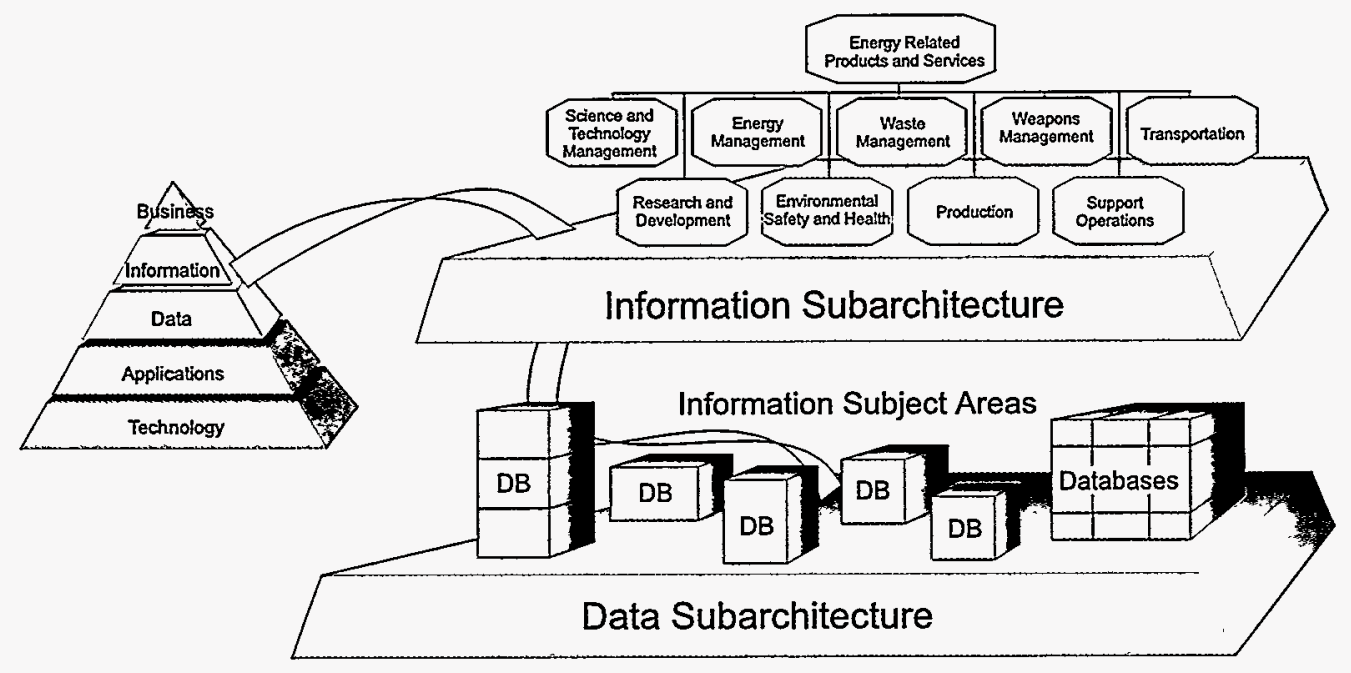

The results of the IMPACT IV meeting identified the need to combine the information and data layers of the DOE Information Architecture Conceptual Model, because of the close relationship between information and data. A key element is the accessibility and use of data to produce information to service business needs. Another element is the need to define and populate data once in the organization, with subsequent reuse based upon data sharing. Data sharing is based upon common definitions maintained in an enterprisewide data dictionary. This initiative requires data stewardship throughout the organization.

\section{An Information Model}

In these days of information overload, an unambiguous approach to the definition of data entities used by the business unit is important. Figure 3-3, Fundamental and Composite Business Object Definitions, presents an information model. The business unit entities (e.g., equipment, customers, procedures, etc.) form the building blocks of the model. These entities are then categorized by the type of information they contribute to the model. The composites in the center of the diagram are scenarios that draw information from the categorized entities. The analytical representation of various aspects of the scenarios comprises meaningful information for the business unit. 
Figure 3-3, Fundamental and Composite Business Object Definitions

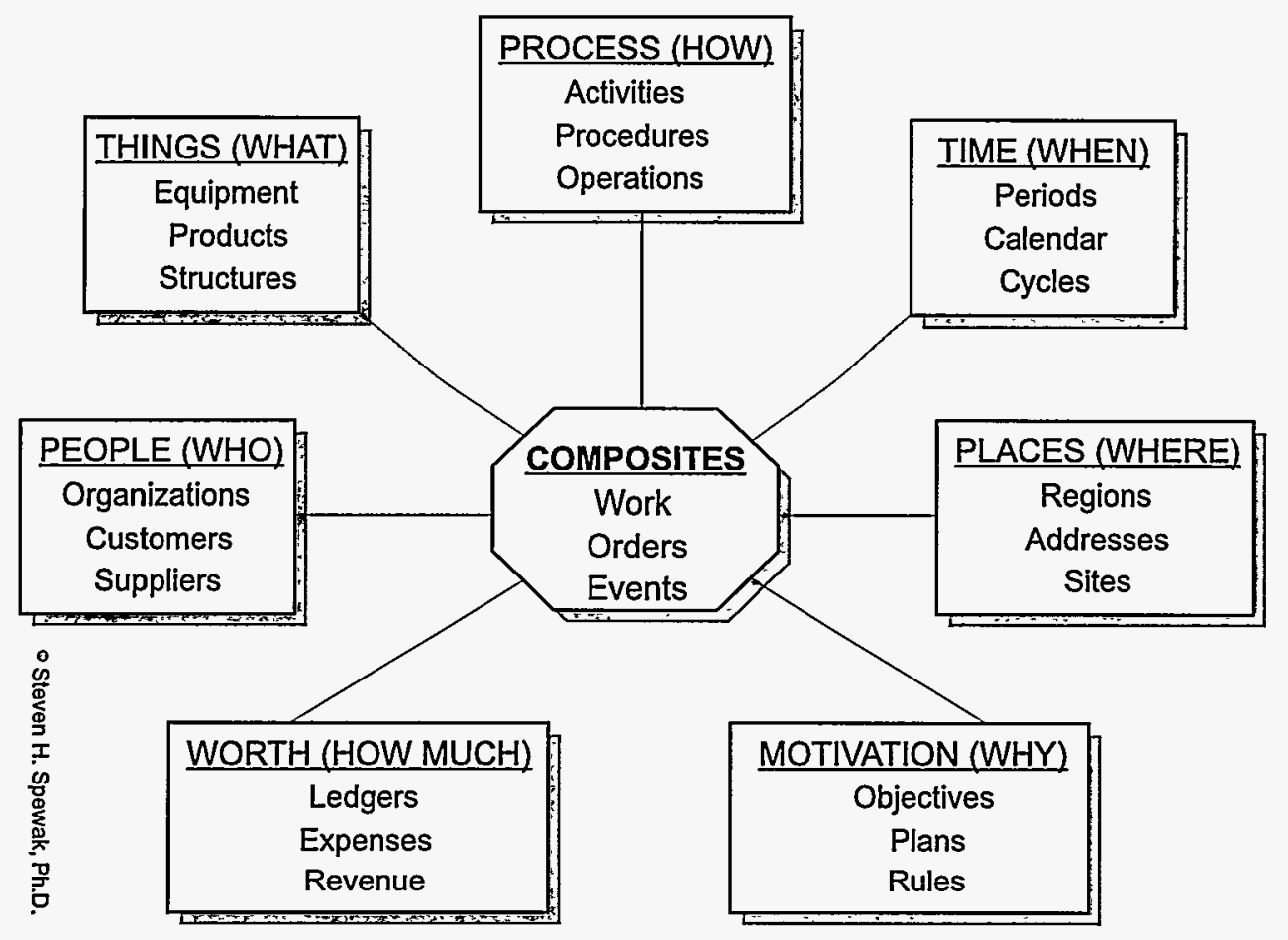




\section{Four-Tier Approach to Data Flow}

The information model is a horizontal cross-section of the information layer of the business unit. The four-tier approach to data flow takes a vertical cross-section of a specific query for information. Within the data subarchitecture, critical data management, access, and security considerations are taken into account. The four tiers are Presentation/Acceptance, Applications, Data, and Metadata. The following table illustrates the components of this approach using a Freedom of Information Act (FOIA) request as an example.

\begin{tabular}{|c|c|c|}
\hline \multicolumn{3}{|c|}{ Table 3-1, Four-Tier Approach to Data Flow } \\
\hline Tier & \multicolumn{2}{|c|}{ Tier Components } \\
\hline Presentation/Acceptance & - FOIA Request & - Query Response \\
\hline Applications & $\begin{array}{l}\text { - Document Management } \\
\text { - WEB Browser } \\
\text { - Electronic Mail } \\
\text { - Workflow }\end{array}$ & $\begin{array}{l}\text { - Scanning } \\
\text { - Routing } \\
\text { - Redaction } \\
\text { - Authoring }\end{array}$ \\
\hline Data & $\begin{array}{l}\text { - Rules } \\
\text { - Repository } \\
\text { - Approvals } \\
\text { - Sites } \\
\text { - Contractors }\end{array}$ & $\begin{array}{l}\text { - Organizations } \\
\text { - Author } \\
\text { - Addressee } \\
\text { - Document Name } \\
\text { - Topic }\end{array}$ \\
\hline Metadata & $\begin{array}{l}\text { - Userid } \\
\text { - Date/Time Stamp } \\
\text { - Profile } \\
\text { - IP Address }\end{array}$ & $\begin{array}{l}\text { - Router } \\
\text { - Messaging } \\
\text { - Document ID }\end{array}$ \\
\hline
\end{tabular}

At the Presentation/Acceptance Tier, information is generally requested in one of the following three ways.

Request originated by a user

$\square$ Request originated by another user

Request originated by an executive portfolio of information that is automatically updated (seamlessly)

\section{䟚 STANDARDS FACT}

Presentation/Acceptance Tier - The Internet Engineering Steering Group has approved as a proposed standard the Internet-Draft, A Common Schema for the Internet White Pages Service. This document specifies the minimum set of attributes of a White Pages entry and describes how new objects with those attributes can be defined and registered. 


\begin{tabular}{|l|}
\hline Structured Query Language (SQL) is a \\
popular relational data base language \\
standardized in 1986 by American \\
National Standards Institute (ANSI). \\
Since then, it has been formally \\
adopted as an international standard \\
by the ISO/International \\
Electrotechnical Commission \\
(ISO/IEC). It has also been adopted \\
as a Federal Information Processing \\
Standard Publication (FIPS PUB) for \\
the Federal Government. FIPS PUB \\
127-2 is part of the DOE Profile of \\
Adopted Standards.
\end{tabular}

Query results are presented to the user for acceptance by a spreadsheet graph. Examples of technologies serving the Presentation/Acceptance Tier are Object Linking and Embedding (OLE), SQL, spreadsheets, and other personal productivity tools.

At the Applications Tier, data is created, read, updated, and deleted based on business need. Data management is provided through the application, possibly through the intervention of a system administrator to define access rights. The application and systems administrator manage the data and define access rights to the applications, based on rules of data stewardship.

The Data Tier includes independent islands of data, which form information when intersected with related data and an inference is drawn.

The Metadata Tier provides the necessary data to address, stamp, mark, and route data and information around the enterprise through applications via communications devices, servers, and workstations. 


\section{A User's View}

The information subarchitecture defines the user's view of enterprise information. Data produced in the day-to-day operations of the organization intersect to create information. An open, interoperable information environment is the vision for the data and information subarchitectures. The vision separates information and data services from applications logic and business process rules.

Principle: Information architecture is based on an open systems approach.
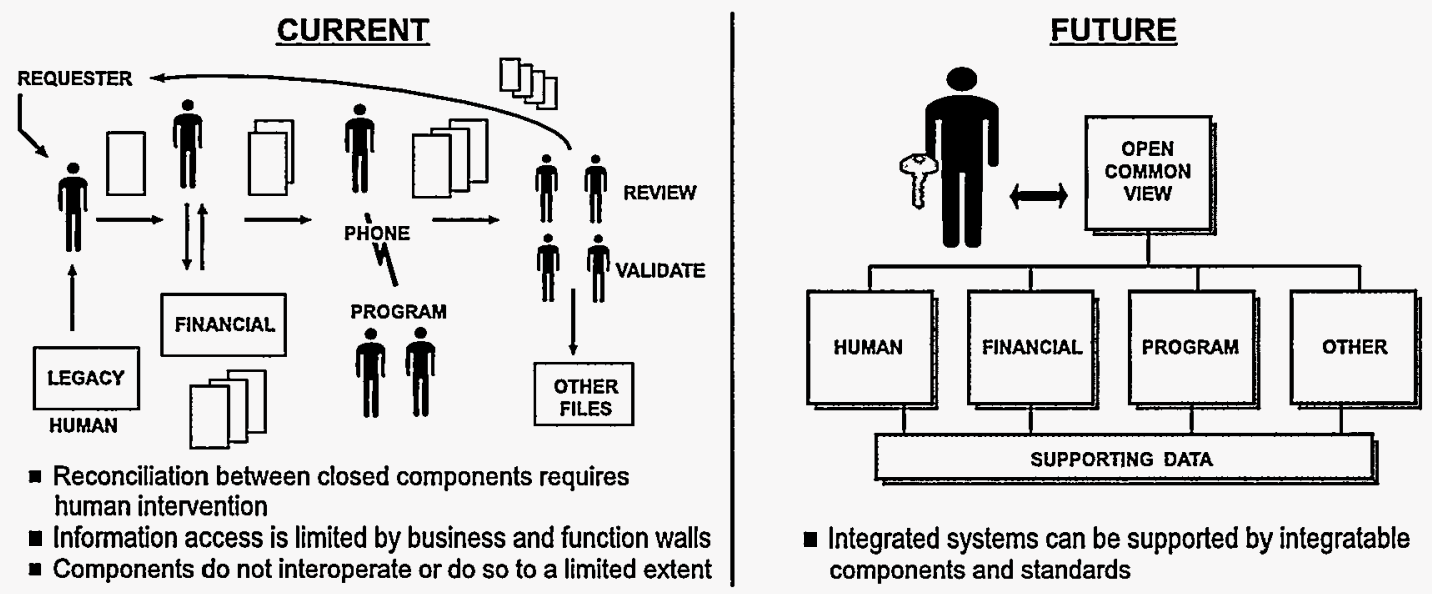

- Integrated systems can be supported by integratable components and standards

\section{Information and Data Subarchitecture Drivers}

Several factors drive the fulfillment of the information and data subarchitectures.

Users have high expectations.

How, when, and where information is created, used, and displayed is changing faster than traditional systems can be built.

Proliferation of new information presentation, query, and data mining techniques causes rapid changes in the dynamics of information access and use.

The level of customer focus on information processing has increased.

The architected environment provides for a greater level of crosscut sharing.

Rapidly expanding system storage capacities and the availability of remote servers and workstations provide a variety of application tools and access means. 


\section{Applications Subarchitecture Vision}

Applications provide an informational window into the Department's data resources. An open framework of data interchange and interoperability across the enterprise will ensure access to secure, non redundant data.

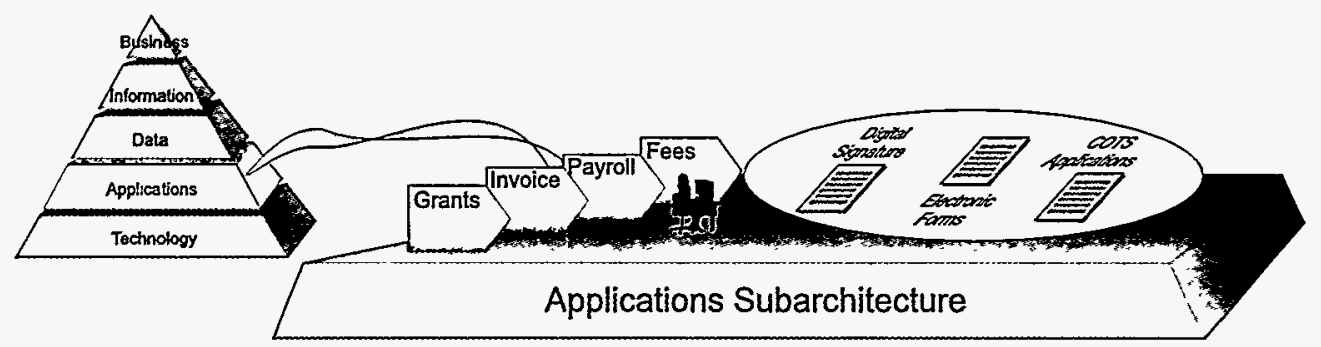

Applications are the tools to manage organizational data. Applications capture, store, manipulate, transfer, and report information to the business community and serve internal and external customers. The applications architecture transcends past and present needs to help define the functions required to meet DOE business goals. Future needs are considered through the architectural process, which includes appropriate standards to ensure timeliness and compatibility.

\section{A User's View}

A personalized desktop is the user's vision of applications architecture. Knowledge workers in a user-centric and architected environment are delivered a user interface adaptable to when and where they need to work. The toolset of applications provides personal productivity tools. COTS products integrate seamlessly with corporate and programmatic applications to present a personalized workspace.

Principle: The information architecture is based on modular components and an open systems approach.

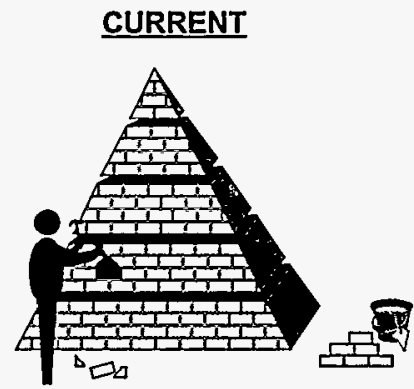

- Non-modular - all work is major reconstruction

- Difficult to adapt to changing requirements

- Difficult to scale up or down to meet changing demands

- Difficult to insert modemized capabilities

\section{FUTURE}

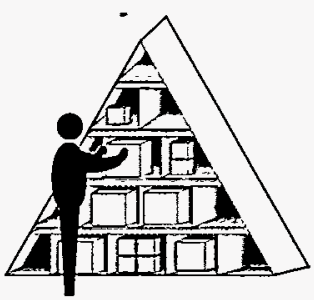

- Expedite upgrades/replacements

- Minimize effect on other modules during maintenance

- Make changes to small segments

- Scale capabilities to most changing needs

- Reduce investment risks and development costs 
Personal productivity applications are available on demand. Authoring tools, statistical analysis tools, collaborative work tools, graphics and presentation tools all work together without the barriers of licensing, irreconcilable versions, or incompatible file formats. Intelligent software agents create a portfolio of frequently accessed applications and present functions to the user at login. Basic word processing and inbox tools appear on the desktop each time the workspace is activated.

\section{APPLICATIONS FACT}

Making millions of records available on the Web was successfully completed by a Los Alamos National Laboratory (LANL) research librarian. Significant resources were required to sort the data into common elements to allow meaningful search results.

Government Computer News, January 12, 1998

Employees perform business functions using applications as tools. They author a document or review and approve the work of others, analyze data to develop trends, and conduct research through queries. Employees also use intuitive query tools popularized by browsers.

The worker is no longer dependent on a single workstation because applications and data are available through multiple channels, according to the worker's profile. A single userid and password opens the door to a personalized profile that defines access rights to applications and data needed to do the work. With a geographically dispersed workforce, users can move about freely and still access electronic messages, documents, or research materials. The materials are gathered electronically from a variety of sites and electronic media.

\section{Applications Deliver Business Information}

Applications deliver reliable, up-to-date, and secure information that is usable in flexible and intuitive ways. Confidence in the accuracy of information is a critical success factor in the vision. Effective and efficient management controls provide assurance through an architected environment. The information and data layers link to the business layer by seamless delivery of business information via the applications layer.

The DOE Document Online Coordination
System (DOCS) integrates word
processing, document management,
imaging, and workflow modules. A senior
official reviewing a draft can work online or
on paper, have his comments captured
electronically, authorize approval (or return
for further work), and route the work in
progress to others for concurrence.

Volume IV, Vision
Department of Energy Information Architecture 
Applications share data already created and maintained in a repository or data warehouse. Applications use basic data (e.g., employee name or organizational code), retrieved from the repository. Each piece of data is created once, reducing the costs of maintaining multiple applications that store similar data. Data stewardship provides the guidance to guarantee authority, dependability, and integrity of the data. Enterprise applications spanning multiple data warehouses provide information to answer broad business questions.

Principle: DOEwide access to information is the rule rather than the exception.
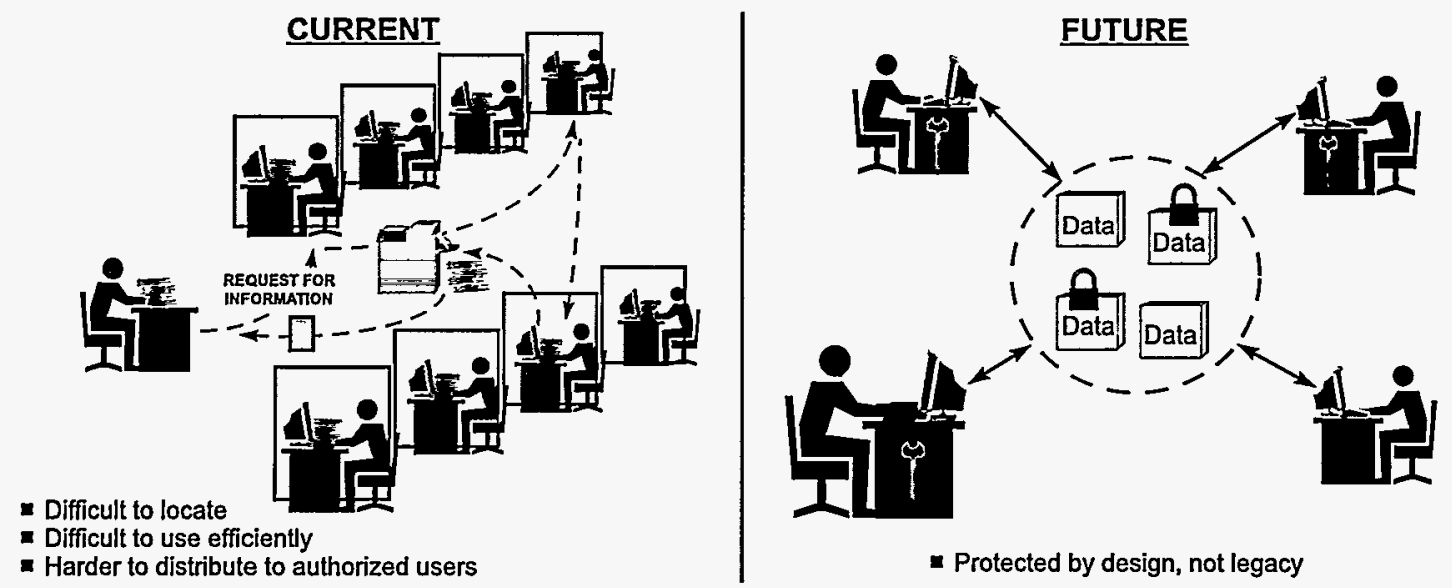

A data dictionary is the master index to a data warehouse. Every data entity is defined and described in detail. Standard descriptions ensure that each data element is unique and can be shared across applications and the enterprise. For example, common acronyms for each Management and Operations ( $\mathrm{M} \& \mathrm{O})$ contractor maintained in the data dictionary and stored in the data warehouse are not replicated in multiple application databases YTANDARDS FACT
Year 2000 compatibility, which has captured the
attention of the world, demonstrates the
architectural standard by default, not by design.
The high costs of data storage in the early years
of the information revolution prompted
programmers to adopt the practice of storing a
year with 2 bytes. The National Institute of
Standards and Technology (NIST) FIPS PUB 4-1,
Date Standard, now specifies 4 bytes. across the enterprise.

The vision makes data open and accessible by supporting an open architecture. Standardsbased interfaces provide the guidelines to allow a single data source to be accessed in multiple ways by multiple applications. The window to Departmentwide data resources provides seamless and integrated data correlation. 


\section{Application Design Characteristics}

Applications in an architected environment share many characteristics. The following list of design characteristics is detailed in Information Architecture, Volume III, Guidance. These attributes serve as an effective checklist for the vision.

Maintainability - Ease of repairing architecture components

Adaptability - Ease of changing information forms or functional characteristics

Portability - Ability to move applications transparently among locations

Data Autonomy - Ability to access data separated from applications and assembled on demand

Interoperability - Ability to work cooperatively among multiple heterogeneous networks, processors, and databases

Appliance Connectivity - Connectivity of a variety of information appliances with versatile set of graphical user interfaces (GUIs)

Transparency - User perception that everything works as a whole, rather than as a collection of components

Security - Preplanned, appropriate, integrated protection for data, information, and technology capabilities

\section{DOE Corporate Systems}

A vision for corporate systems at $\mathrm{DOE}$ includes a focus on the shared data warehouse services supported by architectural standards. Supporting the deployment of corporate applications are data storage, data management, a data dictionary, communications, and a corporate network. Figure 3-4, Corporate Systems Share Services, shows how DOEwide corporate systems, including legacy systems, share services with supporting standards.
IR APPLICATIONS FACT

DOEInfo, an employee data repository, stores current and historical DOE employee information for multiple uses. The Oracle tables, stored on the mainframe, are updated nightly from current personnel systems. Access is available through tools (e.g., SQL queries and Crystal Reports) and applications, such as the Corporate Human Information Resource System (CHRIS). 
Figure 3-4, Corporate Systems Share Services

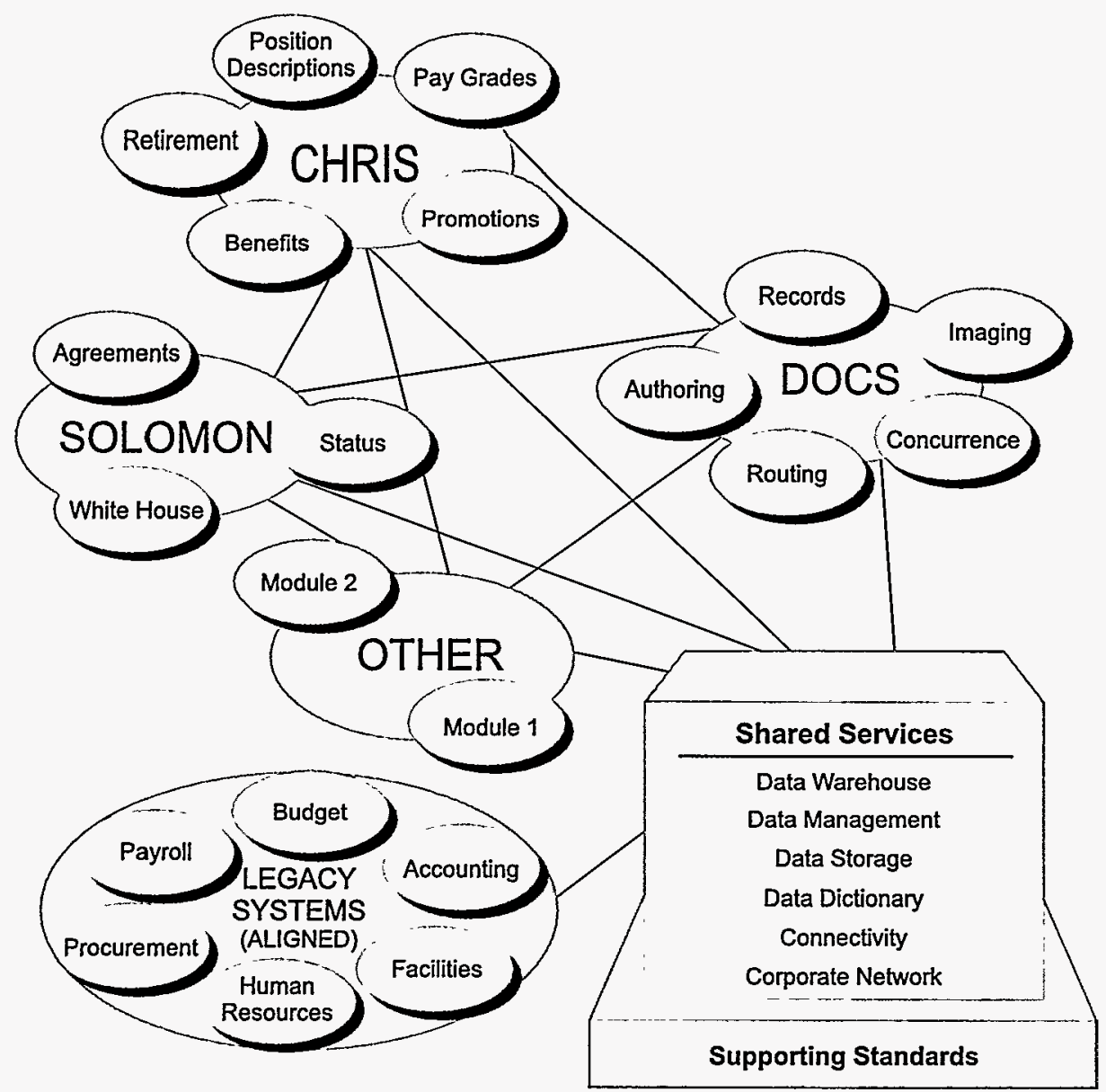

The vision includes maximum use of COTS products that can be easily integrated into the architectures. Modules can be added, exchanged, or removed without affecting related applications or shared services. A new imaging application can be exchanged for the current module in a document management system. Legacy systems can be aligned with the architectures by meeting requirements established by shared services and standards.

The first module of CHRIS automates the Standard Form (SF)-52, Request for Personnel Action. CHRIS illustrates enterprise support, provided through multiple sites, to streamline human resource functions across locations. 
An inventory of systems is an important product of the applications architecture. The following list is a sample of corporate system categories available or planned for DOE.
$\checkmark$ Document Management
$\checkmark$ Financial Management
$\checkmark$ Human Resources
$\checkmark$ Performance Management
$\checkmark$ Environmental Safety and Health
$\checkmark$ Procurement and Grants Award
$\checkmark$ Facilities Management

For a detailed matrix of sample corporate applications, refer to appendix B, Corporate Applications Inventory. Solomon (refer to appendix B) is an example of a system that supports a critical component of the "Promote DOE" business function as part of the business model. It provides status on performance measures on the agreements between the President and the Secretary.

Appendix B also provides examples of application capabilities, references to DOE guidance, as well as some key technologies supporting the applications. Appendix D, DOE Corporate Guidance, provides a list of referenced guidance.

\section{Applications Subarchitecture Drivers}

Applications reflect the cultural changes of an organization. As DOE evolves to meet growing expectations during downsizing, applications are changing. Application development or systems acquisition reflects business strategy to meet critical information needs. Workgroup applications support external and internal collaborative efforts.

Applications will be smaller and focus on limited functions. Related modules work together not only due to shared application architecture standards, such as data elements identified in the data dictionary, but also presentation standards. A common look and feel reduces the learning curve. Applications adjust to the platform with little or no modification. Procuring application templates reduces the costs and time involved in many software development efforts.

Additional drivers that influence the applications architecture include user perceptions and increasing expectations for productivity tools and business information. Interoperability and transparency, along with the demand for knowledge to solve business problems, continue to challenge applications architects. 


\section{Technology Subarchitecture Vision}

The technology subarchitecture enables and responds to changing applications, information requirements, and data exchange of an enterprise's business processes. The technology infrastructure will ensure data access, protection, and security. Application distribution services will provide the capabilities and mechanisms to supply hardware and software configurations, and architected processing platform preferences. The supporting information technology standards will mitigate vendor dependencies as part of the technology architecture. The IT infrastructure will provide the underpinnings for storage, access, and reuse of components on an enterprise scale.

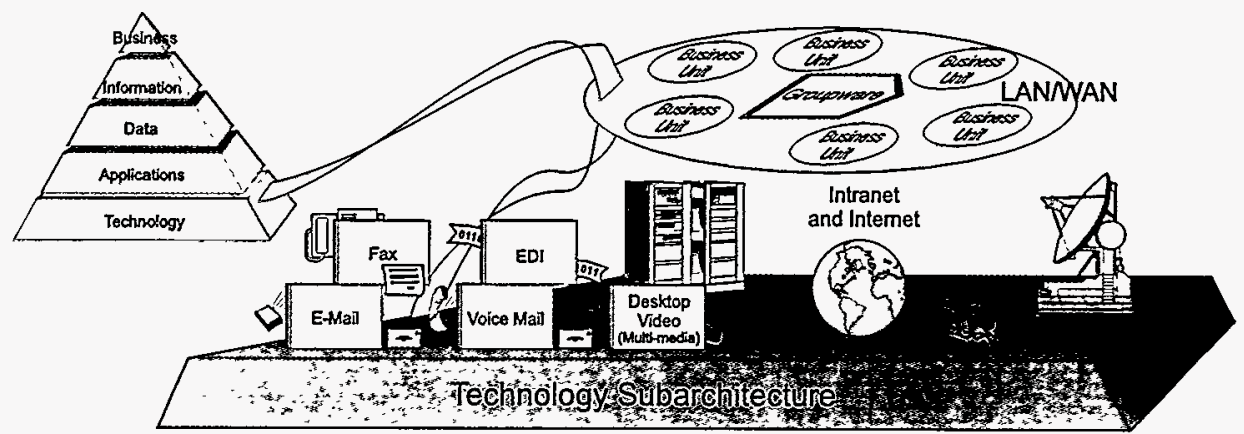

Underlying the other layers of the architecture is the technology subarchitecture, which sustains the critical services and protocols to empower the vision. Technology enables (or disables) the ability of the enterprise to execute business processes.

\section{A User's View}

Technology provides the interface to people, applications, and business information. The cartoon from IMPACT V describes user experiences working with technology.

Principle: The information architecture incorporates a robust interface that optimizes the nature, efficiency, and effectiveness of the human operator.
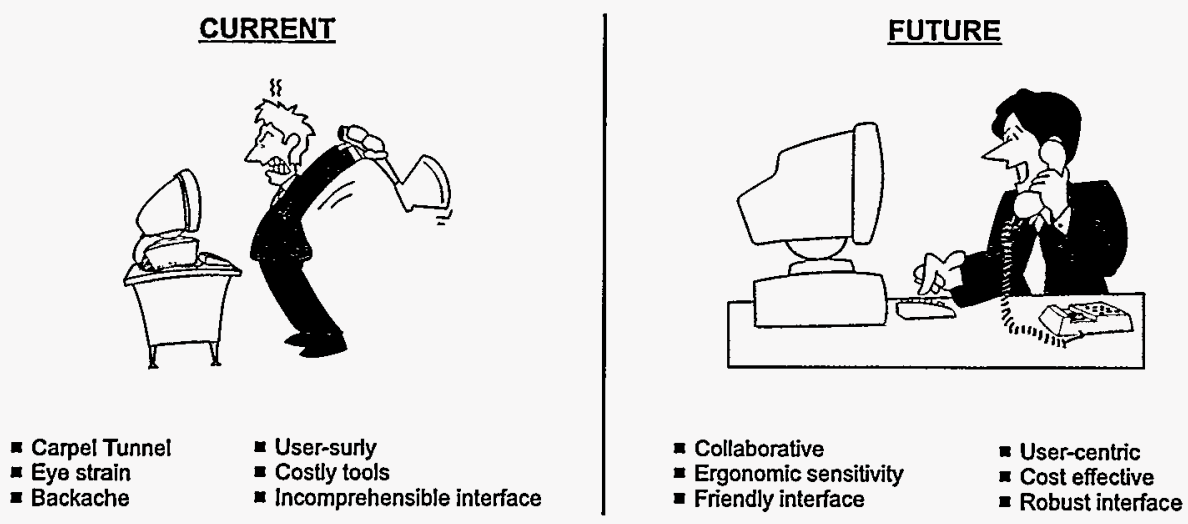
Productive employees work efficiently in an environment adjustable to their nature and style of working. Adaptable furniture, supportive and adjustable chairs, flexible lighting, shared team workspace, easy-to-see display screens, interactive white boards-many technical components contribute to the work area designed for knowledge workers. Familiar and intuitive interfaces add to the ease in adapting to new applications and technologies.

\section{DEP TECHNOLOGY FACT}

The DOE Adaptive Technologies program offers services to improve the ergonomic sensitivity of the physical workspace environment. Simple adaptations, such as the height of a monitor or a better designed keyboard, can reduce stress.

Users enjoy the productivity derived from working in team rooms equipped with a large, interactive video screens and other capabilities to support electronic team sessions. The ability to see, hear, and share real-time information simultaneously with local and remote colleagues reduces the burden of physical distance and limits to collaboration. The leadership and skills to collaborate in teams are components of the readiness of the user community to optimize the technology.

\section{Technology Links to All Layers}

The technology layer links to the applications layer through shared services provided by the applications. Network services and connectivity deliver distributed applications to the desktop and provide interoperability in heterogeneous environments. Applications are served when and where the authorized user logs in and the server authenticates the user and verifies that the workstation is capable of running the requested application.

The technology layer links to the data layer through the tools that help create, maintain, share, and manage data and make it available to applications. Security services, based on a DOEwide security model, leverage best practices and existing models to assure secure distribution and integration of information.

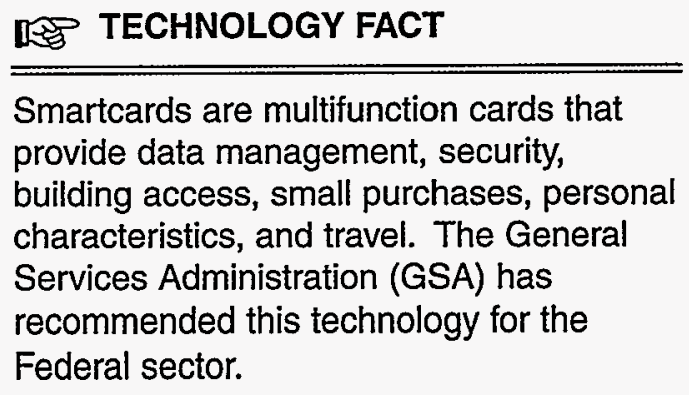

Smartcards are multifunction cards that provide data management, security, building access, small purchases, personal characteristics, and travel. The General Services Administration (GSA) has recommended this technology for the Federal sector. 
The technology layer empowers the delivery of meaningful information across multiple servers. Crosscutting data is delivered on demand to answer a simple or complex query for information. Improved semantic functionality uses the context to differentiate among multiple meanings of a word or to discern similarities between concepts. Intelligent software agents can gather summary information from multiple sites using pull technologies or have it delivered automatically through push technologies.

\section{IECHNOLOGY FACT}

The Office of Nuclear and Non-Proliferation Support (NN) has proposed using an expert system combining artificial intelligence, imaging, and work flow technology to aid in declassification of $\mathbf{2 8 0}$ million pages of information, dating from World War II to the present.

Federal Computer Week

\section{Security and Technology Subarchitecture}

The foundation principles of security are Confidentiality, Integrity, and Availability. These principles should be made part of the elements of all information handled by DOE. Security crosscuts the applications and technology layers of the architecture. Protecting sensitive and secure data is a challenge in a world that encourages global access to information. Many technologies have built-in security components. The principle illustrated in the cartoon focuses on designing built-in security appropriate to the levels of access.

Principle: Security is designed into all architectural elements, balancing accessibility and ease of use with protection of data.

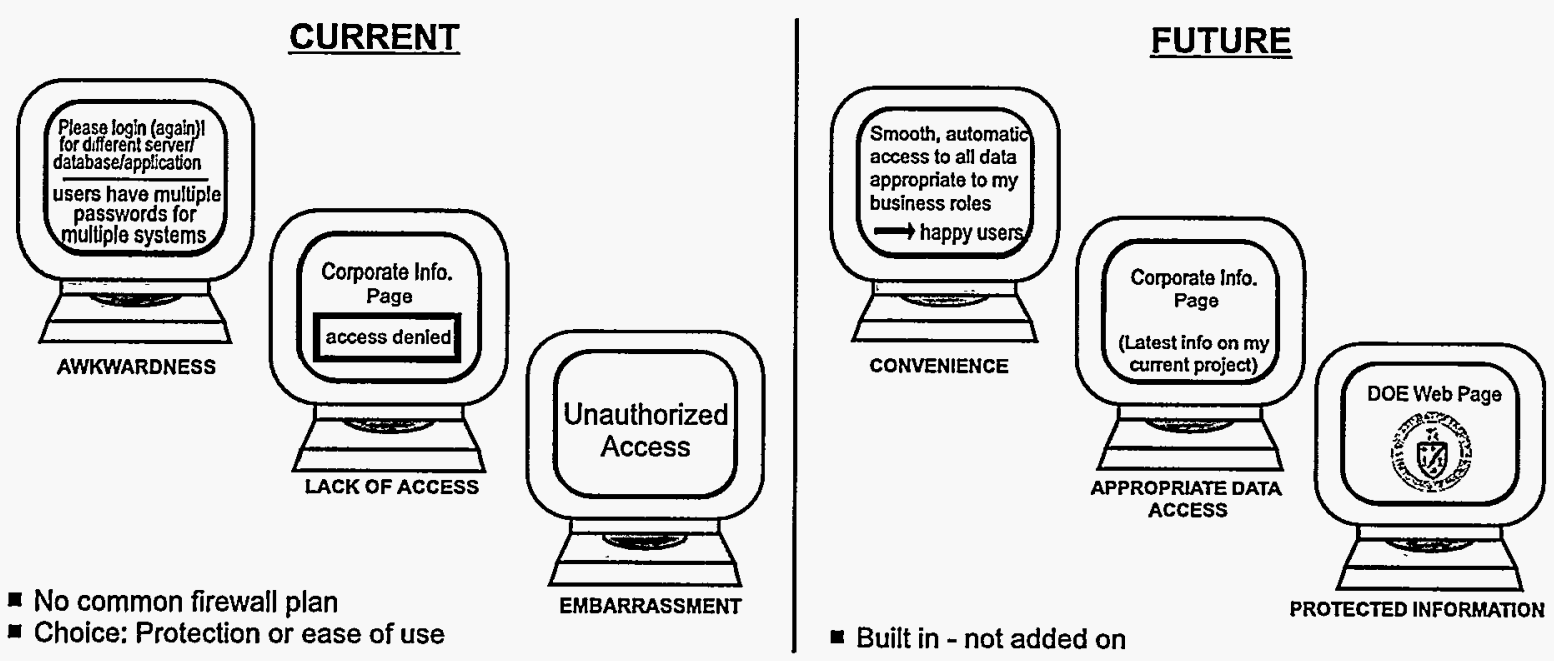




\section{Security and Technology Subarchitecture Drivers}

Several factors drive the fulfillment of the security and technology subarchitectures.

At the desktop, the key to a user's unique profile is the userid and password.

On network servers, the user authentication verifies the user is valid and authorized to access applications and data.

On database servers, update, read, and write accesses ensure that the create, read, update, and delete rules are followed.

Within applications, digital signature replaces paper routing with electronic authenticated signature.

\begin{tabular}{l}
\hline TECHNOLOGY FACT \\
\hline The Data Encryption Standard (DES) used \\
in digital signatures was developed by \\
NIST in 1977 . A more secure method for \\
using the DES algorithm in three \\
operations, called Triple DES, has been \\
developed by the private sector and is a \\
draft ANSI standard. NIST has begun to \\
develop an Advanced Encryption Standard \\
(AES) that could replace the DES and that \\
could be used by Government and \\
industry.
\end{tabular}

\section{Technology Suite}

As various sites execute architecture processes, different technologies will be incorporated in the architectures, dependent upon business, information, data, and application needs. The technologies underpin the site's architected vision, but do not drive the architecture. The technologies are subservient to fulfilling the architected business needs.

A robust suite of technologies is presented in appendix C, Prototype Technology List. The table in appendix $\mathrm{C}$ reflects the ongoing contributions of the DOE Information Management Council through the Corporate Guidance Group (CGG) and the Headquarters Collaboration Group (HCG). Focal areas presented in the Information Architecture, Volume II, Baseline Analysis, are also referenced. Additional research through the Gartner Group and the Futurist Society added to the predictions and assessment of relative maturity and appropriateness of fit to the DOE environment.

Each technology category was analyzed using the model for technology position statements outlined in chapter 4, Architecture In Action. The categories are presented in order as scored by the Vision Architecture Team. Normally, this activity would be carried out by a team of business and information management representatives at all organizational levels (i.e., corporate, program, and site) with appropriate buy-in from their organizations. 
Appendix C, Prototype Technology List, cites examples of approved CGG items, focal areas, and HCG priority projects for each technology. DOE technology projections, spanning several years, are based on current planning and industry forecasts. Multiple technologies are typically involved, adding complexity to the planning cycle to ensure a robust infrastructure. The Applications Architecture (refer to appendix B) illustrates some of those technologies for each application. Internet access, network management, and LAN/WAN access are critical components of many systems (e.g., Solomon).

The prototype technologies in appendix $\mathrm{C}$ were compiled from multiple sources and are not meant to be comprehensive. Many technologies are well-developed tools, being implemented at DOE, while others are still relatively immature. The following technologies are included in appendix $\mathrm{C}$.

$\checkmark$ Information Architecture Process
$\checkmark$ Desktop Platform
$\checkmark$ Whiteboarding
$\checkmark$ Network Management
$\checkmark$ LAN/WAN/Telecommunications
$\checkmark$ Push Technology
$\checkmark$ Data Dictionary
$\checkmark$ Workgroup
$\checkmark$ Network Computing
$\checkmark$ Security
$\checkmark$ Smartcard

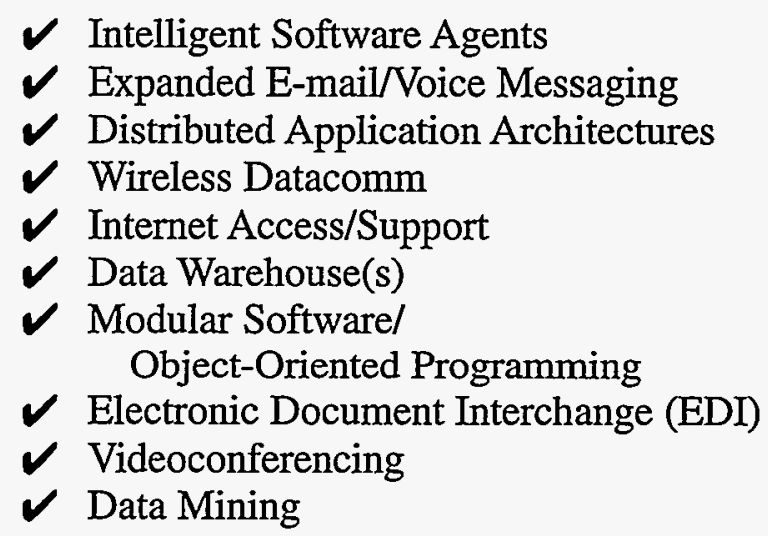

Figure 3-5, Prototype DOE Technology Planning Scenario, presents a fit to the 7-year planning window and suggests some potential impacts to the organization during implementation of the technologies. Implementation plans integrate technologies with applications to develop a schedule that reflects business priorities and appropriate sequencing to ensure success. 


\section{Figure 3-5, Prototype DOE Technology Planning Scenario}

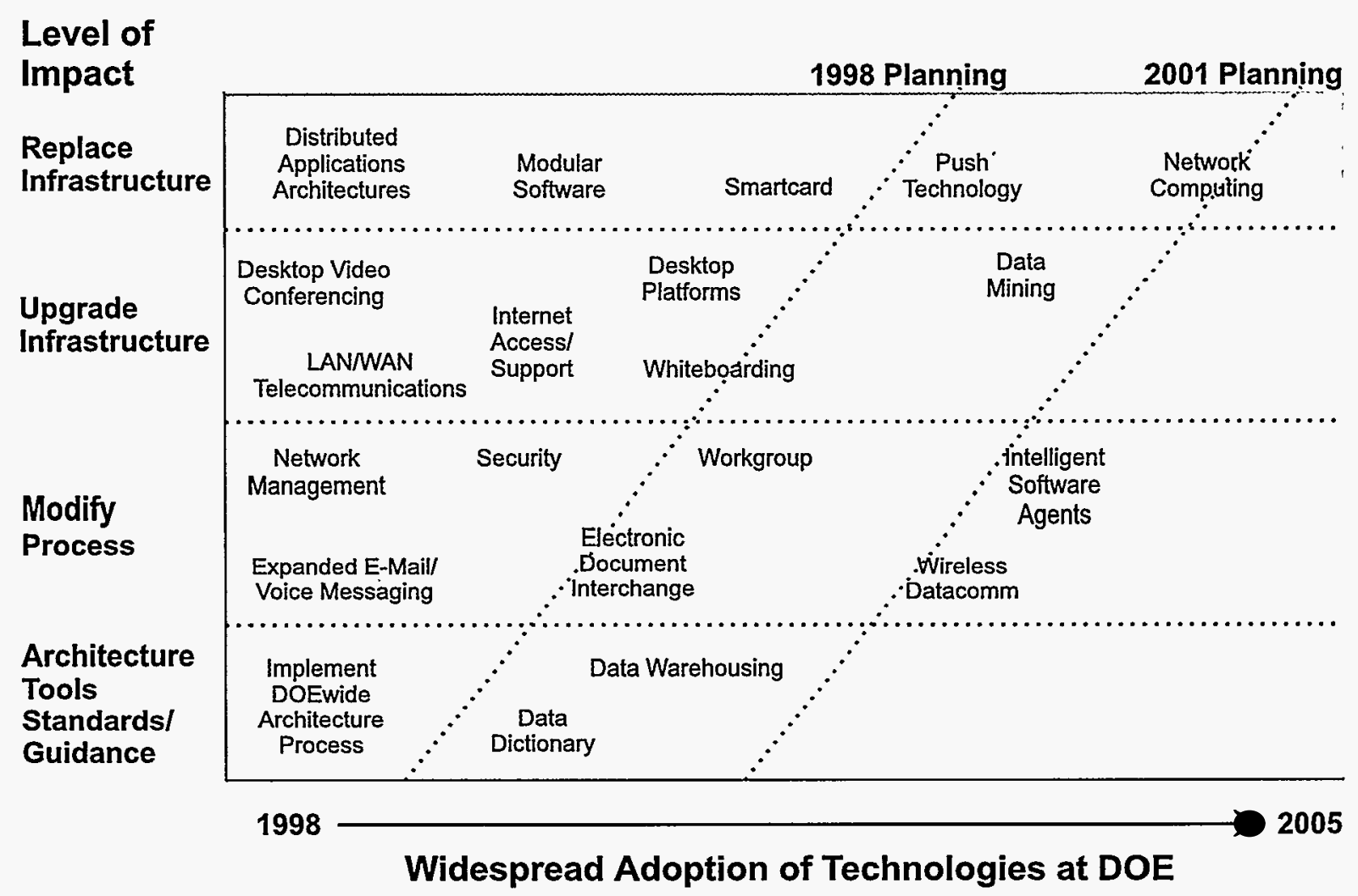

\section{Technology Equals Infrastructure}

The cartoon from IMPACT V summarizes the role of the technology subarchitecture as the infrastructure to link multiple sites and organizations. The vision for a user to have a single point of entry into the complex through seamless integration of applications and technologies is valid. A new DOE employee in the future will interact with a computing device to enter basic human resources information once, in the secure system. The manager, human resources department, and security representative will have access to appropriate information. 
Principle: DOE will provide an information technology infrastructure that links offices, programs, facilities, and field locations together seamlessly.
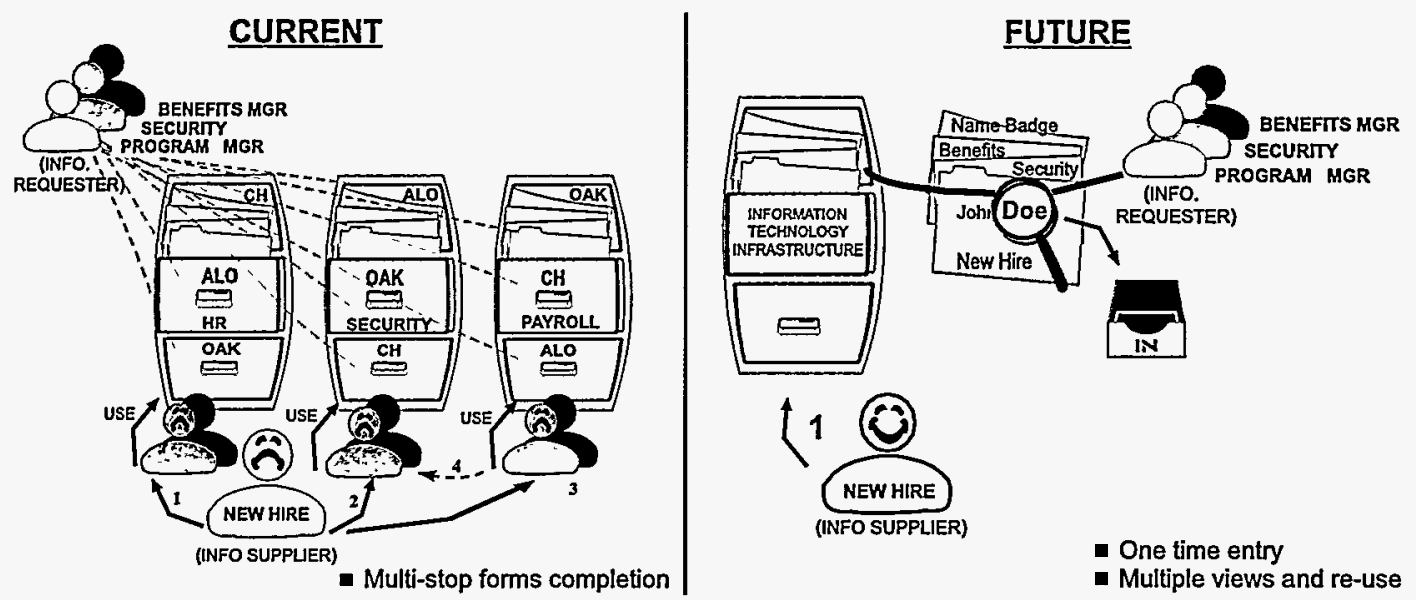

Much of the infrastructure is invisible to the user. Server types, roles, and locations are essential components to process applications and manage databases but are not usually visible to the worker. Protocols, bandwidth, and routers are some critical components linking geographically dispersed users.

Client devices, whether powerful computers, simple terminals, or hand-held devices, are tools of the technology subarchitecture. Procuring, managing, and supporting these assets are processes related to technology architecture. The technology subarchitecture provides the rules and guidance to manage these mechanisms to deliver services in support of the business.

\section{Technology Subarchitecture Drivers}

Many drivers add to the challenges as DOE meets the vision for the future.

Users expect more from technology.

Interoperability is a complex goal in a heterogeneous world.

Rapidly evolving platforms challenge the traditional planning process, especially in bringing legacy systems into alignment with architectures.

Sharing data is a paradigm shift within enterprises, and management support is critical.

The technology subarchitecture provides the strategies to ensure that the appropriate technologies are in place at the right time. Selecting and scheduling technology deployment and application development projects are integral to the planning and implementation cycle. 


\section{Standards Vision}

The standards vision of an open, consensus-based process to implement and withdraw IT standards facilitates the sharing of information by enhancing DOE's ability to interoperate preferably using commercially available computer, communication, and networking equipment and software.

The strategy to achieve this vision is to adopt, implement, and retire consensus-based standards with active participation of DOE users. A key component of this strategy is to include users and subject-matter experts during evaluation of evolving standards.

A high-level description of the standards process is contained in the DOE Information Architecture, Volume I, The Foundations, and further delineated in the Information Architecture Standards Adoption and Retirement Process Service Action Plan. The initial set of adopted standards appears in the U.S. Department of Energy Information Architecture Profile of Adopted Standards. In addition to the Profile document, the base of adopted standards appears in the standards repository on the DOE IT Standards Home Page (refer to appendix G, References). Although the Profile document will be issued annually, the repository will be updated continually to reflect current adopted standards. The repository will also contain proposed standards as they go through the standards adoption process. The repository will be the official profile of record.

Standards may be proposed by an individual, through a site or program point of contact, or by an affinity group that has formed to focus on a particular business or technology area. The proposal can concern the retirement of a standard, the adoption of a standard from a recognized standard body, or the adoption of a proposed standard when an interim standard is needed for effective DOEwide operations.

Industry Infrastructure Standards Develop as Technologies Develop

After the Civil War, through the turn of the century, the railroad industry adopted many standards allowing for rail freight and travel to become more economical. Some of these standards were:

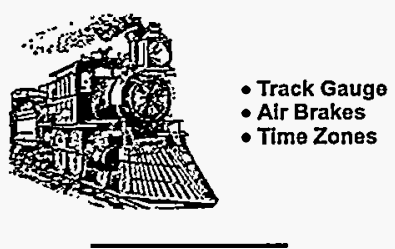

The auto industry began adopting standards early in the 20 th century that specify most everything from the production of basic materials through the end product.

Standards also determine the:

- Accuracy of gas pumps

- Composition of gas and oil

- Roadway construction

- Specifications of road signs
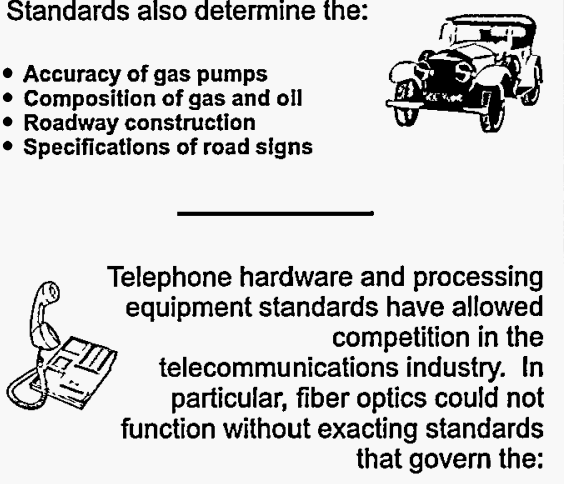

- Fiber diameter

- Fiber to fiber alignments

- Accurate measure of light pulses

The last quarter of the 20 th century has seen the meteoric rise of the computer industry. The continuing adoption of hardware and software standards will assure system

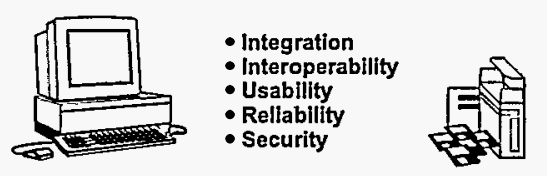


As sites and programs develop their own standards profiles, they should use the DOE IT Standards Repository as a source. If a DOE Element wants to include a standard not appearing in the repository, the responsible standards point of contact should propose DOEwide adoption of the standard through the Standards Adoption and Retirement Process. If the standard is not adopted, the DOE site or program should ascertain whether the standard is important to its mission accomplishment. If the standard is adopted, it will refine and enhance the DOE IT Standards Repository. Likewise, if a site or program does not want to include a standard from the DOE IT Standard Repository, the point of contact can propose that the standard be retired. Retiring standards not applicable to DOE Elements will allow the DOE IT Standards Repository to remain current and useful.

DOE encourages participation in voluntary standards development bodies in support of the National Technology Transfer and Advancement Act of 1995 (Public Law 104-113) and OMB Circular A-119, Federal Participation in the Development and Use of Voluntary Standards (OMB A-119). IT personnel should report involvement in these organizations to the DOE IT Standards Manager (Carol Blackston, HR-43, 301-903-4294) to be recognized as standards experts and serve in an advisory capacity during consideration of standards in their area of expertise.

\section{Technology and Standards Service Areas}

The 10 service areas of the DOE IT Standards Program were first identified at IMPACT I in October 1994. The team originated the Standards Reference Model (figure 3-6), which specified eight layers of service areas (i.e., user services, application services, programming services, data management, data interchange, network services, operating systems, and hardware platform). Two crosscutting service areas, security and management services, were also identified.

DISTANDARDS FACT
The Digital Signature Standard selected by
NIST, in cooperation with the National
Security Agency to be the digital authenti-
cation standard of the U.S. Government is
contained in FIPS PUB 186. This standard
evolved to be used in designing and
implementing public-key-based signature
systems. FIPS PUB 186 is part of the DOE
Profile of Adopted Standards.


Figure 3-6, Standards Reference Model

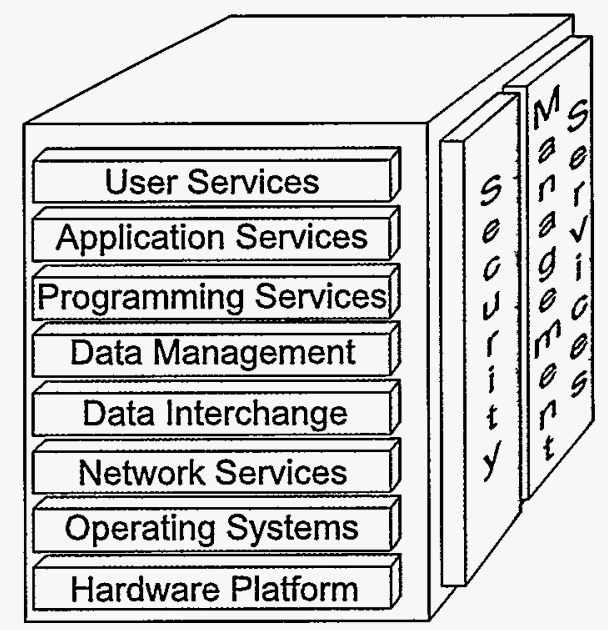

Technologies are deployed in an organization based upon adopted standards. The technology areas have been grouped within the 10 standards service areas outlined in the DOE IT Standards Program and presented in table 3-2, Standards Service/Technology Areas.

\begin{tabular}{||l|l||}
\hline \multicolumn{2}{|c||}{ Table 3-2, Standards Service/Technology Areas } \\
\hline Standards Service Area & Technology Area \\
\hline \hline User Services & Desktop Platform \\
\hline \multirow{4}{*}{ Application Services } & Intelligent Software Agents \\
\cline { 2 - 3 } & Push Technology \\
\cline { 2 - 2 } & Workgroup Computing \\
\cline { 2 - 2 } & Data Mining \\
\cline { 2 - 2 } & Whiteboarding \\
\hline Programming Services & Modular Software/Object Oriented Development \\
\hline \multirow{3}{*}{ Data Management } & Data Dictionary \\
\cline { 2 - 2 } & Data Warehouse \\
\hline
\end{tabular}




\begin{tabular}{||l|l||}
\hline \multicolumn{2}{|c||}{ Table 3-2, Standards Service/Technology Areas } \\
\hline Standards Service Area & Technology Area \\
\hline \hline \multirow{3}{*}{ Data Interchange } & Expanded E-mail, Voice Messaging \\
\cline { 2 - 3 } Network Services & Electronic Document Interchange \\
\cline { 2 - 3 } & Video Conferencing \\
\hline \multirow{2}{*}{ Operating Systems } & Network Management \\
\cline { 2 - 3 } & Internet Access/Support \\
\cline { 2 - 2 } Hardware Platform & LAN/WAN/Telecommunications \\
\hline \multirow{2}{*}{ Security } & Network Computing \\
\hline \multirow{2}{*}{ Management Services } & Platform to Support Technology Infrastructure \\
\cline { 2 - 2 } & Security/Access Methods \\
\cline { 2 - 2 } & Smartcard \\
\cline { 2 - 2 } & Distributed Application Architectures \\
\hline
\end{tabular}

The technologies selected at each site and their relevance to Standards Service Areas should be outlined at the conclusion of a site architecture as part of its Profile of Adopted Standards. The 10 Standards Services Areas provide the framework for deployment of technologies to achieve the architectural vision.

\section{Expansion of the DOE Information Architecture Program}

Over the past 3 years, the Departmental Information Architecture Program has been in the defining stage of the architecture. The Information Architecture, Volume IV, Vision, completes the definition phase of the program. The next phase is expansion, in which specific architectural projects will be conducted. Activities will be conducted at two levels-the Information Architecture Program Level and the site and Program Office level.

At the Information Architecture Program level, the following activities are anticipated.

$\square$ Sponsorship of pilot enterprise architecture projects

$\square$ Development/deployment of architectural toolsets

$\square$ Development of assessment processes (including appropriate measures)

$\square$ Development of alignment processes

$\square$ Delivery of appropriate education/training programs 
At the site and Program Office level, the following activities are anticipated.

Execution of pilot enterprise architecture projects or other repeatable architectural processes

Use of architectural tools

Participation in architectural assessments

- Participation in education/training programs

As part of the education and training process, and as part of the transition from the definition phase to the expansion phase, a detailed description of the Enterprise Architecture Planning (EAP) process is included in chapter 4, Architecture In Action. Accompanying the process description is relevant data gathered from the EAP process executed in the Office of Energy Research (ER) during 1997. 


\section{Architecture In Action}

An ongoing process for architectural definition will enable the Department of Energy (DOE) to receive international acclaim for leadership and accomplishments in managing information as an essential asset. Information technology to support a secure and reliable energy system, environmental cleanup, scientific research, and national security will be provided through the DOE Information Architecture Program. Performance results derived from an efficient planning model will eliminate duplicate work, allow sound technology decisions, and deliver the right information when and where it is needed.

This chapter illustrates the achievable possibilities of an architected vision forged through a disciplined process. Architecture In Action is depicted in this chapter by fictional sidebars, a step-by-step process description, and fact boxes detailing results of the Enterprise Architecture Planning (EAP) process conducted in the Office of Energy Research (ER). In the fictional sidebars, Shirley Greyhorse, the heroine, serves as a member of the Core Team where she represents the business goals of her Program organization, Energy Production. She and her supervisor, Dan Kendall, bring valuable lessons learned through the successful completion of the architecting process in their organization.

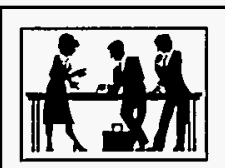

\section{Architecture In Action}

On June 19, 2006, Shirley Greyhorse begins her day at the U.S. Department of Energy. As a Program manager in the Office of Energy Production, she works with activities related to achieving objectives in the Energy Production portion of the DOE Strategic Plan. Over the past 10 years, she has worked with technical experts in achieving the Department's strategic goals, including the information technology specialists who helped her manage critical information in cost-effective and useful ways. They created a technology environment that makes the best possible use of available information and personnel resources.

As Shirley approaches her office, her personal-computer assistant turns on the lights and greets her, "Good morning, Shirley! Would you like your messages?" She replies, "Oh, sure, let's get started." "Voice, video, or shall I read?" asks the assistant. "Please read the voice mail and e-mail items. While we're working on the mail items, do a media search for items related to the electric industry competitiveness initiative," said Shirley.

After completing the text readout, the personal assistant announces, "You have several video clips, news wire stories, and Congressional reports concerning the competitiveness legislation, shall I display them?" Shirley replies, "Yes, start with the video clips from the news service."

The onscreen frame video window displays Dan Kendall's smiling face. Mr. Kendall, Director of the Office of Energy Production, is in Vienna, Austria, with the Secretary of Energy to receive a Merit Award for the Department's work towards an agreement on an international electrical grid. Shirley smiles. This award represents a lot of hard work on the part of many Departmental and contractor employees. Regardless of their technical speciality, these colleagues demonstrated that communication, trust, and collaboration are essential to every successful project. 


\section{Enterprise Architecture Planning}

EAP, as developed by Steven H. Spewak, Ph.D., demonstrates that a Federal Agency can

successfully develop and continue an architected process to support a business mission with costeffective and appropriate technical solutions. The mandates for an architected plan come from multiple sources, as identified in chapter 1 , Architectural Vision Drivers, and by other DOE business leaders. In addition, downsizing efforts, standards to promote interoperability, and the ever-growing chorus of voices from program managers and executives demand a strategic approach for information management planning.

\section{Building the Project}

The Secretary of Energy champions the project that brings teams of people from across the enterprise to work collaboratively. A high-ranking official of a large Program, in partnership with the Chief Information Officer (CIO), manages the process with contractor support. Architecture teams in each Program include business and technical staff. A corporate Core Team also includes business and information management staff from all units, and trained consultants serving as process guides.

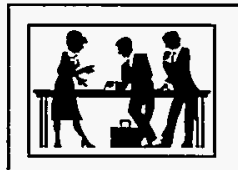

\section{Architecture In Action}

Shirley leans back, sipping her coffee, watching the awards ceremony, and thinking, "A few years ago, we would not have been able to collect the information, develop the modeling capability, and perform the analyses necessary to guide the legislation and agreement to this point. It would have taken months of effort in an area we knew nothing about, and, in the end, we probably would have developed a system that included only a fraction of what the business partners needed. The DOE information architecture project certainly proved useful to this business venture."

"Understanding the business requirements and putting together the right team to build a capable information system based on common data structures made it all happen, just the way Ray Saunders said it would-eventually. I remember when he convinced me to help with the architecture ..."

Additional reference groups provide consultation from Program management, Program architecture teams, and technical perspectives of the DOEwide enterprise. The architecture initiative involves the close cooperation of many organizations and multiple disciplines. As a result, the Core Team's recommendations are credible and acceptable. Figure 4-1, Participants in the DOE Architectural Process, illustrates the typical teams involved in a DOE architecture effort.

Volume IV, Vision 3/98 

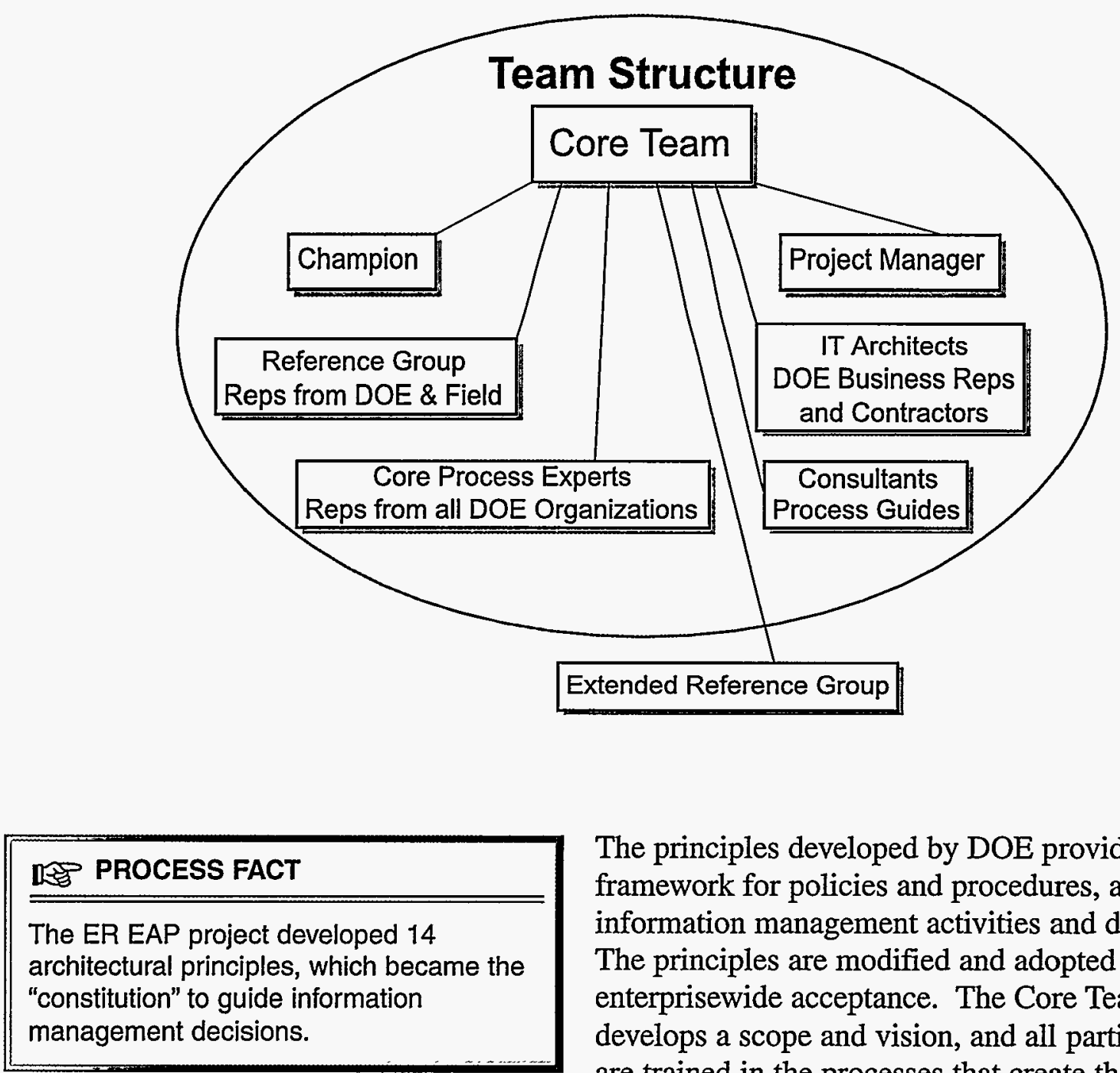

The principles developed by $\mathrm{DOE}$ provide the framework for policies and procedures, as well as information management activities and decisions. The principles are modified and adopted to reflect enterprisewide acceptance. The Core Team develops a scope and vision, and all participants are trained in the processes that create the tools for architecting.

The team works collaboratively to create a business model that reflects the business activities supporting the work of DOE and defines common activities to explain the way DOE conducts business. 
"Ray, we need some strong technical experts to help you with the architecture project," stated Raoul Lopez, the Chief Information Officer.

"Raoul, I think Shirley Greyhorse should be part of the team. I worked with Shirley a couple years ago to build an architecture at her site; she's now a Headquarters Program manager. Her architecture experience and technical expertise should give us plenty of insight. Besides, her organization is a key player, and they implemented an organizationwide architecture last year. Sharing lessons learned would be very useful in relating the information architecture implementation to solving real DOE business requirements," said Ray.

Later, Shirley agreed to participate in the project. "You know, Ray, we still have an architecture problem in our Office. The Ridgeway Power Marketing Administration still hasn't come on board. They hold a critical piece of corporate information in a database that the rest of the organization can't access. Now that we've completed our major architecture effort, I imagine it will cost time and money to bring them onboard. Unfortunately, the common architecture is the only way to achieve our mission. Maybe working with your group will help us get RPMA architected too."

The team defines the information and data used in each activity. They analyze the data and strategize how information systems can address data needs on a DOEwide basis and deliver data where it is needed. Toolsets are employed to illustrate which activities use which data entities and what applications support the data.

The team catalogs all current and planned applications and technologies. New applications and technology projects are estimated based on what data needs to be created and where. The team sequences the applications and plans technology projects needed to support the applications. A development and migration plan reflects the sequencing based on corporate business and data needs.

\section{Role of Architectures}

Architects depend on well-defined standards to ensure that each component of a building contributes to the success of the entire building. The DOE process to develop a business architecture results in a master list of key business activities. The data and information architectures populate the corporate data dictionary with all data entities identified and described using a common business vocabulary. Data warehouses provide storage for data used by multiple applications. Architected applications reflect the modular approach to building applications in an order that is both business- and data-driven. The technology architecture ensures that technology projects provide the infrastructure necessary to run the applications. 
The architected environment allows for both near-term and long-term resource planning. Architectures are continuously updated and changed to reflect all related forces. As business goals evolve, data needs change, affecting the plan for applications and technologies. This process supports the role of business and data driving technology, not the other way around.

\section{Business and Information Architectures}

The first steps in architecting focus on clearly understanding the business processes and information needed to conduct business. The Business Process Team examines the DOE business functions and business models prepared by program office representatives. Consolidating common activities, the team prepares a comprehensive list of business functions defined by activities. Activities are described on the basis of "what" is done, but independently of who, where, why, when, and how attributes.

Table 4-1 defines a business function with six different business activities. Each could further be defined to specify more detailed activities.

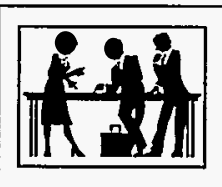

\section{Architecture In Action}

At the first Team meeting, Ray explained what needed to be done during the architecture process. "Although this is an information architecture, we will be looking at both information and processes, including manual and automated processes," he said. "It may surprise you that many daily processes are common to the other organizations in the architecture. You'll identify processes, software, and information involved in organizational activities and compare them to others. In this way, we'll work collaboratively to create a business model of the functions that support the organization's business."

Using a facilitated group process, the Architecture Team identified 63 activities or processes required to fulfill missions. These processes comprised planning, management, control, and operational support functions. As Ray expected, the overlap of common processes was quite large -47 processes were common among the organizational groups.

\begin{tabular}{||l|l||}
\hline \multicolumn{2}{|c|}{ Table 4-1, Business Function/Activity Matrix } \\
\hline Business Function & Business Activity \\
\hline \hline \multirow{4}{*}{ Programmatic Oversight } & Manage Proposed and Funded Work \\
\cline { 2 - 3 } & Request and Obtain Proposals \\
\cline { 2 - 3 } & Select New and Ongoing Work \\
\cline { 2 - 2 } & Allocate Non-Financial Resources \\
\cline { 2 - 3 } & Perform Work Evaluations \\
\cline { 2 - 2 } & Manage Work Evaluation Process \\
\hline
\end{tabular}


Common activities shared across different components of DOE create opportunities for cost savings through corporate system applications and greater efficiencies. Understanding the work processes and information flows also promotes the use of a common business vocabulary, which supports information system development and process improvement.

Other business functions support strategic goals for the different business lines and describe the work of specific Program Offices. Business functions that support the strategic goal for cleaner and cheaper electricity include activities related to electricity generation, types of power plants, cost of electricity, consumption, and effects of competition and environment measures.

\section{Value of Business Model}

Identified activities relate to the data entities identified in the data architecture and existing and planned applications. Activities are mapped to DOE programs to show which activities are performed by whom. This process highlights DOEwide applications necessary to support common activities. Activities are also compared to existing systems to show which activities are automated. The business model supports all other architectures and is revised and updated as part of a continuous cycle.

\section{Data Architecture}

The data architecture describes the entire set of corporate, shared-data entities that support the business of DOE. Recent approval of these entities at the highest levels of DOE provides guidance to maintain an enterprisewide data dictionary documenting common data entities used in multiple systems.

The data architecture simplifies complexity by establishing an unambiguous language. The data entities describe the person, thing, place, or event about which DOE needs to keep data. Analysis of business activities provides the data entities; the team defines each entity and its characteristics. Following are some samples.

Model - Formula or rules to answer information needs, such as the formula to compute cost per kilowatt hour

Organization - Entity related to DOE with attributes such as name, address, region, purpose, and suborganizational units 
Metrics - Measurements or criteria to provide data about performance evaluation, supply, consumption, or other statistics

Entities have relationships with one another and to business activities. Understanding these relationships helps determine how data is used. Table 4-2 shows the relationship between business functions and data entities. Each activity is analyzed to determine whether it creates the data or uses (references) the data entity.

In table 4-2, business activities related to production of electricity create $(\mathrm{C})$ data about electricity generated, as well as associated costs. The Sales activities reference (R) or use data stored in the Cost entity and formulas in the Model entity to compute the Income generated for the power plant.

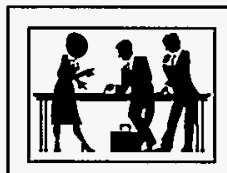

\section{Architecture In Action}

During the next steps, the Team defined information and data used in each activity. At the same time, the Team members identified manual and automated processes and inventoried software, applications programs, and hardware. It soon became clear that the overall organization had multiple information needs and diverse information systems and had never before performed a comprehensive assessment of corporate information requirements. The subsidiary organizations had different needs within similar systems as well as local, overlapping systems to meet individual requirements.

In the Energy Production architecture process, Shirley's organization was able to eliminate duplication and consolidate data in more "user-centric" systems. For example, several standalone automated systems were being used to track costs per kilowatt hour of power produced at various facilities. Since the systems operated independently, consolidated cost comparisons were compiled manually. As a result of the common architecture, the data once maintained in independent systems are now available (aside from the RPMA piece, which is resisting the architecture) for analysis electronically on a real-time basis.

Table 4-2, Business Activities to Data Entities Matrix

\begin{tabular}{|l|c|c|c|c|c|c|}
\cline { 2 - 8 } \multicolumn{1}{c|}{} & \multicolumn{6}{c|}{ Data Entities } \\
\hline $\begin{array}{l}\text { Business } \\
\text { Activities }\end{array}$ & Electricity & $\begin{array}{c}\text { Model/ } \\
\text { Formula }\end{array}$ & $\begin{array}{c}\text { Cost/ } \\
\text { Income }\end{array}$ & Organization & Metrics & When \\
\hline Production & $\mathrm{C}$ & $\mathrm{C}$ & $\mathrm{C}$ & $\mathrm{C}$ & $\mathrm{C}$ & $\mathrm{C}$ \\
\hline Sales & & $\mathrm{R}$ & $\mathrm{R}$ & $\mathrm{R}$ & $\mathrm{R}$ & $\mathrm{R}$ \\
\hline Consumption & $\mathrm{R}$ & $\mathrm{R}$ & & $\mathrm{R}$ & $\mathrm{R}$ & $\mathrm{R}$ \\
\hline Safety & & $\mathrm{R}$ & & $\mathrm{R}$ & $\mathrm{R}$ & $\mathrm{R}$ \\
\hline Trending & $\mathrm{R}$ & $\mathrm{R}$ & $\mathrm{R}$ & $\mathrm{R}$ & $\mathrm{R}$ & $\mathrm{R}$ \\
\hline
\end{tabular}




\section{Value of Data Architectures}

Sharing data, not duplicating it, improves the integrity of data, reduces embarrassment from the use of incorrect data, and cuts costs and duplication of effort. The data model and common terminology provide a standardized approach for all DOE development efforts. Figure 4-2, Data Architecture Observation, presents a model for the benefits of data sharing.

\section{烸 PROCESS FACT}

The ER Data Architecture is a model of all data needed to support business functions. It includes a listing of data entities (types of data), definitions, and the relationships between the entities. Fortytwo data entities and their interrelationships were documented.

Figure 4-2, Data Architecture Observation

\section{With Data Sharing, all who need access to corporate data have access to timely, accurate data}

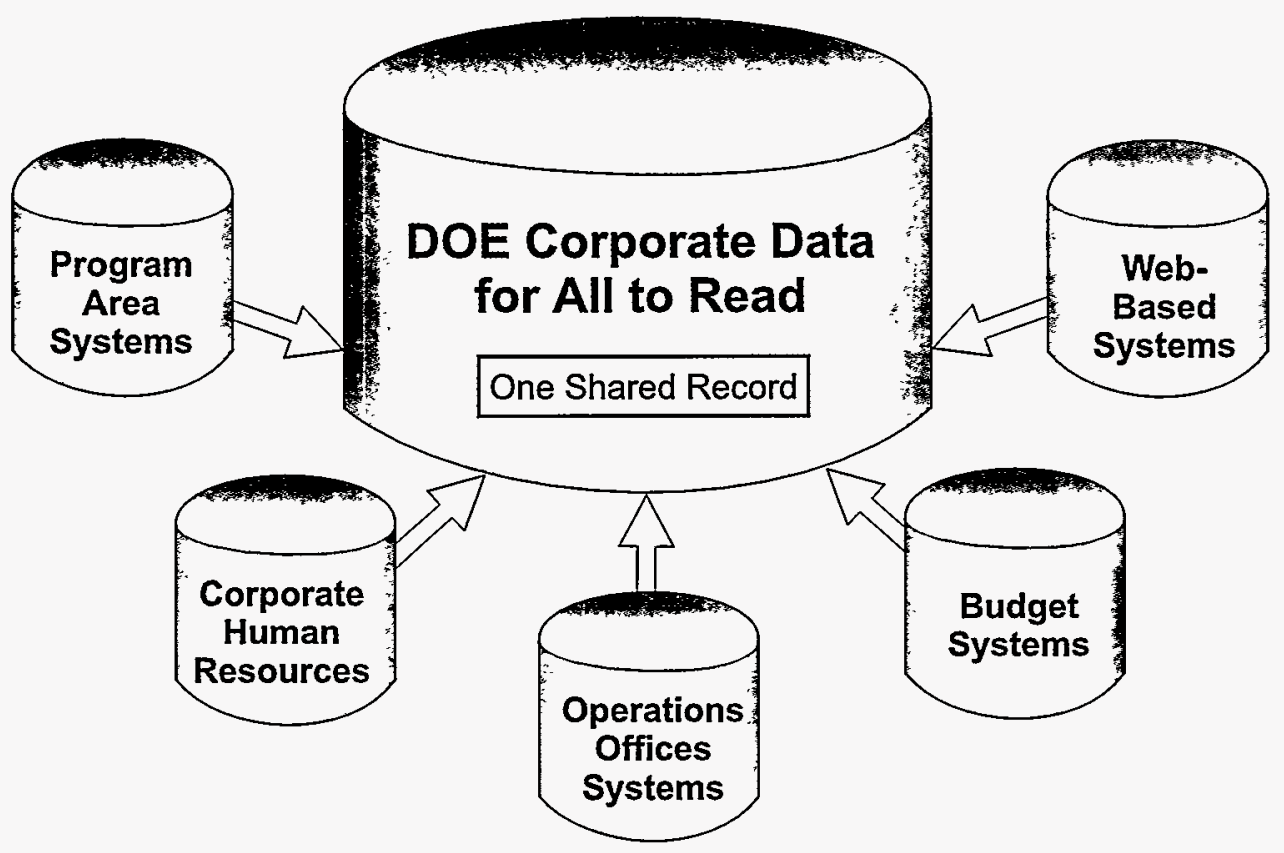




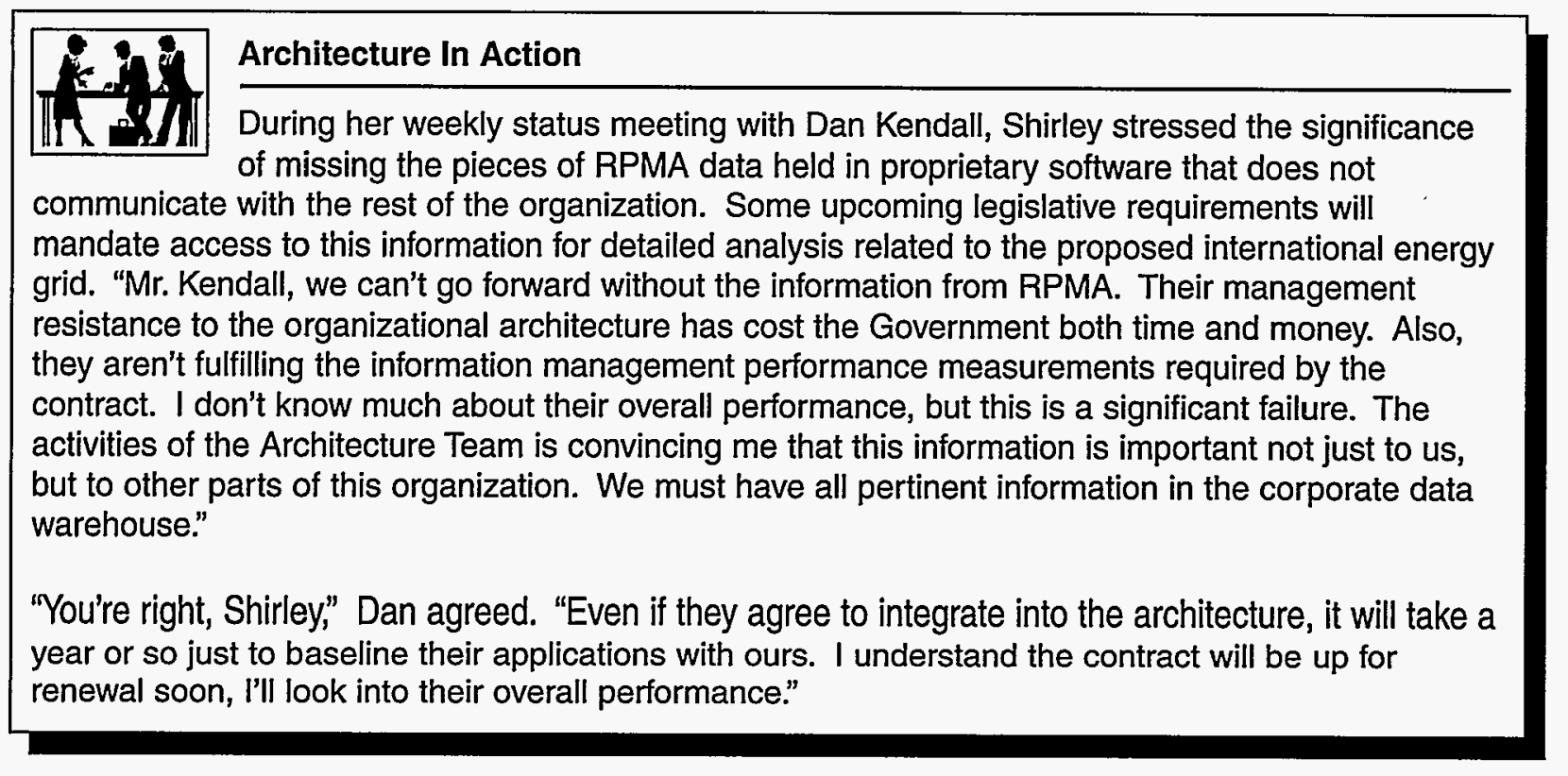

\section{Information Resources Catalog (IRC)}

Building the database or catalog of existing and planned information systems, hardware, software, and communications connections across DOE validates the strategic approach for the team. The team uses this baseline of information to identify gaps in automated support for business activities.

The vast number of independent systems, with many duplications of data elements, underscores the value of corporate planning and data sharing. Questionnaires, interviews, and information technology (IT) resources are utilized to develop this catalog of data on systems and technologies in place across the DOE enterprise. Detailed information is gathered by all Program Elements about formal organizationwide systems, plus workgroup and small end-user systems. Along with other key information, data is captured about system functionality and how data is received. Hardware, software, and communications platforms are also included in the catalog to describe the technical environment. Current technologies are described along with plans for upgrades. 
The IRC is a valuable centralized repository and primary tool for planning and is updated continuously by architecture teams across the enterprise. The baseline provides information to identify where corporate data is being shared and documents the platforms that may interfere with interoperability and data sharing. Identifying independent development efforts provides information about hidden costs and duplicate efforts across the enterprise.

\section{Applications Architecture}

The applications architecture defines the set of automated capabilities, or applications, needed to support business activities and provide access to data. Application projects are identified in terms of interrelationships between business functions and data.

The team reviews the current business and data models. Further review of table 4-2, Business Activities to Data Entities Matrix, shows that the systems that create data related to electricity production are required before systems that manage data about sales or consumption. This illustration of data dependency may affect the priority for application projects.

A review of the $\mathbb{R C}$ identifies that systems that create and manage data related to electricity generation and fuel type are widely available through the World Wide Web. Migrating these systems to meet criteria for architected systems is one project in the migration plan. All necessary data are identified to support the business lines before applications needed to manage the data can be defined. Existing applications are evaluated to determine what can be used and what is still needed.

Application projects are prioritized according to several criteria.

Cost efficiency based on data dependency. DOE commits to building data-creating applications before building data-using applications.

Business priorities plus factors for productivity improvement, customer service, existing systems, and probability of success (e.g., Corporate Guidance). 
Mandatory requirements, such as legal compliance, or executive mandates.

Technology infrastructure in place to support applications.

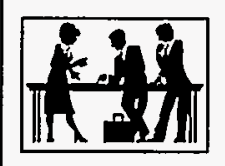

\section{Architecture In Action}

In preparing a master list of organizational applications, the Architecture Team members identified automated capabilities within their suborganizations that support business activities or access to data. The master list was sorted and prioritized to combine requirements that call for common functions. In the sequencing process, business and regulatory requirements take precedence organizationwide, influenced by technological and cost factors. Although Shirley brought a number of applications to the table, several dropped in organizational criticality. Although some of the Team members protested that their applications deserve higher ranking, Shirley understood the necessity of prioritizing requirements across the entire organization.

"We have to look at the data and functional requirements of this whole organization," she told a distraught Dan Kendall a few days later. "If we are talking about architecture, we are talking about what the business does, what data needs are, and how we want these things to be put together. The placement of the electricity production application so far down on the list is based on what this organization as a whole is doing. This piece is ours alone and, right now, it doesn't have enough critical elements in place to make it a viable project. For one thing, the legislative guidance for this project is just now being developed. The technology isn't available yet, and we just don't have access to all the needed information. We must have access to RPMA's nuclear power generation information to project how the plant retirements will affect cost and availability of electricity;" Shirley explained.

"For the $\$ 750,000$ being spent on that proprietary software they are developing, RPMA could have architected their entire organization and brought it in conformance with the rest of the Department," Dan replied. "In all likelihood, based on their past performance, the current M\&O will be eliminated from the recompete as not technically qualified. I have asked the Contracting Officer to make sure that the Request for Proposal includes architecture requirements as performance measures. We should be able to directly access to the RPMA information by the time the rest of the pieces come together for the system requirements."

Applications architecture provides tools to save money and time in development efforts through enterprisewide standards for development and configuration management, warehouse storage of shareable data, preference for commercial products, and a planned schedule based on technical and infrastructure projects. Automated estimating tools, in combination with an experienced development team, support the cost-estimating process.

In defining capabilities, the focus is on the business activities of the program responsible for energy production. In reality, this architectural example would be part of a larger enterprisewide stream of applications required to support the business of DOE Headquarters and its sites.

Table 4-3, Prototype Application Project Matrix and Scoring, is an example of the applications to be combined into technology projects on a master schedule. The priority score measures 
productivity, customer service, application size and complexity, and technology requirements. Technology architectures provide the strategy for scheduling application development as an integral part of the planning and implementation cycle.

\begin{tabular}{|c|c|c|c|c|}
\hline \multicolumn{5}{|c|}{ Table 4-3, Prototype Application Project Matrix and Scoring } \\
\hline Project & Application & Description & $\begin{array}{l}\text { Priority } \\
\text { Score } \\
\end{array}$ & Status \\
\hline Electricity & Production & $\begin{array}{l}\text { Creates data related to } \\
\text { electricity generation methods, } \\
\text { quantities, and fuel types. }\end{array}$ & 300 & $\begin{array}{l}\text { \# X in Development } \\
\text { Plan }\end{array}$ \\
\hline Electricity & Model, Formula & $\begin{array}{l}\text { Creates data containing } \\
\text { formulas for generation and } \\
\text { distribution models. }\end{array}$ & 280 & $\begin{array}{l}\text { \# X in Development } \\
\text { Plan for Program }\end{array}$ \\
\hline Electricity & $\begin{array}{l}\text { Sales and } \\
\text { Consumption }\end{array}$ & $\begin{array}{l}\text { Tracks actual sales based } \\
\text { upon consumed quantities and } \\
\text { application of specific models } \\
\text { to generate sales totals. }\end{array}$ & 260 & $\begin{array}{l}\text { \# X in Development } \\
\text { Plan for Program }\end{array}$ \\
\hline $\begin{array}{l}\text { Executive } \\
\text { Information } \\
\text { System }\end{array}$ & $\begin{array}{l}\text { Trends and } \\
\text { Analysis }\end{array}$ & $\begin{array}{l}\text { Crosscuts data from multiple } \\
\text { applications to provide } \\
\text { executive level rollup of detail } \\
\text { from applications above. }\end{array}$ & 80 & $\begin{array}{l}\text { \# X in Development } \\
\text { Plan for Program }\end{array}$ \\
\hline $\begin{array}{l}\text { Human } \\
\text { Resources }\end{array}$ & People & $\begin{array}{l}\text { Creates data on employees, } \\
\text { contractors, and all persons of } \\
\text { interest to DOE. Includes } \\
\text { name, phone, e-mail address, } \\
\text { etc. }\end{array}$ & 400 & $\begin{array}{l}\# X \text { in Corporate } \\
\text { Development Plan }\end{array}$ \\
\hline $\begin{array}{l}\text { Human } \\
\text { Resources }\end{array}$ & Expertise & $\begin{array}{l}\text { Creates data on knowledge, } \\
\text { skills, and abilities related to } \\
\text { business functions of the } \\
\text { enterprise. }\end{array}$ & 360 & $\begin{array}{l}\text { \# X in Corporate } \\
\text { Development Plan }\end{array}$ \\
\hline $\begin{array}{l}\text { Document } \\
\text { Management }\end{array}$ & $\begin{array}{l}\text { Electronic } \\
\text { Document } \\
\text { Library }\end{array}$ & $\begin{array}{l}\text { Creates data related to } \\
\text { correspondence and other } \\
\text { documents stored in central } \\
\text { repository. }\end{array}$ & 320 & $\begin{array}{l}\# X \text { in Corporate } \\
\text { Development Plan }\end{array}$ \\
\hline $\begin{array}{l}\text { Document } \\
\text { Management }\end{array}$ & $\begin{array}{l}\text { Electronic } \\
\text { Routing/ } \\
\text { Concurrence }\end{array}$ & $\begin{array}{l}\text { Creates data related to } \\
\text { tracking editing and approval } \\
\text { cycles. }\end{array}$ & 315 & $\begin{array}{l}\text { \# X in Corporate } \\
\text { Development Plan } \\
\text { Needs Digital } \\
\text { Signature for } \\
\text { Electronic Concurrence }\end{array}$ \\
\hline
\end{tabular}


The scoring model described and illustrated in table 4-3 defines the cost-effective sequence for development. Business priorities are then used to sequence the applications for development. The ranked lists are consolidated and adjusted in a final step to ensure that the final sequence is a strategic initiative. Figure 4-3, Sequencing Example, shows the steps to be taken after determining a cost effective sequence.

Figure 4-3, Sequencing Example

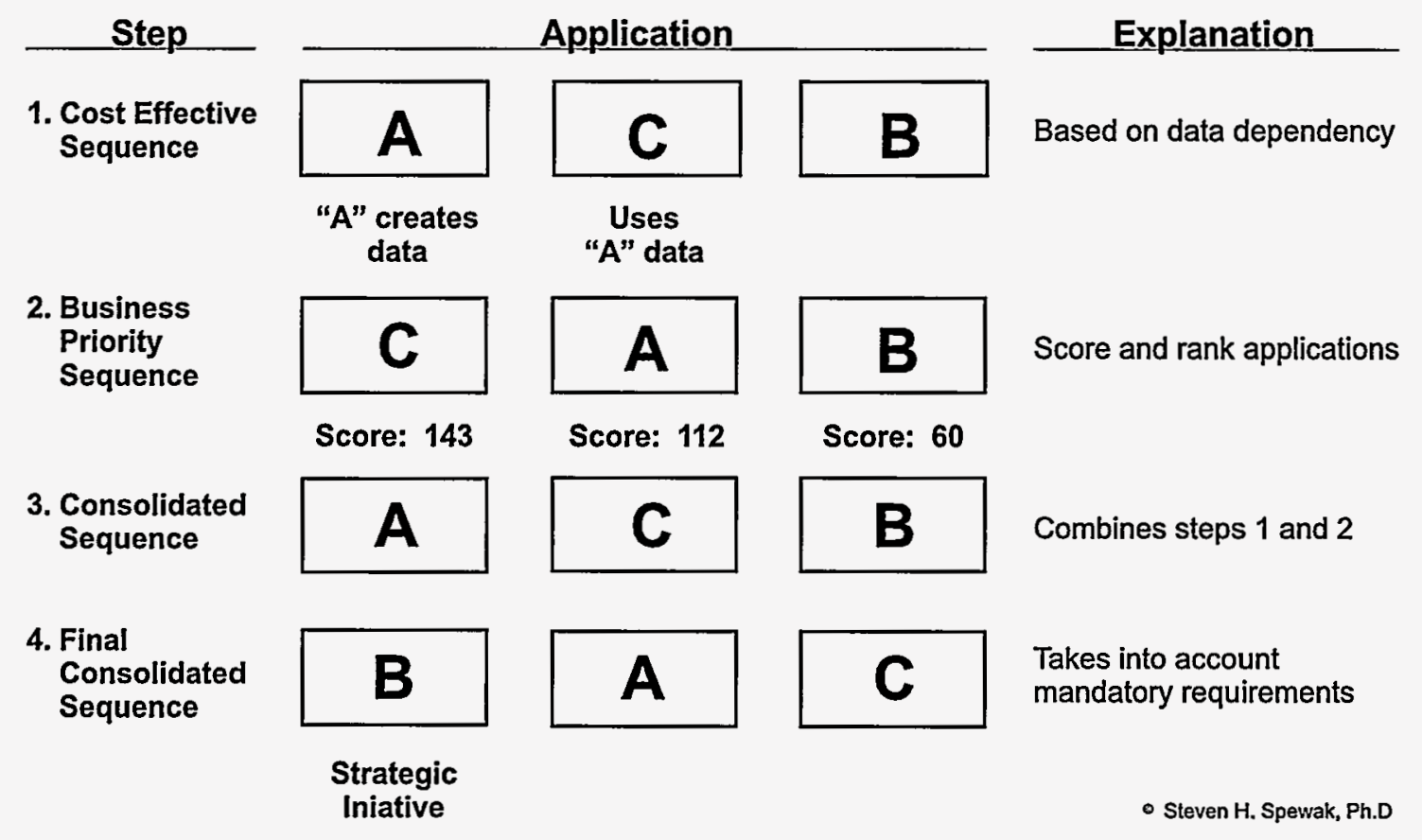

\section{Value of Applications Architecture}

Figure 4-4, Challenge of Sequencing, illustrates that agreement and commitment to an organized plan for application development and implementation will not be easy. Working through the process in an orderly fashion as described above offers an approach that is rigorous, yet adaptable. 
Figure 4-4, Challenge of Sequencing

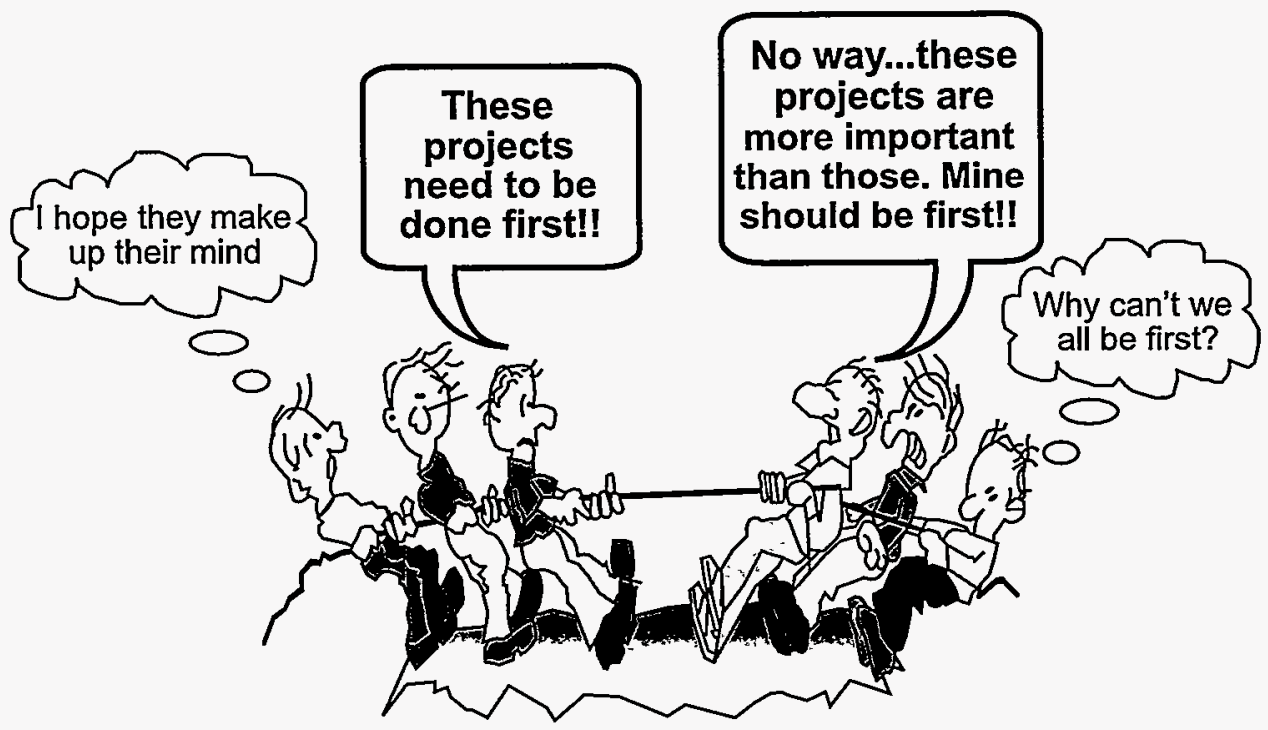

Architected applications reflect the Department's movement away from an environment of stovepiped, non-data-sharing systems to an environment where data requirements of the enterprise are addressed. Planning costs and other resources for short- and long-term are enhanced by a plan for building applications based on data and business needs. There are fewer surprises or emergency development efforts.

Applications architecture benchmarks enterprisewide analysis of automation needs. Because applications focus on managing shared data, they remain valid even if business organizations or processes change.

\section{Technology Architecture}

The infrastructure to support business activities, data, and applications defined in the other architectures constitutes the technology architecture. The migration from a technology-driven change process to business-needs and data-driven information planning is the hallmark of the architectural process. Technology serves business and mission operations and provides the foundation for applications and data to ensure success. 


\section{Value of Technology Architecture}

Technology architecture is used for the following purposes.

Select and deploy new information technologies

Avoid technology obsolescence

Assure that resources are used efficiently

Plan what technologies are to be deployed to support applications

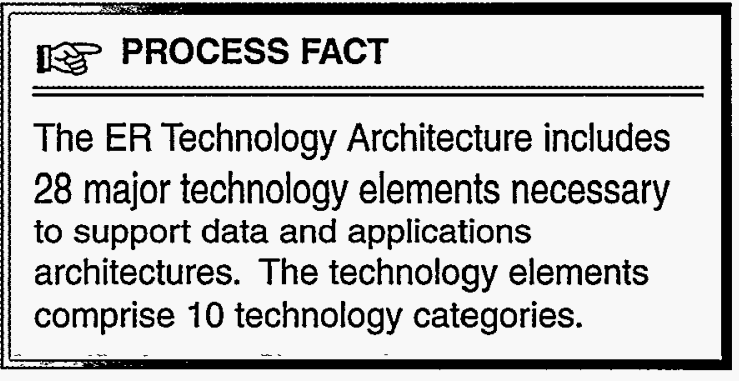

The technology architecture is developed through the following steps.

Research Technical Topics

Develop Technology Position Statements

Develop Scores and Rank Technologies

Develop the Technology Deployment Plan

Using the work of DOE business and information leaders and industry resources, the architecture team researches trends and specific technologies to support technical infrastructure projects as well as architected applications.

\section{Model for Technology Position Statements}

Technology position statements include a vision and implementation strategy for supporting essential topics, such as standard exchange of electronic documents across the enterprise or access to a repository of current and historical DOE positions and testimony. This high-level strategic view maps what technology elements need to be in place over the next 5 years to support the other architectures.

Statements examine technical components of the current technology baseline and compare them with technology trends both near-term and longer-term. Each position includes the following statements and implications and dependencies.

\section{Vision Statement}

Current Baseline Environment

Near-term Deployment (1-18 months)

Strategic Direction (4-6 years) 


\section{Execution Statement}

Mainstream Support

Retirement and Containment Targets

Feasibility Target

Emerging Technology

Implications and Dependencies

\section{Principles}

Industry Position

$\square$ DOE Baseline Description

$\square$ DOE Application Architecture

Figure 4-5 illustrates the format of a summary of technology positions.

\section{Figure 4-5, Summary of Technology Positions}

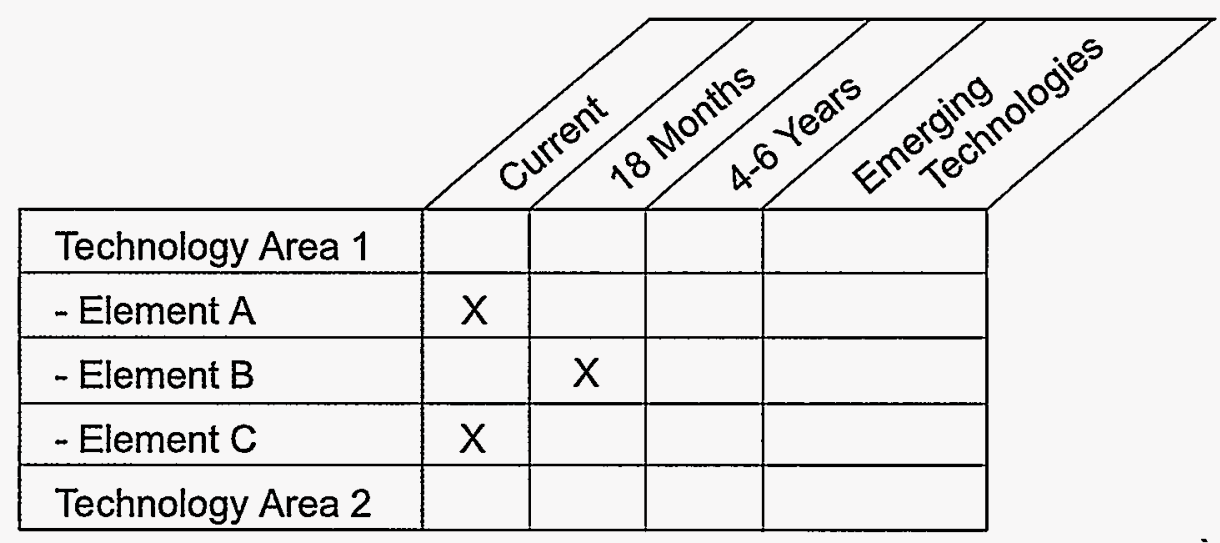

The team formulates the technical projects in relationship to the architected applications. The projects are scheduled in relationship to needs of planned applications. Many technical projects require evolving standards and infrastructure requirements to support the deployment of an application. Network upgrades, for example, increase transmission speed and reduce bottlenecks for increased network traffic.

Technology architectures provide a strategy for scheduling application development projects as an integral part of the planning and implementation cycle and ensure that the appropriate technologies are in place at the right time. 


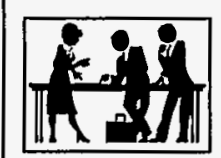

\section{Architecture In Action}

Based on information gathered throughout the architecture process, the Team developed an implementation plan that addressed current organizational priorities. The project was far from over, however; the implementation was the beginning of a philosophy of planning that needed to be institutionalized. The ongoing process includes reviewing and prioritizing planned applications, updating the resources baseline, developing and maintaining performancebased measures, building architectural and technology principles, and ensuring organizationwide buy-in to adopted standards and plans. In addition, the organization built an information architecture toolset that includes a data dictionary, data modeling tool and methodology, common development approach, value metrics planning tool, and data repositories that run with background databases.

The RPMA contract was awarded and the new contractor agreed to comply with the Departmental architecture; the organizational architecture was updated in a 6-month process. Shirley finally had access to all the pieces of information needed to work on her organization's strategic goals. She told Dan Kendall, "I know the organization has put together an information architecture that will be able to deliver what we need. We are fully compatible, our field locations are included, and external organizations we deal with will be reachable, too. We are on the way to having just what we need."

In 1998, Shirley's organization began work toward the Department's strategic goal of developing and promoting sustainable, secure, environmentally sound, and competitive energy systems. During this time, Shirley's staff completed the development of modeling and analysis capabilities to guide the design of related legislation. By 2001, various legislative options have been designed, and several have been selected as pilot programs to prove their relative viability. The Department became aggressive in establishing publicly acceptable initiatives to solve national and international electrical energy issues. By 2004, the information architecture implementation is well underway, and a preliminary international agreement has been reached proposing an international electrical grid.

\section{Implementation Plan and Migration Strategy}

The implementation plan and migration strategy provides a strategic, 5-year view of project deployment and resources levels and includes the following.

Transition projects - to prepare for organizational implementation

System development projects - to build capabilities for business activities in a shared-data environment

Technology projects - to build necessary infrastructure and implement necessary technology elements

Figure 4-6 illustrates information architecture's enhancement to the DOE strategic planning model. Architectural components display in shaded cells with the Business Model as the keystone for the planning process. 


\section{Figure 4-6, Adding Information Planning to Other DOE Planning}

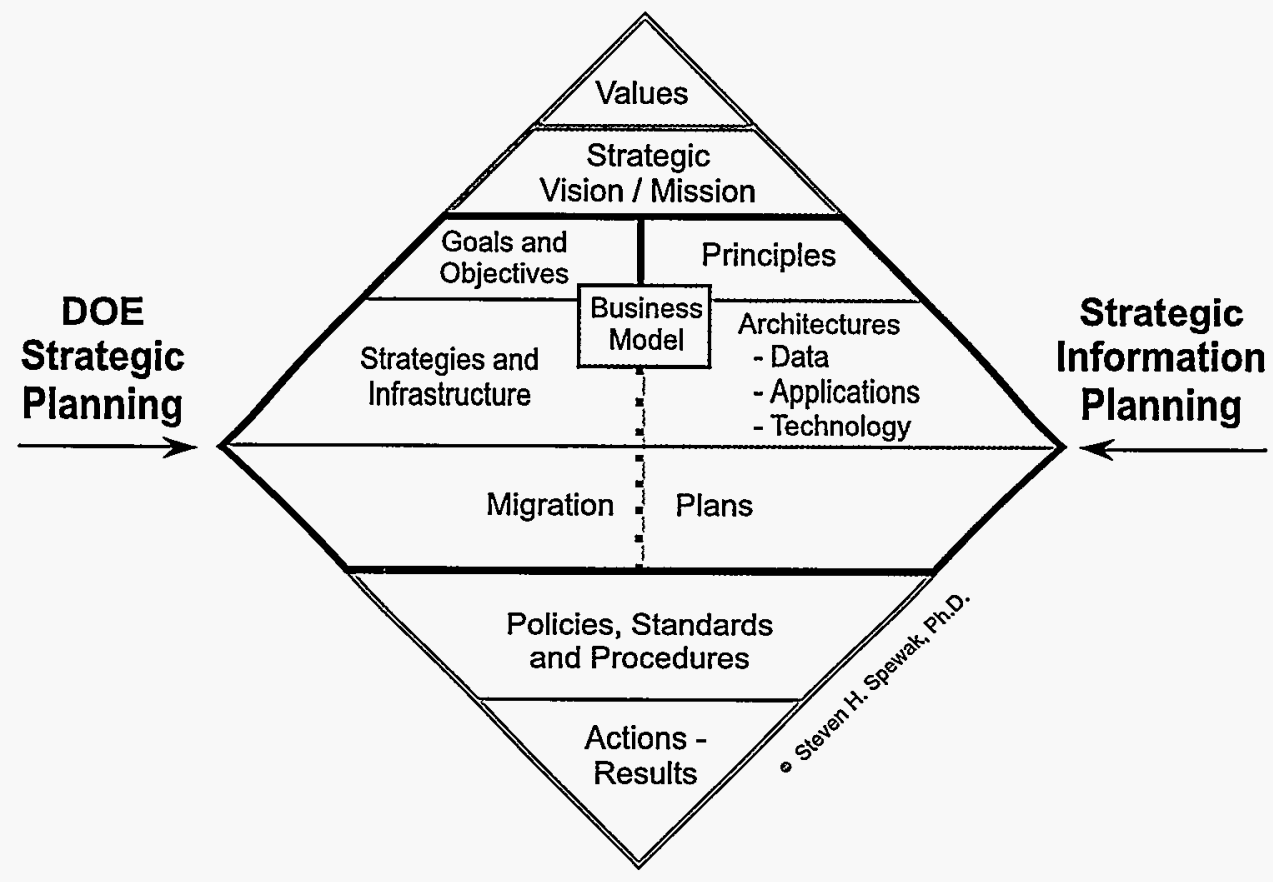

A fundamental premise of an architected environment is that currently active projects are included in the migration plan and meshed with new applications and technology projects in the scheduling. The following plan model (figure 4-7) schedules transition projects, technology projects, and applications to ensure that the right elements are in place at the right time.

Figure 4-7, Migration Plan Example

\begin{tabular}{|c|c|c|c|c|c|c|c|c|}
\hline ID & Task Name & 1998 & 1999 & 2000 & 2001 & 2002 & 2003 & 2004 \\
\hline 1 & Enhance Existing System 1 & $=$ & & & & & & \\
\hline 2 & Transition Project 1 & & & & & & & \\
\hline 3 & Transition Project 2 & & & & & & & \\
\hline 4 & Technology Project 1 & & & & & & & \\
\hline 5 & Technology Project 2 & & & & & & & \\
\hline 6 & Technology Project 3 & & & & & & & \\
\hline 7 & Develop System 1 & & & & & & & \\
\hline 8 & Develop System 2 & & & & & & & \\
\hline 9 & Develop System 3 & & & & & & & \\
\hline
\end{tabular}


Transition projects, such as network infrastructure and enhanced e-mail, must be completed before the planned enhancement and new applications can be developed and deployed. Business leaders commit resources to support the plan, which they understand because they were a part of the process. The plan meets critical business needs and schedules projects to ensure that applications and technology work together. It provides accurate cost estimates, supports planning of resources, and accounts for dependencies among projects.

\section{DROCESS FACT}

The EAP process executed in ER produced a detailed migration plan for deployment of architected applications and technology over the next five years. Accompanying the plan was a set of nine recommendations to enable and facilitate accomplishment, and for instituting an ongoing architectural process in ER, one of the four largest DOE Program Offices.

\section{ing}

\section{Architecture In Action}

In February 2005, Shirley has been tasked to bring to closure the activities related to Objective 2 of the Energy Production portion of the Strategic Plan. This objective states, "ensure that a competitive electricity generation industry is in place that can deliver adequate and affordable supplies with reduced environmental impact." Part of this achievement is the drafting of proposed legislation supporting an openly competitive electricity system. The legislation has International impacts. Since 1997, Shirley's organization has created a modeling capability, performed the analyses, and designed and piloted several legislative options.

In the last few years, the information architecture has been put in place and is being regularly maintained and updated. All of the pieces are in place for Shirley to fulfill strategic requirements by measuring the success of the pilots against specific performance metrics. She can now develop a system to monitor the impact of the piloted options. She has multiple performance metrics to gather from a variety of contributors. Options will be compared on quantifiable measurements of fossil fuel use, scientific advancement, environmental quality, ES\&H incidents, competitiveness, and public confidence.

Using the skills matrix in the human resources repository, Shirley assembles a team of information management, technical, and business specialists; each has a critical set of information technology enablers essential to the successful completion of the project. Sam Lui has been a member of Shirley's workgroup for several years; he has identified and quantified the performance metrics. Christie Craig is an architecture expert located at Oceanside Power Marketing Administration; she can link the metrics to data in the corporate warehouse or accessible from disparate external information sources. Jon Peterson is a top-notch system developer from Parklawn National Laboratory; he can create a system that will manipulate the data into meaningful measurements and analyses. 


\section{Conclusions}

\section{Cultural Outcomes of the Architectural Process}

Architected environments have cultural characteristics, which differ from unarchitected environments. Figure 5-1 illustrates the contrast between environments depending on the architectural maturity of the organization.

Figure 5-1, Cultural Characteristics

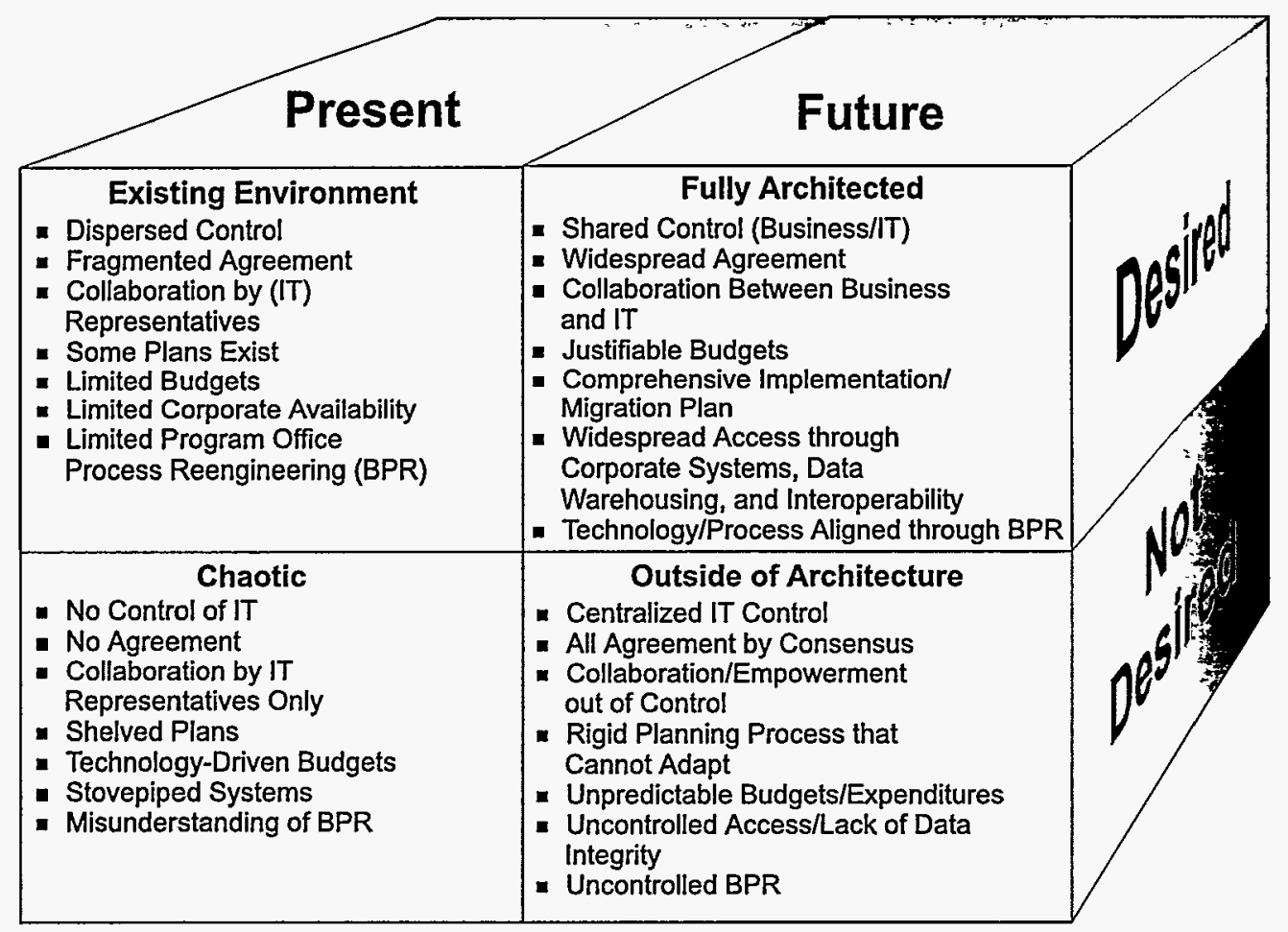

Information technology (IT) decisions are vested in an organizational environment that shares control between IT and business leaders. The level of buy-in to the architectural process varies throughout the organization, and collaborating meaningfully assists in fulfilling business needs. An ongoing planning process with justifiable budgets allows tactical IT deployment to meet strategic needs. Access to information is improved and less jealously guarded. At this point, the organization can embark on fundamental process reengineering, not to eliminate positions, but to do more with less through the architected environment. 
In the discussion that follows, the desirable cultural characteristics for the future of a fully architected environment are presented.

In a culture where business leaders share control with the information management leaders, better decisions result in supporting business and customer needs. Business executives understand the business processes, while IT representatives provide the technical knowledge essential to making sound decisions.

A widespread level of agreement or buy-in by key decision makers is an essential ingredient in the mature architected enterprise. Managers and other participants demonstrate their commitment to the principles that support the process as well as the expected benefits by the encouragement and leadership they offer at different stages of the process.

Workgroups skilled in collaboration strategies are a major outcome of the architecting process. Collaboration skills are developed as teams work closely to populate toolsets and conduct research as part of the process. They review charts of functions, agree on the vocabulary of work processes and data entities, and, ultimately, sequence many projects for a major plan. Teamwork offers development opportunities and creative approaches to tasks that ultimately result in excellence that marks the work of an effective team.

As all effective project managers know, plans are useful only if they can be adjusted to respond to a rapidly changing world. Ongoing planning is a major outcome from architecture planning. The initial migration plan describes a schedule and estimated costs for projects sequenced by priority and technology readiness. The plan is continuously updated as priorities change, technology matures faster or slower than predicted, or other factors intervene.

The shared control by business and technical leaders results in a positive cultural change for budgets. An integrated approach that results in a plan clearly understood by the business people, as well as the technical people, provides the tool for effective budget formulation over a much longer timeframe (5-7 years). New tools offer help in estimating the cost of technical projects, based on the necessary infrastructure being in place. Leaders have the information to justify both planned costs and expenditures because they collaborate in appropriate funding decisions. Collaboration and shared control will result in effective stewardship of the technology and information assets of the organization.

Access to information when and where needed is a primary outcome of the architected environment. Availability is balanced with sound access controls and other security tools to safeguard the organization's information. Data warehouses and data dictionaries provide custodial control of data that can be accessed by different systems. Corporate systems that are built from modular components and share data used by different systems reduce the number of redundant and stovepiped systems. 
An environment that encourages effective analysis of business processes to align them with both good business practices and technology planning is the optimum impact of improved process reengineering. Workgroups empowered to improve the quality of their services and products are recognized throughout the organization as centers of excellence.

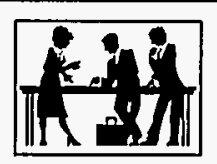

\section{Architecture In Action}

Shirley e-mails the group members the status of the pilot projects and preliminary metric, system, and data requirements. The participants research their portions in advance of the planning session and post materials to common access electronic storage for premeeting review. Meeting via desktop videoconference, Shirley provides additional project information. "Measuring energy efficiency improvements, production levels and productivity, and energy prices are key elements to recommending legislative actions supporting the competitiveness initiative and the international electrical grid. In the past, collecting and analyzing this data would have been costly and time-consuming. Our organization's information architecture allows us access to a great deal of information and the flexibility to use it creatively to meet mission requirements. I'm hoping we can exchange project information effectively during this session, determine the next steps towards making this analysis system a reality, and realize our goal of presenting a recommendation to Congress in 60 days. Let's go over what you've already found." As the read-ahead materials scroll through a window on the monitor, Jon, Christie, and Sam review their findings.

Shirley is pleasantly surprised that so much information is already available through existing applications in the architecture. Her system is virtually architected; portions were developed during the options modeling and analysis phase, the technology was put in place, and relevant data was included in the toolset along the way. The development team collects the missing pieces over the next week, and the collaboration system allows each participant to comment in real time on every point being developed. This approach cuts the initial development process to less than 2 weeks. Jon has already identified segments of reusable code that can be linked together quickly to build the system front-end. In addition, he suggests the use of a newly implemented standardized Net broadcast facility that would allow Shirley to produce weekly status briefings that could be viewed by Mr. Kendall and others at their convenience.

On the day after Dan Kendall presents recommended legislation to Senator Margaret Flynn-Horton, Shirley calls Ray Saunders. "Once again, I have to tell you how impressed I am with the results of the information architecture. I asked for a group of capabilities that I thought would provide the minimum to allow us to do this project on time, but I also got management briefings and a lot of other bonuses more quickly and for less money than l'd planned. You've told me before that the purpose of architecting is to ensure proper alignment among technology, systems, and business processes. My system and others in this architecture are puzzle pieces that fit together to support the Department's mission. I like it!" 


\section{Recommendations}

Many organizations develop elaborate architectures without the benefit of buy-in from the business community. No organization is truly architected unless their business needs are being met. Typically, organizations are unable to successfully reengineer to meet competitive challenges. A strategically directed and architected process replaces the imbalance caused by short-term tactical IT initiatives.

The Association for Federal Information Resource Managers (AFIRM) performs an annual survey of the Federal Agency Chief Information Officers (CIOs) asking for their top ten challenges. Previously, information architecture had ranked third. This year's results, published in December 1997, named information architecture as the top challenge facing Federal Agencies.

The leading industry analysts-the Gartner Group-recognize the value of IT architectures as an extension of the business strategy. Gartner has adopted the five-layer model consisting of business, information, data, applications, and technology architectures.

Information architecture is an ongoing process, not a static, shelved plan. To make the process live on after defining initial architectures, a management structure must be put in place that allows information and policy decisions to flow through rules that guide the adoption and implementation of new initiatives. The adoption of a governing mechanism for the process, a cognizant official, and repositories of architectural information are the key components to ongoing success.

The overview plan for executing a Department of Energy (DOE) Headquarters corporate systems Enterprise Architecture Planning process is contained in appendix E, Plan for DOE Headquarters Corporate Systems Architecture. Execution of this process will assist in aligning the integrated DOE business systems environment enabling sites and Headquarters Offices to

become interoperable.

Achieving the DOE Architectural Vision is a key component for success into the next century. Moving the architectural process forward in accordance with legal mandates offers a unique opportunity for DOE leadership in the Federal sector. 


\section{Appendix A}

\section{Prototype Business Model}





\begin{tabular}{|c|c|}
\hline \multicolumn{2}{|r|}{ Prototype Business Model } \\
\hline Business Function & Description \\
\hline Promote DOE & $\begin{array}{l}\text { - Market the benefits of business areas to the public, Congress, and } \\
\text { President } \\
\text { - Provide answers and comments to requests from the public and private } \\
\text { sectors following guidelines provided by the Freedom of Information Act } \\
\text { (FOIA) and Openness Advisory Panel } \\
\text { - Publicize achievements and progress in all business areas } \\
\text { - Manage award programs, media recognition, and other tools to recognize } \\
\text { business success }\end{array}$ \\
\hline Manage Funds & $\begin{array}{l}\text { - Review budget plans and develop master plan for funding decisions } \\
\text { - Develop and manage budget process schedule to ensure success in } \\
\text { meeting all targets, including consolidation and verification of all } \\
\text { program/site budgets, production of budget documents, budget cross-cut } \\
\text { data, and the appeals process } \\
\text { - Distribute and track funds } \\
\text { - Reconcile actual obligations and costs with plans }\end{array}$ \\
\hline Set Policy Direction & $\begin{array}{l}\text { - Manage business development activities } \\
\text { - Manage Departmental quality and standards programs to ensure that } \\
\text { - Mansential mandates are met } \\
\text { missions, goals, strategies, and indicators of success } \\
\text { - Manage program to review high-level objectives, milestones, and } \\
\text { performance assessment based on standards-based implementation plans } \\
\text { developed for every business unit } \\
\text { - Provide oversight and planning guidance to partners } \\
\text { - Manage initiatives as they contribute to the Departmental position on } \\
\text { guidance, policies, and procedures for support for all business areas } \\
\text { - Provide guidance and oversight to facility and project planning activities } \\
\text { - Coordinate assessment of success indicators, performance measures, } \\
\text { goals, and other standards to determine progress toward meeting } \\
\text { objectives }\end{array}$ \\
\hline
\end{tabular}




\begin{tabular}{|c|c|}
\hline \multicolumn{2}{|r|}{ Prototype Business Model } \\
\hline Business Function & Description \\
\hline $\begin{array}{l}\text { Office Management } \\
\text { and Administration }\end{array}$ & $\begin{array}{l}\text { - Manage document control of designated documents to determine access } \\
\text { rights and physical control procedures while supporting the Secretary's } \\
\text { mandate for openness and interoperability } \\
\text { - Manage the document lifecycle (creation, concurrence, distribution, and } \\
\text { retirement) by capturing and protecting the information as an asset to be } \\
\text { reasonably available to customers and stakeholders } \\
\text { - Manage all aspects of travel function, including authorization, budget, } \\
\text { arrangements, and expense reconciliation } \\
\text { - Manage designated records as part of a document management process } \\
\text { that maintains "intellectual control" over unclassified and classified records } \\
\text { while supporting maximum openness and appropriate access } \\
\text { - Manage the concurrence and approval process to provide timely, quality, } \\
\text { and politically correct work products through appropriate review and } \\
\text { revisions as required by those with signature authority } \\
\text { - Arrange logistic meeting support, which may including videoconferencing, } \\
\text { communication systems, translation services, copiers, recording equipment, } \\
\text { web-site links, and facilitation } \\
\text { - Maintain records of calls, letters, e-mail, meetings, and conversations }\end{array}$ \\
\hline $\begin{array}{l}\text { Programmatic } \\
\text { Oversight }\end{array}$ & $\begin{array}{l}\text { - Manage current and potential work } \\
\text { - Manage the proposal generation process including solicitation, advertising, } \\
\text { selection criteria, guidance, receiving and logging in proposals } \\
\text { - Review and select work based on merit of existing work, recommendations } \\
\text { from reviewers, and goals and selection criteria } \\
\text { - Notify institution of decision and determine funding vehicle } \\
\text { - Provide liaison among appropriate institutions to coordinate allocation of } \\
\text { non-financial resources such as equipment loans and transfers, facilities, } \\
\text { supercomputer time } \\
\text { - Evaluate work productivity and quality according to guidelines provided and } \\
\text { make recommendations for improvement } \\
\text { - Define the assessment scope, process, evaluation criteria, and identify } \\
\text { reviewers } \\
\text { - Receive and review findings/recommendations and maintain records } \\
\text { - Ensure the vitality of the Department's national security enterprise } \\
\text { - Ensure secure and competitively priced energy services } \\
\text { - Reduce environmental impacts from all fossil fuels } \\
\text { - Resolve nuclear waste disposal issues } \\
\text { - Protect public health and the environment by understanding and reducing } \\
\text { the environmental, safety, and health risks and threats from DOE facilities } \\
\text { - Work closely with other Federal Agencies to tackle the major scientific and } \\
\text { technological challenges facing the Nation } \\
\text { - Develop technologies required to meet DOE energy, national security, and } \\
\text { environmental quality goals }\end{array}$ \\
\hline
\end{tabular}




\begin{tabular}{|c|c|}
\hline \multicolumn{2}{|r|}{ Prototype Business Model } \\
\hline Business Function & Description \\
\hline $\begin{array}{l}\text { Manage Human } \\
\text { Resources }\end{array}$ & $\begin{array}{l}\text { - Plan for future human resource requirements and monitor current } \\
\text { deployment of staffing resources } \\
\text { - Manage the staffing process for internal and external candidates, using } \\
\text { position announcements, reviewing applications, interviewing, and selection } \\
\text { activities } \\
\text { - Manage performance evaluation program through the use of standards, } \\
\text { development needs, recognition programs, and corrective and disciplinary } \\
\text { actions } \\
\text { - Manage training program, including mandatory training and professional } \\
\text { development opportunities } \\
\text { - Manage program to maintain repository of updated mission and functions } \\
\text { statements for all program and organizational units, including hierarchical } \\
\text { structure and reporting relationships } \\
\text { - Assign people to work, including location, schedule, and account for daily } \\
\text { hours and absences } \\
\text { - Investigate accidents and injuries to employees and identify improvement } \\
\text { needs } \\
\text { - Create an environment where teamwork, trust, openness, pride, and } \\
\text { respect are standard practices, and excellent performance is rewarded } \\
\text { - Provide meaningful work opportunities and implement innovative } \\
\text { compensation and personnel initiatives to attract and retain a diverse and } \\
\text { well-trained workforce }\end{array}$ \\
\hline Manage Facilities & $\begin{array}{l}\text { - Manage the facilities operations program, including maintenance, space } \\
\text { allocation and moves } \\
\text { - Fulfill requests for equipment, furniture, telephone, office, and space } \\
\text { - Maintain inventories of equipment including furniture and telephones } \\
\text { - Design, construct, and operate facilities in a timely and cost-effective } \\
\text { manner } \\
\text { - Maintain security systems (i.e., badging, building access, vehicle tagging) } \\
\text { - Maintain communications and electronic equipment, office machinery, and } \\
\text { microcomputers } \\
\text { - Provide and manage custodial, roads, grounds, refuse, landfill, recycling, } \\
\text { and landscaping services } \\
\text { - Manage handling of hazardous materials } \\
\text { - Manage abatement/encapsulation, removal, storage, and disposal operations } \\
\text { - Manage civil, electrical, environmental, and mechanical engineering } \\
\text { services }\end{array}$ \\
\hline
\end{tabular}




\begin{tabular}{||l|l||}
\hline \multicolumn{2}{|c||}{ Prototype Business Model } \\
\hline Business Function & Description \\
\hline \hline Infrastructure & $\begin{array}{l}\text { - Ensure the safety and health of workers and the public } \\
\text { - Protect and restore the environment } \\
\text { - Maintain nuclear explosive and weapons surety programs } \\
\text { - Adhere to technical standards } \\
\text { - Communicate information and build trust within the organization and with } \\
\text { stakeholders and customers } \\
\text { - Identify and capture for preservation records of national, historical, or public } \\
\text { interest } \\
\text { - Provide stakeholders with easy access to the Department's records to the } \\
\text { extent consistent with National Security and privacy concerns } \\
\text { - Manage workforce } \\
\text { - Report fraud, waste, and abuse } \\
\text { - Allocate, spend, and account for resources } \\
\text { - Perform audit resolution and followup activities } \\
\text { - Coordinate General Accounting Office activities } \\
\text { - Procure, produce, and contract for goods and services } \\
\text { - Streamline and continuously improve operations } \\
\text { - Manage classified and unclassified computer security programs } \\
\text { - Protect and control safeguards and security interests } \\
\text { - Control and account for nuclear materials } \\
\text { - Track foreign travel authorizations }\end{array}$ \\
\hline - Define data, applications, and technology architectures to support business \\
- Allocate resources to information management (IM) projects to implement \\
the architectures \\
- Resolve user identified IM problems and needs \\
- Define application requirements including project scope and feasibility \\
- Acquire or design and develop applications \\
- Manage infrastructure to support IM program including acquisition and \\
installation of hardware and software, maintenance of wide area network \\
(WAN) telecommunications services among organizational entities, and \\
manage IM
\end{tabular}




\section{Appendix B}

\section{Corporate Applications Inventory}




$-\ldots \ldots-\ldots$




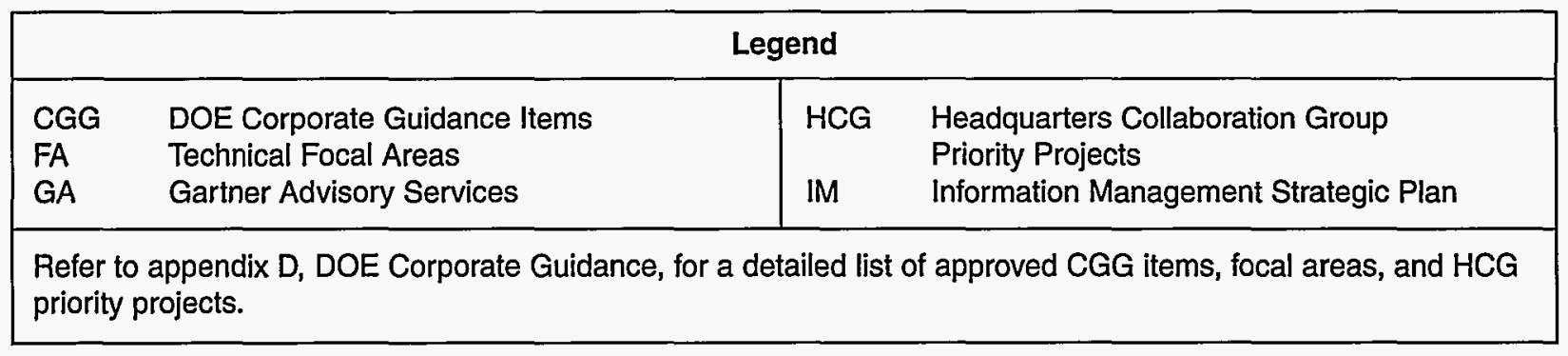

\begin{tabular}{|c|c|c|c|c|}
\hline \multicolumn{5}{|c|}{ Corporate Applications Inventory } \\
\hline Application & Description & Capabilities & Reference & Technology \\
\hline $\begin{array}{l}\text { Corporate } \\
\text { Human } \\
\text { Resource } \\
\text { Information } \\
\text { System } \\
\text { (CHRIS) }\end{array}$ & $\begin{array}{l}\text { Enterprisewide } \\
\text { system to automate } \\
\text { and streamline } \\
\text { human resource } \\
\text { business functions. } \\
\text { Collaborative effort } \\
\text { with contractors/ } \\
\text { field uses } \\
\text { Peoplesoft, a COTS } \\
\text { product. }\end{array}$ & $\begin{array}{l}\text { - Process personnel } \\
\text { actions } \\
\text { - Provide real-time } \\
\text { information } \\
\text { - What/lf Analysis } \\
\text { - Online reporting }\end{array}$ & $\begin{array}{l}\text { CGG } 0004 \\
\text { HCG } 3,7 \\
\text { IM \#1, 3, 5, } \\
6\end{array}$ & $\begin{array}{l}\text { - Modular } \\
\text { Components } \\
\text { - Data Warehouse } \\
\text { - LANMAN Telecom }\end{array}$ \\
\hline $\begin{array}{l}\text { Document } \\
\text { Online } \\
\text { Coordination } \\
\text { System } \\
\text { (DOCS) }\end{array}$ & $\begin{array}{l}\text { - Manages } \\
\text { document } \\
\text { creation, revision, } \\
\text { distribution, } \\
\text { storage, and } \\
\text { retrieval functions } \\
\text { - Electronic routing } \\
\text { - Scanned and } \\
\text { facsimile images } \\
\text { add to document } \\
\text { library for } \\
\text { searching }\end{array}$ & $\begin{array}{l}\text { - Capture paper } \\
\text { electronically } \\
\text { - Manage all } \\
\text { document formats } \\
\text { (text, images, } \\
\text { graphics) } \\
\text { - Flexible routing } \\
\text { - Audit trail }\end{array}$ & $\begin{array}{l}\text { CGG } 0009 \\
\text { CGG } 0010 \\
\text { CGG } 0020 \\
\text { CGG } 0021 \\
\text { CGG } 0236 \\
\text { CGG } 0239 \\
\text { HCG \#3,6 } \\
\text { IM \#3,6,7 }\end{array}$ & $\begin{array}{l}\text { - Modular } \\
\text { Components } \\
\text { - Desktop Platform } \\
\text { - Internet Access } \\
\text { - Network Computing } \\
\text { - LAN/WAN Telecom }\end{array}$ \\
\hline DOEInfo & $\begin{array}{l}\text { A repository of } \\
\text { database tables on } \\
\text { DOE Federal } \\
\text { workforce } \\
\text { information supports } \\
\text { data sharing in } \\
\text { multiple applications } \\
\text { (e.g., CHRIS, } \\
\text { Call-up). }\end{array}$ & $\begin{array}{l}\text { - Data steward } \\
\text { responsibility } \\
\text { - Common data } \\
\text { definitions } \\
\text { - Single source of } \\
\text { data } \\
\text { - Data sharing }\end{array}$ & $\begin{array}{l}\text { CGG } 0020 \\
\text { CGG } 0021 \\
\text { CGG } 0236 \\
\text { CGG } 0239 \\
\text { IM \#4,6 }\end{array}$ & $\begin{array}{l}\text { - Data } \\
\text { Warehouse/Marts } \\
\text { - Data Dictionary } \\
\text { - LAN/WAN Telecom }\end{array}$ \\
\hline
\end{tabular}




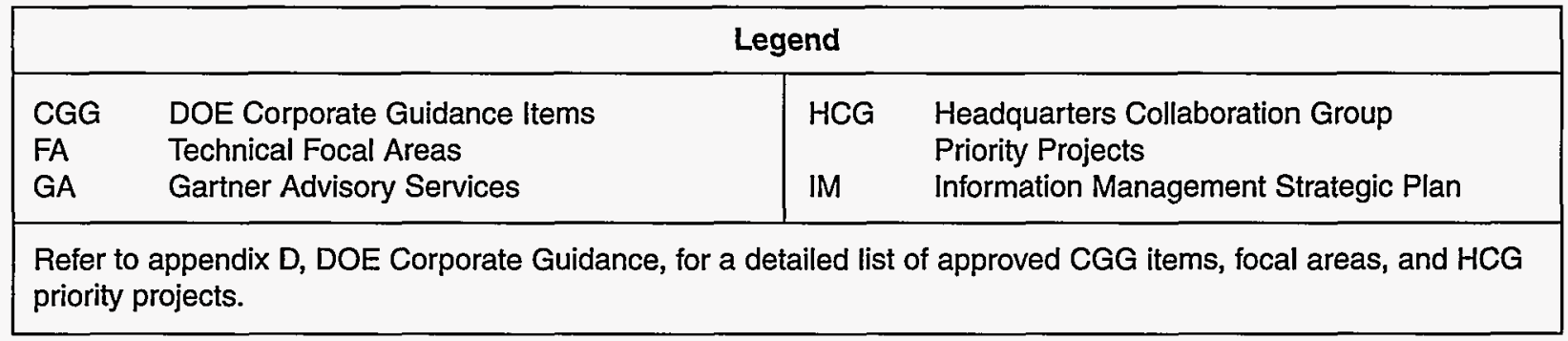

\begin{tabular}{|c|c|c|c|c|}
\hline \multicolumn{5}{|c|}{ Corporate Applications Inventory } \\
\hline Application & Description & Capabilities & Reference & Technology \\
\hline $\begin{array}{l}\text { Business } \\
\text { Management } \\
\text { Information } \\
\text { System } \\
\text { (BMIS)/ } \\
\text { Financial } \\
\text { Management } \\
\text { Information } \\
\text { System } \\
\text { (FMIS) }\end{array}$ & $\begin{array}{l}\text { Integrated corporate } \\
\text { system to integrate } \\
\text { planning, budgeting, } \\
\text { and accounting } \\
\text { processes. Utilize } \\
\text { COTS products, } \\
\text { replace existing } \\
\text { systems and use } \\
\text { financial data } \\
\text { warehouse. }\end{array}$ & $\begin{array}{l}\text { - Capture budget and } \\
\text { cost info } \\
\text { - Cross-cutting } \\
\text { reporting } \\
\text { - Share data across } \\
\text { systems/sites } \\
\text { - Performance } \\
\text { measurement }\end{array}$ & $\begin{array}{l}\text { FA 14, } 15 \\
\text { HCG } 3,7 \\
\text { IM \#4, } 6\end{array}$ & $\begin{array}{l}\text { - Network Computing } \\
\text { - LAN/WAN Telecom } \\
\text { - Data Dictionary } \\
\text { - Data Warehouse } \\
\text { - Modular Software }\end{array}$ \\
\hline $\begin{array}{l}\text { Energy } \\
\text { Information } \\
\text { Administration } \\
\text { (EIA) } \\
\text { Information }\end{array}$ & $\begin{array}{l}\text { System that } \\
\text { manages energy } \\
\text { data related to } \\
\text { production, } \\
\text { consumption, costs, } \\
\text { and forecasts. }\end{array}$ & $\begin{array}{l}\text { - Reports facts on } \\
\text { energy } \\
\text { consumption, fuel } \\
\text { costs, imports } \\
\text { - WEB access to } \\
\text { historical data } \\
\text { - Monthly and annual } \\
\text { forecasts }\end{array}$ & $\begin{array}{l}\text { CGG } 0020 \\
\text { CGG } 0021 \\
\text { CGG } 0236 \\
\text { CGG } 0239 \\
\text { IM \#2, } 6\end{array}$ & $\begin{array}{l}\text { - Internet Access } \\
\text { - LAN/WAN Telecom }\end{array}$ \\
\hline $\begin{array}{l}\text { Environment, } \\
\text { Safety \& } \\
\text { Health } \\
\text { (ES\&H) } \\
\text { Reporting } \\
\text { System }\end{array}$ & $\begin{array}{l}\text { Corporate system to } \\
\text { integrate safety } \\
\text { reporting systems } \\
\text { across enterprise. } \\
\text { Ensure data } \\
\text { compatibility, } \\
\text { interoperability, and } \\
\text { cross-cutting } \\
\text { information. }\end{array}$ & $\begin{array}{l}\text { - Report accidents } \\
\text { and injuries } \\
\text { - Report occurrences } \\
\text { - Monitor radiation } \\
\text { exposure } \\
\text { - Track non- } \\
\text { compliance }\end{array}$ & $\begin{array}{l}\text { CGG } 0003 \\
\text { CGG } 0020 \\
\text { CGG } 0021 \\
\text { CGG } 0236 \\
\text { CGG } 0239\end{array}$ & $\begin{array}{l}\text { - Internet Access } \\
\text { - Distributed } \\
\text { Application } \\
\text { Architectures } \\
\text { - LAN/WAN Telecom }\end{array}$ \\
\hline
\end{tabular}




\begin{tabular}{|ll|ll|}
\hline \multicolumn{3}{|c|}{ Legend } \\
\hline CGG & DOE Corporate Guidance Items & HCG & $\begin{array}{l}\text { Headquarters Collaboration Group } \\
\text { FA }\end{array}$ \\
GA & Technical Focal Areas & Gartner Advisory Services & Information Management Strategic Plan \\
\hline $\begin{array}{l}\text { Refer to appendix D, DOE Corporate Guidance, for a detailed list of approved CGG items, focal areas, and HCG } \\
\text { priority projects. }\end{array}$ \\
\hline
\end{tabular}

\begin{tabular}{|c|c|c|c|c|}
\hline \multicolumn{5}{|c|}{ Corporate Applications Inventory } \\
\hline Application & Description & Capabilities & Reference & Technology \\
\hline $\begin{array}{l}\text { Helpdesk and } \\
\text { Infrastructure } \\
\text { Management } \\
\text { (APPLIX) }\end{array}$ & $\begin{array}{l}\text { Call tracking and } \\
\text { resolution } \\
\text { component with } \\
\text { knowledgebase for } \\
\text { "how-to" information } \\
\text { about software } \\
\text { products such as } \\
\text { MS Office and } \\
\text { Windows 95. } \\
\text { Supports network } \\
\text { management and is } \\
\text { accessible by Web. }\end{array}$ & $\begin{array}{l}\text { - Track service calls } \\
\text { - Create expert } \\
\text { system solutions } \\
\text { - Customer service }\end{array}$ & $\begin{array}{l}\mathrm{HCG} 2,3 \\
8,9\end{array}$ & $\begin{array}{l}\text { - Internet Access } \\
\text { - LAN/WAN Telecom } \\
\text { - Modular Software }\end{array}$ \\
\hline $\begin{array}{l}\text { Nationwide } \\
\text { Locator } \\
\text { Information } \\
\text { (Call-Up) }\end{array}$ & $\begin{array}{l}\text { Centralized } \\
\text { repository of } \\
\text { telephone and } \\
\text { locator information } \\
\text { accessible through } \\
\text { the Web and } \\
\text { Windows-based } \\
\text { client/server } \\
\text { applications. }\end{array}$ & $\begin{array}{l}\text { Provides DOEwide } \\
\text { access to all federal } \\
\text { and contractor staff } \\
\text { - Online National } \\
\text { DOE Directory }\end{array}$ & $\begin{array}{l}\text { CGG } 0020 \\
\text { CGG } 0021 \\
\text { CGG } 0236 \\
\text { CGG } 0239 \\
\text { IM \#2, } 6\end{array}$ & $\begin{array}{l}\text { - Data Dictionary } \\
\text { - Data Warehouse } \\
\text { - Internet Access }\end{array}$ \\
\hline
\end{tabular}




\begin{tabular}{|c|c|c|c|}
\hline \multicolumn{4}{|c|}{ Legend } \\
\hline $\begin{array}{l}\text { CGG } \\
\text { FA } \\
\text { GA }\end{array}$ & $\begin{array}{l}\text { DOE Corporate Guidance Items } \\
\text { Technical Focal Areas } \\
\text { Gartner Advisory Services }\end{array}$ & $\begin{array}{l}\text { HCG } \\
\text { IM }\end{array}$ & $\begin{array}{l}\text { Headquarters Collaboration Group } \\
\text { Priority Projects } \\
\text { Information Management Strategic Plan }\end{array}$ \\
\hline $\mathrm{R}$ & DF Cornorate & & approved CGG items, focal are \\
\hline
\end{tabular}

\begin{tabular}{|c|c|c|c|c|}
\hline \multicolumn{5}{|c|}{ Corporate Applications Inventory } \\
\hline Application & Description & Capabilities & Reference & Technology \\
\hline $\begin{array}{l}\text { Procurement } \\
\text { and } \\
\text { Assistance } \\
\text { Data System } \\
\text { (PADS) }\end{array}$ & $\begin{array}{l}\text { Provides automated } \\
\text { support for } \\
\text { processing } \\
\text { procurement } \\
\text { requests and } \\
\text { awards and } \\
\text { generating reports. } \\
\text { Operates under } \\
\text { SYSTEM } 2000 \\
\text { Database/CLIST on } \\
\text { the mainframe. } \\
\text { Feeds other } \\
\text { systems through } \\
\text { data extracts } \\
\text { transferred to other } \\
\text { hosts via } \\
\text { telecommunications } \\
\text { or manually. }\end{array}$ & $\begin{array}{l}\text { - Process } \\
\text { procurement } \\
\text { requests and } \\
\text { awards } \\
\text { - Download extracts } \\
\text { for manual } \\
\text { manipulation } \\
\text { - Query database } \\
\text { online or via } \\
\text { programmed } \\
\text { reports } \\
\text { - Transmit data } \\
\text { extracts to server } \\
\text { via File Transfer } \\
\text { Protocol (FTP) } \\
\text { - Interface with other } \\
\text { DOE systems (e.g., } \\
\text { Departmental } \\
\text { Integrated } \\
\text { Standardized Core } \\
\text { Accounting System } \\
\text { (DISCAS) }\end{array}$ & $\begin{array}{l}\text { CGG } 0009 \\
\text { CGG } 0030 \\
\text { CGG } 0031 \\
\text { CGG } 0228 \\
\text { CGG } 0235 \\
\text { CGG } 0236 \\
\text { HCG } 10 \\
\text { FA\#6 }\end{array}$ & $\begin{array}{l}\text { - Desktop Platform } \\
\text { - LAN/ WAN } \\
\text { Telecom } \\
\text { - Electronic } \\
\text { Document } \\
\text { Interchange }\end{array}$ \\
\hline $\begin{array}{l}\text { Career } \\
\text { Counselor } \\
\text { System }\end{array}$ & $\begin{array}{l}\text { Provides career } \\
\text { development, career } \\
\text { transitioning, and } \\
\text { workforce } \\
\text { reengineering } \\
\text { services. OPM- } \\
\text { sponsored } \\
\text { application provided } \\
\text { to major Federal } \\
\text { Agencies. }\end{array}$ & $\begin{array}{l}\text { - Skill assessment } \\
\text { - View occupational } \\
\text { profiles } \\
\text { - Access training } \\
\text { courses } \\
\text { - Create a career } \\
\text { development plan } \\
\text { - Locate current job } \\
\text { vacancies }\end{array}$ & $\begin{array}{l}\text { CGG } 0005 \\
I M \# 5,6\end{array}$ & $\begin{array}{l}\text { - Network } \\
\text { Management } \\
\text { - Modular Software }\end{array}$ \\
\hline
\end{tabular}




\begin{tabular}{|ll|ll|}
\hline \multicolumn{3}{|c|}{ Legend } \\
\hline CGG & DOE Corporate Guidance Items & HCG & $\begin{array}{l}\text { Headquarters Collaboration Group } \\
\text { Priority Projects }\end{array}$ \\
FA & Technical Focal Areas & Information Management Strategic Plan \\
\hline GA & Gartner Advisory Services & IM & Refer to appendix D, DOE Corporate Guidance, for a detailed list of approved CGG items, focal areas, and HCG \\
priority projects.
\end{tabular}

\begin{tabular}{|c|c|c|c|c|}
\hline \multicolumn{5}{|c|}{ Corporate Applications Inventory } \\
\hline Application & Description & Capabilities & Reference & Technology \\
\hline $\begin{array}{l}\text { Solomon } \\
\text { Performance } \\
\text { Measurement/ } \\
\text { Evaluation } \\
\text { Information } \\
\text { System }\end{array}$ & $\begin{array}{l}\text { Web-based database } \\
\text { that manages the } \\
\text { status of measures } \\
\text { in meeting } \\
\text { Performance } \\
\text { Agreement between } \\
\text { the Secretary of } \\
\text { Energy and the } \\
\text { President. }\end{array}$ & $\begin{array}{l}\text { - Provides text of } \\
\text { commitments } \\
\text { - Records successes } \\
\text { - Manages points-of- } \\
\text { contact information } \\
\text { - Provides status on } \\
\text { each commitment } \\
\text { - Web access }\end{array}$ & $\begin{array}{l}\text { CGG } 0002 \\
\text { CGG } 0020 \\
\text { CGG } 0021 \\
\text { CGG } 0236 \\
\text { CGG } 0239 \\
\text { IM \#2, } 6\end{array}$ & $\begin{array}{l}\text { - Network } \\
\text { Management } \\
\text { - LAN/WAN Telecom } \\
\text { - Internet Access }\end{array}$ \\
\hline $\begin{array}{l}\text { Systems } \\
\text { Catalog (new) }\end{array}$ & $\begin{array}{l}\text { Systems aligned } \\
\text { with DOE } \\
\text { architectures are } \\
\text { maintained in this } \\
\text { application. May } \\
\text { include distributed, } \\
\text { client-server } \\
\text { systems based on } \\
\text { SQL database and } \\
\text { other corporate } \\
\text { standards. }\end{array}$ & $\begin{array}{l}\text { - Inventory } \\
\text { - Configuration } \\
\text { Management }\end{array}$ & $\begin{array}{l}\text { CGG } 0201 \\
\text { CGG } 0238 \\
\text { FA 14, } 15 \\
\text { IM \#3, } 6\end{array}$ & $\begin{array}{l}\text { - Data Dictionary } \\
\text { - Data } \\
\text { - IA Process } \\
\text { - Warehouse/Marts }\end{array}$ \\
\hline $\begin{array}{l}\text { Travel } \\
\text { Manager } \\
\text { System }\end{array}$ & $\begin{array}{l}\text { Governmentwide } \\
\text { system that } \\
\text { automates travel } \\
\text { regulations, travel } \\
\text { authorization, and } \\
\text { voucher preparation } \\
\text { and processing. }\end{array}$ & $\begin{array}{l}\text { - Provides } \\
\text { regulations } \\
\text { - Monthly updates of } \\
\text { travel rates } \\
\text { - Processes travel } \\
\text { paperwork }\end{array}$ & $\begin{array}{l}\text { CGG } 0006 \\
\text { CGG } 0007 \\
\text { CGG } 0210 \\
\text { HCG } 7 \\
\text { IM \#4,6 }\end{array}$ & $\begin{array}{l}\text { - Distributed } \\
\text { Application } \\
\text { Architecture } \\
\text { - Network } \\
\text { Management }\end{array}$ \\
\hline
\end{tabular}




\section{Appendix C}

\section{Prototype Technology List}




\section{Legend}

\begin{tabular}{ll|ll|l}
\hline CGG & DOE Corporate Guidance Items & GA & $\begin{array}{l}\text { Gartner Advisory Services } \\
\text { FA }\end{array}$ & Technical Focal Areas
\end{tabular}

Refer to appendix B, DOE Corporate Guidance, for a detailed list of approved CGG items, focal areas, and HCG priority projects.

\begin{tabular}{|c|c|c|c|c|c|c|}
\hline \multicolumn{7}{|c|}{ Prototype Technology List } \\
\hline Technology & Description & DOE Reference & Notes & $1998-1999$ & $2000-2003$ & 2004 and Beyond \\
\hline $\begin{array}{l}\text { Information } \\
\text { Architecture } \\
\text { Process }\end{array}$ & $\begin{array}{l}\text { Implementation of architecting } \\
\text { processes to define business, } \\
\text { data, information, applications, } \\
\text { and technology requirements to } \\
\text { support an orderly } \\
\text { migration/implementation plan. }\end{array}$ & $\begin{array}{l}\text { CGG } 0210 \\
\text { CGG } 0228 \\
\text { CGG } 0301 \\
\text { FA \#1, } 2,3,4,5,6,7 \text {, } \\
8,9,10,11,12,13 \\
14,15,16,17 \\
\text { IM Goals } 1,2,3,6\end{array}$ & $\begin{array}{l}\text { Successful completion of } \\
\text { process in Energy } \\
\text { Research model for } \\
\text { DOEwide implementation. } \\
\# 1 \text { ClO Challenge per } \\
11 / 97 \text { survey. }\end{array}$ & $\begin{array}{l}\text { HQ and other } \\
\text { elements initiates EAP. } \\
\text { Business participation } \\
\text { promoted by head of } \\
\text { organization. }\end{array}$ & $\begin{array}{l}\text { Architecture process } \\
\text { adopted by program } \\
\text { areas and majority of } \\
\text { field sites. Benefits } \\
\text { visible and } \\
\text { collaborative efforts } \\
\text { proliferate. }\end{array}$ & $\begin{array}{l}\text { DOE recognized as } \\
\text { leader in federal } \\
\text { sector in supporting } \\
\text { business lines } \\
\text { through technology } \\
\text { while managing } \\
\text { costs over time. }\end{array}$ \\
\hline $\begin{array}{l}\text { Network } \\
\text { Management }\end{array}$ & $\begin{array}{l}\text { Centralized management of } \\
\text { distributed networks using } \\
\text { available tools to monitor, plan, } \\
\text { and troubleshoot diverse } \\
\text { elements. }\end{array}$ & $\begin{array}{l}\text { CGG } 0020 \\
\text { CGG } 0021 \\
\text { CGG } 0030 \\
\text { CGG } 0233 \\
\text { CGG } 0235 \\
\text { CGG } 0236 \\
\text { CGG } 0239 \\
\text { FA \# } 3,5,6,9,11,13 \text {, } \\
15,16 \\
\text { HCG } \# 1,2,6,8\end{array}$ & $\begin{array}{l}\text { Network nodes managed at } \\
\text { the enterprisewide level. }\end{array}$ & $\begin{array}{l}\text { DOE Business } \\
\text { Network } \\
\text { ESNET } \\
\text { DP Intranet } \\
\text { HQ CCB }\end{array}$ & $\begin{array}{l}\text { HR initiatives result in } \\
\text { standardized network } \\
\text { management tools } \\
\text { procured and } \\
\text { implemented across } \\
\text { the organization. }\end{array}$ & $\begin{array}{l}\text { Architectured } \\
\text { environment } \\
\text { provides central } \\
\text { authority and } \\
\text { guidance for } \\
\text { distributed } \\
\text { management of } \\
\text { networks. }\end{array}$ \\
\hline Data Dictionary & $\begin{array}{l}\text { Standard definition of data } \\
\text { entities to allow } \\
\text { synchronization/consolidation } \\
\text { across databases. Essential } \\
\text { component of architected } \\
\text { environment. }\end{array}$ & $\begin{array}{l}\text { CGG } 0007 \\
\text { CGG } 0008 \\
\text { CGG } 0031 \\
\text { CGG } 0228 \\
\text { CGG } 0232 \\
\text { CGG } 0301 \\
\text { FA\# } 1,5,7,13,14,15\end{array}$ & $\begin{array}{l}\text { Common definitions for } \\
\text { data elements allow } \\
\text { sharing of data across } \\
\text { enterprise. }\end{array}$ & $\begin{array}{l}\text { Financial and } \mathrm{HR} \\
\text { data dictionary }\end{array}$ & $\begin{array}{l}\text { Establishment of } \\
\text { corporate data } \\
\text { dictionary }\end{array}$ & $\begin{array}{l}\text { Most corporate } \\
\text { systems now } \\
\text { dependent on data } \\
\text { dictionary. } \\
\text { International data } \\
\text { standards cover most } \\
\text { DOE data elements. }\end{array}$ \\
\hline
\end{tabular}




\begin{tabular}{|c|c|c|c|c|}
\hline $\begin{array}{l}\text { CGG } \\
\text { FA }\end{array}$ & $\begin{array}{l}\text { DOE Corporate Guidance Items } \\
\text { Technical Focal Areas }\end{array}$ & $\begin{array}{l}\text { GA } \\
\text { IM }\end{array}$ & $\begin{array}{l}\text { Gartner Advisory Services } \\
\text { Information Management Strategic Plan }\end{array}$ & Headquarters Collaboration Group Priority Projects \\
\hline
\end{tabular}

\begin{tabular}{|c|c|c|c|c|c|c|}
\hline \multicolumn{7}{|c|}{ Prototype Technology List } \\
\hline Technology & Description & DOE Reference & Notes & 1998-1999 & $2000-2003$ & 2004 and Beyond \\
\hline Security & $\begin{array}{l}\text { Policies and technical solutions to } \\
\text { protect corporate data. Tools } \\
\text { may include: firewalls, user } \\
\text { identification \& authentication, } \\
\text { virus protection, and encryption. }\end{array}$ & $\begin{array}{l}\text { CGG } 0026 \\
\text { CGG } 0231 \\
\text { CGG } 0234 \\
\text { CGG } 0236 \\
\text { CGG 0239 } \\
\text { FA \#3, 4, 5, 13, } 15 \\
\text { HCG \#4,5 }\end{array}$ & Critical priority for DOE & $\begin{array}{l}\text { CIAC in Place. } \\
\text { Guidelines /Standards } \\
\text { for digital signature } \\
\text { approved for DOE. } \\
\text { Began implementing } \\
\text { PKI. }\end{array}$ & $\begin{array}{l}\text { PKI implementation } \\
\text { complete and } \\
\text { standardized firewalls } \\
\text { Overall DOEwide } \\
\text { security policy. }\end{array}$ & $\begin{array}{l}\text { DOE continues its } \\
\text { commitment to } \\
\text { technical security, } \\
\text { one of its original } \\
\text { principles. }\end{array}$ \\
\hline $\begin{array}{l}\text { Expanded } \\
\text { E-mail/Noice } \\
\text { Messaging }\end{array}$ & $\begin{array}{l}\text { Centralized directory services. } \\
\text { Central mailbox for voice mail, } \\
\text { e-mail, faxes that can be } \\
\text { accessed remotely via phone, } \\
\text { fax, or Web browser. }\end{array}$ & $\begin{array}{l}\text { CGG } 0022 \\
\text { CGG } 0228 \\
\text { CGG } 0233 \\
\text { CGG } 0235 \\
\text { FA \#2, 11, 15, } 16 \\
\text { HCG \#1, } 2 \\
\text { IM Goal } 5\end{array}$ & $\begin{array}{l}\text { Directory services critical } \\
\text { precedent }\end{array}$ & $\begin{array}{l}\text { Novell Directory } \\
\text { Services-fragmented } \\
\text { directory services in } \\
\mathrm{HQ}\end{array}$ & $\begin{array}{l}\text { Coordinated planning } \\
\text { across DOE results in } \\
\text { moves to standardized } \\
\text { platiorm with } \\
\text { centralized directory } \\
\text { services. }\end{array}$ & $\begin{array}{l}\text { E-mail and voice } \\
\text { mail integrated in } \\
\text { applications is norm } \\
\text { across DOE. }\end{array}$ \\
\hline $\begin{array}{l}\text { Internet } \\
\text { Access/Support }\end{array}$ & $\begin{array}{l}\text { World Wide Web via TCP/IP } \\
\text { protocols with security, content } \\
\text { controls, and management tools } \\
\text { in place. }\end{array}$ & $\begin{array}{l}\text { CGG } 0020 \\
\text { CGG } 0021 \\
\text { CGG } 0024 \\
\text { CGG } 0235 \\
\text { CGG } 0236 \\
\text { CGG } 0239 \\
\text { FA \#3, 5, 9, 10, 11, } 13 \\
\text { IM Goal } 5 \\
\text { HCG \#5, } 6\end{array}$ & $\begin{array}{l}\text { Security critical component } \\
\text { for DOE }\end{array}$ & $\begin{array}{l}\text { TCP/IP for all sites by } \\
\text { FY98 }\end{array}$ & $\begin{array}{l}\text { Web use integrated } \\
\text { into business } \\
\text { processes. }\end{array}$ & $\begin{array}{l}\text { Corporate systems } \\
\text { Web-enabled with } \\
\text { secure user } \\
\text { authentication. }\end{array}$ \\
\hline
\end{tabular}




\begin{tabular}{|c|c|c|c|c|c|}
\hline \multicolumn{6}{|c|}{ Legend } \\
\hline $\begin{array}{l}\text { CGG } \\
\text { FA }\end{array}$ & $\begin{array}{l}\text { DOE Corporate Guidance Items } \\
\text { Technical Focal Areas }\end{array}$ & $\begin{array}{l}\text { GA } \\
\mathrm{IM}\end{array}$ & $\begin{array}{l}\text { Gartner Advisory Services } \\
\text { Information Management Strategic Plan }\end{array}$ & HCG & Headquarters Collaboration Group Priority Projects \\
\hline
\end{tabular}

\begin{tabular}{|c|c|c|c|c|c|c|}
\hline \multicolumn{7}{|c|}{ Prototype Technology List } \\
\hline Technology & Description & DOE Reference & Notes & 1998-1999 & $2000-2003$ & 2004 and Beyond \\
\hline $\begin{array}{l}\text { Electronic } \\
\text { Document } \\
\text { Interchange/ } \\
\text { Electronic } \\
\text { Commerce }\end{array}$ & $\begin{array}{l}\text { Common documentinformation } \\
\text { interchange standards to ensure } \\
\text { that all recipients can view } \\
\text { documents in the original } \\
\text { formats. } \\
\text { Tools like smart forms and fax on } \\
\text { demand enhance Government's } \\
\text { ability to deliver customer } \\
\text { services to the public. }\end{array}$ & $\begin{array}{l}\text { CGG } 0009 \\
\text { CGG } 0010 \\
\text { CGG } 0022 \\
\text { CGG } 0228 \\
\text { CGG } 0235 \\
\text { CGG } 0236 \\
\text { FA \#2, 3, 5, 8, 9, 10, } \\
11,13,15 \\
\text { IM Goal } 3,5\end{array}$ & $\begin{array}{l}\text { Component of electronic } \\
\text { commerce }\end{array}$ & $\begin{array}{l}\text { Pilot project involves } \\
\text { small purchases }\end{array}$ & $\begin{array}{l}\text { Used for all DOE } \\
\text { federal purchases }\end{array}$ & $\begin{array}{l}\text { Expanded to grants } \\
\text { and awards process }\end{array}$ \\
\hline Desktop Platform & $\begin{array}{l}\text { Standard desktop configuration } \\
\text { including basic hardware, } \\
\text { operating system, } \\
\text { communications, and applications } \\
\text { suites(s). }\end{array}$ & $\begin{array}{l}\text { CGG } 0020 \\
\text { CGG } 0228 \\
\text { CGG } 0234 \\
\text { CGG } 0301 \\
\text { FA\# } 5,8,9,10,11 \text {, } \\
12,15 \\
\text { HCG } \# 2,9\end{array}$ & $\begin{array}{l}\text { Primary vehicle for user to } \\
\text { perform information } \\
\text { technology functions. }\end{array}$ & $\begin{array}{l}\text { Migration to Windows } \\
\text { 95/NT }\end{array}$ & $\begin{array}{l}\text { Applications support } \\
\text { leaner clients }\end{array}$ & $\begin{array}{l}\text { Cost issues drive } \\
\text { the trend toward a } \\
\text { more diverse } \\
\text { desktop platform, } \\
\text { including centrally- } \\
\text { managed, server- } \\
\text { centric desktops } \\
\text { with limited } \\
\text { functionality for } \\
\text { select users (GA). }\end{array}$ \\
\hline LAN/WAN Telecom & $\begin{array}{l}\text { Infrastructure to provide reliable, } \\
\text { cost-effective data transmission } \\
\text { services for local and remote } \\
\text { connectivity. Tools include multi- } \\
\text { protocol switches, fiber optic } \\
\text { cables, high bandwidth } \\
\text { capacities, and robust servers. }\end{array}$ & $\begin{array}{l}\text { CGG 0020 } \\
\text { CGG 0021 } \\
\text { CGG 0022 } \\
\text { CGG 0024 } \\
\text { CGG 0030 } \\
\text { CGG } 0235 \\
\text { CGG } 0236 \\
\text { CGG } 0301 \\
\text { FA \#2, 3, 4, 5, 6, 7, 8, } \\
9,10,11,13 \\
\text { HCG \#1,5,6 }\end{array}$ & $\begin{array}{l}\text { Architectural process and } \\
\text { managed DOE network } \\
\text { essential ingredients }\end{array}$ & $\begin{array}{l}\text { DOE elements } \\
\text { collaborate to upgrade } \\
\text { technical infrastructure } \\
\text { to remove bottlenecks } \\
\text { in network traffic } \\
\text { demands. }\end{array}$ & $\begin{array}{l}\text { Bandwith increases to } \\
\text { accommodate video }\end{array}$ & $\begin{array}{l}\text { Traffic increases at } \\
\text { DOE supported by } \\
\text { standardized } \\
\text { services and ever- } \\
\text { expanding demands } \\
\text { met. }\end{array}$ \\
\hline
\end{tabular}




\begin{tabular}{|ll|ll|l|}
\hline \multicolumn{4}{|c|}{ Legend } \\
\hline $\begin{array}{l}\text { CGG } \\
\text { FA }\end{array} \begin{array}{l}\text { DOE Corporate Guidance Items } \\
\text { Technical Focal Areas }\end{array}$ & $\begin{array}{l}\text { GA } \\
\text { IM }\end{array}$ & $\begin{array}{l}\text { Gartner Advisory Services } \\
\text { Information Management Strategic Plan }\end{array}$ & HCG Headquarters Collaboration Group Priority Projects \\
\hline Refer to appendix B, DOE Corporate Guidance, for a detalled list of approved CGG items, focal areas, and HCG priority projects. \\
\hline
\end{tabular}

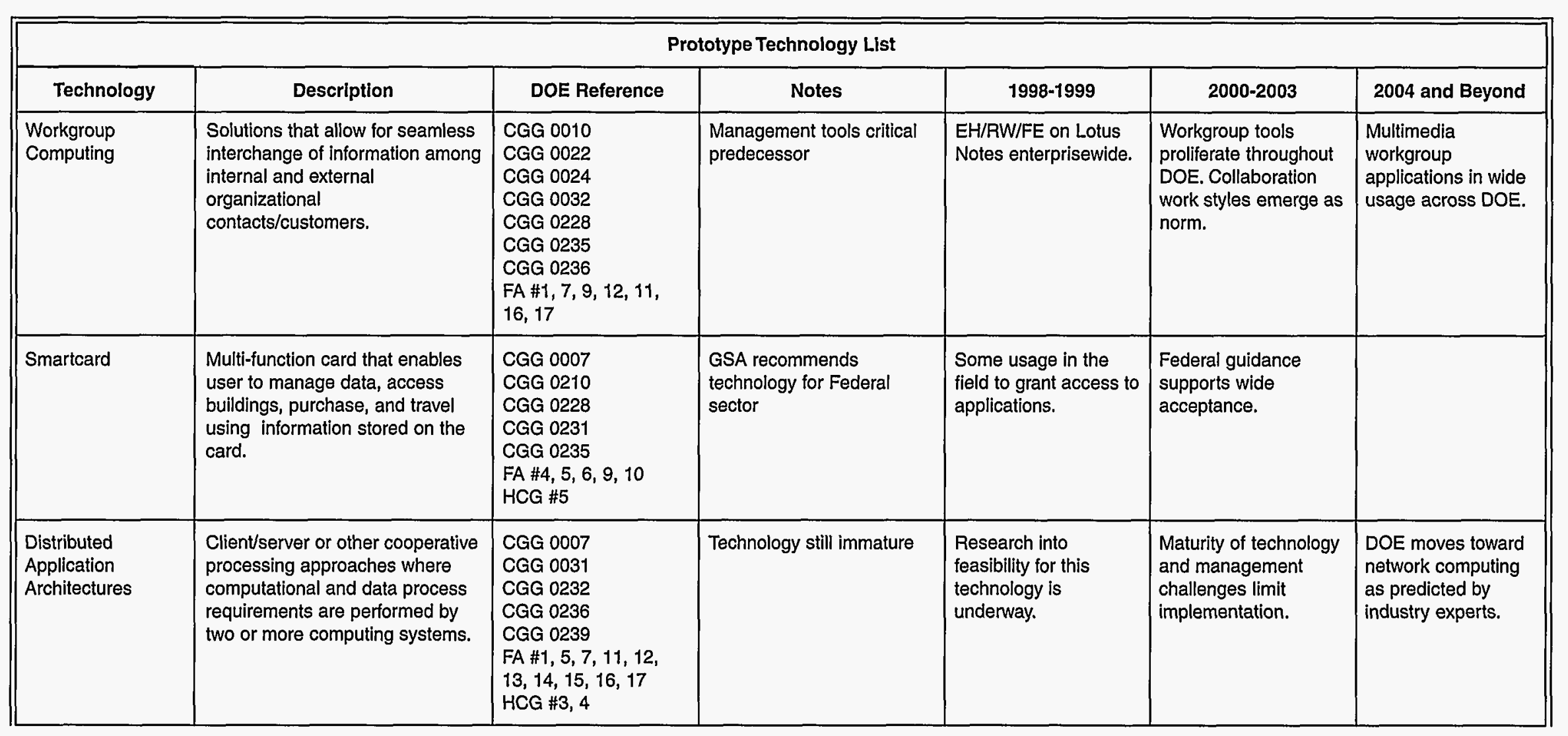

\section{Volume IV, Vision}




\begin{tabular}{|ll|l|l|}
\hline \multicolumn{3}{|c|}{ Legend } \\
\hline $\begin{array}{l}\text { CGG } \\
\text { FA }\end{array} \quad \begin{array}{l}\text { DOE Corporate Guidance ltems } \\
\text { Technical Focal Areas }\end{array}$ & \begin{tabular}{l} 
GA $\quad \begin{array}{l}\text { Gartner Advisory Services } \\
\text { Information Management Strategic Plan }\end{array}$ \\
\hline
\end{tabular} Refer to appendix B, DOE Corporate Guidance, for a detailed list of approved CGG items, focal areas, and HCG priority projects. \\
\hline
\end{tabular}

\begin{tabular}{|c|c|c|c|c|c|c|}
\hline \multicolumn{7}{|c|}{ Prototype Technology List } \\
\hline Technology & Description & DOE Reference & Notes & 1998-1999 & $2000-2003$ & 2004 and Beyond \\
\hline $\begin{array}{l}\text { Data } \\
\text { Warehouse(s) }\end{array}$ & $\begin{array}{l}\text { Repository of corporate data } \\
\text { extracted from existing } \\
\text { transaction systems that supports } \\
\text { both structured and ad hoc } \\
\text { access. Independent from } \\
\text { production systems. Essential } \\
\text { component of architected } \\
\text { environment. }\end{array}$ & $\begin{array}{l}\text { CGG } 0007 \\
\text { CGG } 0031 \\
\text { CGG } 0232 \\
\text { CGG 0236 } \\
\text { CGG 0301 } \\
\text { FA \#1, } 5,7,13,14, \\
15 \\
\text { HCG \#4 } \\
\text { IM Goal \#4 }\end{array}$ & $\begin{array}{l}\text { Essential element in } \\
\text { architected environment to } \\
\text { share data environments. }\end{array}$ & $\begin{array}{l}H R \text { and financial data } \\
\text { warehouses initial } \\
\text { efforts at } H Q\end{array}$ & $\begin{array}{l}\text { DOE adopts model for } \\
\text { all development } \\
\text { efforts. Select } \\
\text { corporate systems } \\
\text { (financial, document } \\
\text { management) } \\
\text { populate data } \\
\text { warehouses. }\end{array}$ & $\begin{array}{l}\text { Sharing data } \\
\text { becomes the norm } \\
\text { for DOE business } \\
\text { systems. Human } \\
\text { resources system } \\
\text { models the benefits } \\
\text { gained. }\end{array}$ \\
\hline $\begin{array}{l}\text { Video } \\
\text { Conferencing }\end{array}$ & $\begin{array}{l}\text { Ability to deliver multipoint video } \\
\text { teleconferencing at the desktop } \\
\text { integrated with interactive } \\
\text { workgroup applications and } \\
\text { network transmission of voice, } \\
\text { video, and sound. }\end{array}$ & $\begin{array}{l}\text { CGG } 0032 \\
\text { CGG } 0228 \\
\text { CGG } 0235 \\
\text { CGG } 0236 \\
\text { FA \#7, } 8,9,10,11, \\
12,13,16,17 \\
\text { HCG \#9 }\end{array}$ & $\begin{array}{l}\text { Network infrastructure limits } \\
\text { DOE deployment. }\end{array}$ & $\begin{array}{l}\text { Pilot projects in select } \\
\text { program areas }\end{array}$ & $\begin{array}{l}\text { Continues to expand } \\
\text { as network upgrades } \\
\text { support bandwidth } \\
\text { demands. }\end{array}$ & $\begin{array}{l}\text { Integrated } \\
\text { coillaborative } \\
\text { technologies } \\
\text { converge to support } \\
\text { "virtual meetings" } \\
\text { with interactive } \\
\text { electronic } \\
\text { participation (GA). }\end{array}$ \\
\hline Whiteboarding & $\begin{array}{l}\text { Collaboration software allows } \\
\text { participants to log on, view } \\
\text { documents and images, and } \\
\text { edit/annotate documents. Part of } \\
\text { workgroup and multimedia } \\
\text { toolset. }\end{array}$ & $\begin{array}{l}\text { CGG } 0032 \\
\text { CGG } 0235 \\
\text { CGG } 0236 \\
\text { FA \#7, 8,11, 12, 13, } \\
16,17 \\
\text { HCG \#9 } \\
\text { IM Goal 5,6 }\end{array}$ & $\begin{array}{l}\text { Scattered implementation } \\
\text { but not widespread. }\end{array}$ & ER Technology Project & $\begin{array}{l}\text { DOE promotes the } \\
\text { workgroup team skills } \\
\text { used in this } \\
\text { technology, along with } \\
\text { other collaborative } \\
\text { tools. }\end{array}$ & $\begin{array}{l}\text { Whiteboarding } \\
\text { thoroughly } \\
\text { integrated into } \\
\text { groupware } \\
\text { processes. }\end{array}$ \\
\hline
\end{tabular}


Legend

\begin{tabular}{|l|l|l|l|}
\hline \multicolumn{4}{|c|}{ Legend } \\
\hline $\begin{array}{l}\text { CGG } \\
\text { FA DOE Corporate Guidance Items }\end{array} \quad$ Technical Focal Areas & IM $\quad \begin{array}{l}\text { Gartner Advisory Services } \\
\text { Information Management Strategic Plan }\end{array}$ & HCG & Headquarters Collaboration Group Priority Projects \\
\hline \multicolumn{2}{|l|}{ Refer to appendix B, DOE Corporate Guidance, for a detailed list of approved CGG items, focal areas, and HCG priority projects. } \\
\hline
\end{tabular}

\begin{tabular}{|c|c|c|c|c|c|c|}
\hline \multicolumn{7}{|c|}{ Prototype Technology List } \\
\hline Technology & Description & DOE Reference & Notes & $1998-1999$ & $2000-2003$ & 2004 and Beyond \\
\hline Push Technology & $\begin{array}{l}\text { Automatically delivers } \\
\text { information, data, and software } \\
\text { applications from one point to } \\
\text { another "just in time." }\end{array}$ & $\begin{array}{l}\text { CGG } 0022 \\
\text { FA \#7, 8, 9, 10, } 16 \\
\text { HCG \#4 }\end{array}$ & $\begin{array}{l}\text { Industry predicts } \\
\text { convergence of agents with } \\
\text { push technology to deliver } \\
\text { "just in time" knowledge to } \\
\text { the desktop. (GA) }\end{array}$ & $\begin{array}{l}\text { E-mail alerts simple } \\
\text { agent available. }\end{array}$ & $\begin{array}{l}\text { Collaborate workstyle } \\
\text { drives automatic } \\
\text { notification. }\end{array}$ & $\begin{array}{l}\text { Architectures drive } \\
\text { emphasis on rule- } \\
\text { based applications } \\
\text { used by this } \\
\text { technology. }\end{array}$ \\
\hline $\begin{array}{l}\text { Network } \\
\text { Computing }\end{array}$ & $\begin{array}{l}\text { Client/server application } \\
\text { architecture with dynamic } \\
\text { application deployment, } \\
\text { execution, and management. }\end{array}$ & $\begin{array}{l}\text { CGG } 0030 \\
\text { CGG } 0228 \\
\text { CGG } 0235 \\
\text { CGG } 0236 \\
\text { FA \#1, 3, 5, 9, 11, 12, } \\
13 \\
\text { HCG \#1, 4, } 6\end{array}$ & $\begin{array}{l}\text { Topic of current } \\
\text { marketplace confusion } \\
\text { regarding definition and } \\
\text { roles. (GA) }\end{array}$ & $\begin{array}{l}\text { Technology immature } \\
\text { for DOE. }\end{array}$ & $\begin{array}{l}\text { Research into evolving } \\
\text { technologies }\end{array}$ & $\begin{array}{l}\text { Forecast for } \\
\text { migration to lower- } \\
\text { cost network } \\
\text { computers for } \\
\text { limited function } \\
\text { environments (GA). }\end{array}$ \\
\hline $\begin{array}{l}\text { Intelligent Software } \\
\text { Agents }\end{array}$ & $\begin{array}{l}\text { Proactive autonomous programs } \\
\text { that act on specific situation to } \\
\text { supply user alerts, recommended } \\
\text { actions, automated decisions. } \\
\text { Intelligent agents go beyond } \\
\text { keyword searches with } \\
\text { collaborative filtering and natural } \\
\text { language processing. }\end{array}$ & $\begin{array}{l}\text { CGG } 0228 \\
\text { CGG } 0235 \\
\text { FA \#8, 9, 10,17 } \\
\text { HCG \#4 }\end{array}$ & $\begin{array}{l}\text { Presentation services that } \\
\text { will be key components in } \\
\text { productive decisions } \\
\text { support systems. }\end{array}$ & $\begin{array}{l}\text { Scheduled routines to } \\
\text { perform searches/ } \\
\text { maintenance in place. }\end{array}$ & $\begin{array}{l}\text { Maturity of processes } \\
\text { expands use of } \\
\text { intelligence agents. } \\
\text { Example: Automated } \\
\text { responses to } \\
\text { correspondence. }\end{array}$ & $\begin{array}{l}\text { Integrated with push } \\
\text { technology to deliver } \\
\text { range of services } \\
\text { automatically. }\end{array}$ \\
\hline $\begin{array}{l}\text { Wireless } \\
\text { Datacomm }\end{array}$ & $\begin{array}{l}\text { Uses radio spectrum rather than } \\
\text { physical medium for data } \\
\text { transmission with mobility as key } \\
\text { benefit. }\end{array}$ & $\begin{array}{l}\text { CGG } 0029 \\
\text { CGG } 0212 \\
\text { CGG } 0228 \\
\text { CGG } 0235 \\
\text { FA \#4, 5, 7, 8, 9, } 10 \\
\text { HCG \#5 }\end{array}$ & $\begin{array}{l}\text { Mobility requirements will } \\
\text { drive this technology. }\end{array}$ & $\begin{array}{l}\text { Interoperability and } \\
\text { security requirements } \\
\text { identified by DOEwide } \\
\text { group. }\end{array}$ & $\begin{array}{l}\text { Widespread use for } \\
\text { remote commuting. }\end{array}$ & $\begin{array}{l}\text { Capabilities and cost } \\
\text { compares to "wired" } \\
\text { technologies (GA). }\end{array}$ \\
\hline
\end{tabular}




\begin{tabular}{|c|c|c|c|c|c|}
\hline \multicolumn{6}{|c|}{ Legend } \\
\hline $\begin{array}{l}\text { CGG } \\
\text { FA }\end{array}$ & $\begin{array}{l}\text { DOE Corporate Guidance Items } \\
\text { Technical Focal Areas }\end{array}$ & $\begin{array}{l}\text { GA } \\
\text { IM }\end{array}$ & $\begin{array}{l}\text { Gartner Advisory Services } \\
\text { Information Management Strategic Plan }\end{array}$ & HCG & Headquarters Collaboration Group Priority Projects \\
\hline
\end{tabular}

\begin{tabular}{|c|c|c|c|c|c|c|}
\hline \multicolumn{7}{|c|}{ Prototype Technology List } \\
\hline Technology & Description & DOE Reference & Notes & 1998-1999 & $2000-2003$ & 2004 and Beyond \\
\hline $\begin{array}{l}\text { Modular } \\
\text { Software/Object } \\
\text { Oriented } \\
\text { Programming }\end{array}$ & $\begin{array}{l}\text { Application-building tools that } \\
\text { combine modular components. } \\
\text { Commercial off-the-shelf software } \\
\text { may also be used. }\end{array}$ & $\begin{array}{l}\text { CGG } 0007 \\
\text { CGG } 0031 \\
\text { CGG } 0214 \\
\text { CGG } 0232 \\
\text { CGG } 0301 \\
\text { FA \#1, 5, 7, 12, } 15 \\
\text { HCG \#4 }\end{array}$ & $\begin{array}{l}\text { DOE Software } \\
\text { Engineering Practices } \\
\text { support use of modular } \\
\text { components }\end{array}$ & $\begin{array}{l}\text { Several applications } \\
\text { adopt model }\end{array}$ & $\begin{array}{l}\text { Growing use of } \\
\text { modular software } \\
\text { across enterprise. }\end{array}$ & $\begin{array}{l}\text { Widespread } \\
\text { acceptance of } \\
\text { modular software. }\end{array}$ \\
\hline Data Mining & $\begin{array}{l}\text { Analysis of information to } \\
\text { discover meaningful correlations } \\
\text { and trends in large repositories. }\end{array}$ & $\begin{array}{l}\text { FA \#8, 9, 10, } 16 \\
\text { HCG \#4 }\end{array}$ & $\begin{array}{l}\text { Critical element of } \\
\text { Executive information } \\
\text { Systems that can transform } \\
\text { data overload to meaningful } \\
\text { knowledge. }\end{array}$ & $\begin{array}{l}\text { Search technologies in } \\
\text { some applications } \\
\text { (e.g., document } \\
\text { management) offer } \\
\text { robust full text search } \\
\text { tool. }\end{array}$ & $\begin{array}{l}\text { Tools for delivering } \\
\text { Information } \\
\text { Understanding } \\
\text { maturing rapidly (e.g., } \\
\text { natural language } \\
\text { understanding, speech } \\
\text { synthesis, machine } \\
\text { learning, image } \\
\text { understanding). }\end{array}$ & $\begin{array}{l}\text { Merges with } \\
\text { intelligent software } \\
\text { agents }\end{array}$ \\
\hline
\end{tabular}


Appendix D

\section{DOE Corporate Guidance}




\begin{tabular}{|c|c|c|c|}
\hline \multicolumn{4}{|c|}{ Approved Corporate IM Guidance Items } \\
\hline \multicolumn{2}{|c|}{ Corporate Management Information } & \multicolumn{2}{|r|}{ Infrastructure } \\
\hline CGG 0001 & Strategic Management System & CGG 0020 & TCP/IP for all sites by FY98 \\
\hline CGG 0002 & $\begin{array}{l}\text { Solomon Performance } \\
\text { Evaluation }\end{array}$ & CGG 0021 & Internet $M W W$ Access \\
\hline CGG 0003 & DOE ES \& H Reporting System & CGG 0022 & Electronic Mail \\
\hline CGG 0004 & $\begin{array}{l}\text { Corporate Human Resources } \\
\text { Information System (CHRIS) }\end{array}$ & CGG 0024 & DOE Electronic Commerce Gateway \\
\hline CGG 0005 & DOE Career Counselor System & CGG 0026 & $\begin{array}{l}\text { Computer Incident Advisory Capability } \\
\text { (CIAC) at DOE }\end{array}$ \\
\hline CGG 0006 & DOE Travel Manager System & CGG 0029 & Wireless Communication \\
\hline CGG 0007 & Year 2000 Date Standard & CGG 0030 & Network Operating System \\
\hline CGG 0008 & $\begin{array}{l}\text { Endorse Records Management } \\
\text { Standards "Roadmap 2000" }\end{array}$ & CGG 0031 & DOE Software Development Tools \\
\hline CGG 0009 & $\begin{array}{l}\text { Conversion to Electronic } \\
\text { Documents }\end{array}$ & CGG 0032 & Groupware Interoperability \\
\hline CGG 0010 & $\begin{array}{l}\text { Document Online Coordination } \\
\text { System (DOCS) }\end{array}$ & CGG 0050 & $\begin{array}{l}\text { Management and Accessibility of } \\
\text { Scientific and Technical Information }\end{array}$ \\
\hline CGG 0210 & $\begin{array}{l}\text { IM Products \& Services } \\
\text { Management Structure }\end{array}$ & CGG 0228 & Information Technology (IT) Standards \\
\hline CGG 0212 & $\begin{array}{l}\text { Defense Messaging System } \\
\text { (DMS) }\end{array}$ & CGG 0231 & $\begin{array}{l}\text { Public Key Infrastructure (PKI) } \\
\text { Certificate Policy }\end{array}$ \\
\hline CGG 0214 & $\begin{array}{l}\text { DOE Software Engineering } \\
\text { Practices }\end{array}$ & CGG 0232 & Year 2000 Guidance \\
\hline \multirow[t]{2}{*}{ CGG 0301} & \multirow{2}{*}{$\begin{array}{l}\text { Departmental Information } \\
\text { Architecture Guidance }\end{array}$} & CGG 0233 & Directory Services \\
\hline & & CGG 0234 & $\begin{array}{l}\text { Computer Virus Protection \& Incident } \\
\text { \& Information Advisories }\end{array}$ \\
\hline & & CGG 0235 & DOEwide Electronic Interoperability \\
\hline & & CGG 0236 & DOE Corporate Network \\
\hline & & CGG 0239 & $\begin{array}{l}\text { Access to Corporate Systems via } \\
\text { the Web }\end{array}$ \\
\hline
\end{tabular}




\begin{tabular}{|c|l|c|l||}
\hline \multicolumn{3}{|c|}{ Headquarters Collaboration Group Priority Projects } \\
\hline \hline 1 & Email/Directory Services & 6 & Configuration Control Board \\
\hline 2 & HelpDesk/APPLIX & 7 & Special Integration Project \\
\hline 3 & Commercial Off-the-Shelf (COTS) & 8 & NT Infrastructure \\
\hline 4 & Gartner Group & 9 & Desktop Guidelines \\
\hline 5 & Remote Access & 10 & Programmatic Procurement Systems \\
\cline { 2 - 5 } & & 11 & Enterprise Architecture Planning \\
\hline
\end{tabular}

\begin{tabular}{|c|l|r|l||}
\hline \multicolumn{3}{|c|}{ Information Technology Focal Areas } \\
\hline \hline 1 & $\begin{array}{l}\text { Functional Duplication and } \\
\text { Redundancy of Departmentwide } \\
\text { Information Systems }\end{array}$ & 10 & Age of Technology at Sites \\
\hline 2 & $\begin{array}{l}\text { Impact of Expanded E-mail use } \\
\text { Departmentwide }\end{array}$ & 11 & Throughput, Speed and Capabilities \\
\hline 3 & Internet Connectivity & 12 & Minimum Requirements for Desktop Platforms \\
\hline 4 & Unclassified Security & 13 & Consolidation of DOE Data Centers \\
\hline 5 & Standardization Strategies & 14 & Data Warehousing \\
\hline 6 & Departmental Procurement Opportunities & 15 & Corporate Systems Architectures * \\
\hline 7 & $\begin{array}{l}\text { Business relationships and Technical } \\
\text { Approaches }\end{array}$ & 16 & Workflow and Groupware * \\
\hline 8 & Benchmarks in Technology & 17 & Technology Assisted Learning * \\
\hline 9 & Migrations Toward Advances in Technology & & \multicolumn{2}{|l||}{} \\
\hline
\end{tabular}

3 Technical Focal Areas were presented in Information Architecture, Volume II, Baseline Analysis.

* Items 15, 16, and 17 were identified for Information Architecture, Volume IV, Vision. 


\section{Appendix E}

\section{Plan for DOE Headquarters \\ Corporate Systems Architecture}




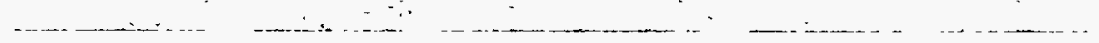




\section{Project Description}

The Enterprise Architecture Planning (EAP) process will be used to provide Department of Energy (DOE) Headquarters with a business based architecture for corporate systems. The architecture will be developed through facilitated group process. The process is repeatable and will mesh data, applications, and technology infrastructures into one cohesive migration plan and set of recommendations that take into account the dependencies between architectural elements. If followed, recommendations provide a high likelihood of success for implementing the plan.

\section{History}

This process was successfully used by the Office of Energy Research under the sponsorship of Dr. Martha Krebs (ER-1) and was executed by ER Core Process Experts and contractors from January through July 1997. On completion, Dr. Krebs characterized the ER architecture process, "This is a model for how to undertake corporate initiatives. There is a great deal more here than I expected." The result of the process was 41 specific, costed projects, extending over the next 5 years and designed to meet the business and technology needs of the organization.

\section{Assumptions and Constraints}

Requires executive-level sponsorship and support from outside the information technology (IT) community.

Requires committed part-time business experts from the DOE Headquarters (HQ) business community.

Requires representation from the DOE IT community to serve as a reference panel.

\section{Benefits and Outcomes}

Repeatable, business-based process is used for IT decisions.

Data, applications, and technology support the business model.

Benefits of an architected environment are measurable.

Funding identified to support IT projects is justifiable.

Migration plan allows orderly divestiture of older technologies.

A clear plan is developed for moving forward to meet business needs through a defined architectural process. 


\section{Schedule}

The schedule for executing the DOE Headquarters corporate systems architecture planning process is contained in the following Gantt chart.

Figure E-1, Headquarters Corporate Architecture Schedule

\begin{tabular}{|c|c|c|c|c|c|c|c|c|c|}
\hline \multirow[b]{2}{*}{ ID } & \multirow[b]{2}{*}{ Task Name } & \multicolumn{3}{|c|}{1998} & \multicolumn{5}{|c|}{1999} \\
\hline & & \begin{tabular}{|l|l|}
$A$ & $M$ \\
\end{tabular} & \begin{tabular}{|l|l|l|l|l|}
$\mathbf{J}$ & $\mathbf{J}$ & $\mathbf{A}$ & $\mathbf{S}$ \\
\end{tabular} & \begin{tabular}{l|l|l}
$O$ & $N$ & $D$
\end{tabular} & \begin{tabular}{|l|l|l|}
$J$ & $F$ \\
\end{tabular} & \begin{tabular}{l|l|l|}
$\mathbf{A}$ & $\mathbf{M}$
\end{tabular} & $\mathbf{J} \mid \mathbf{J}$ & $A \mid s$ & \begin{tabular}{l|l|l|l|l}
$\mathbf{S}$ & $\mathbf{O}$ & $\mathbf{N}$ & $\mathrm{D}$ & $\mathrm{J}$ \\
\end{tabular} \\
\hline 1 & Develop Project Plan & & 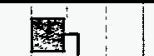 & & & i & & & $\therefore$ \\
\hline 2 & Form Team & & 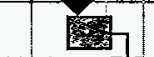 & & & & & & \\
\hline 3 & Just-In-Time Training & 4 & 庭 & & & & & & f \\
\hline 4 & Begin Team Sessions & & & $10 / 1$ & & $\vdots$ & & & \\
\hline 5 & Draft Principles, Vision and Scope & & & 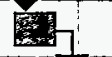 & & 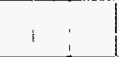 & & & i \\
\hline 6 & Develop Business Model & & : & P & 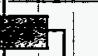 & . & & & 1 \\
\hline 7 & Develop Information Resources Catalog & & ; & 5 & 整 & & & & $!$ \\
\hline 8 & Develop Data Architecture & & & & 5 & in & & & \\
\hline 9 & Develop Applications Architecture & & & & & 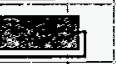 & & & 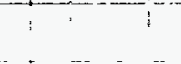 \\
\hline 10 & Develop Technology Architecture & & & & retse & 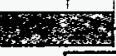 & & & \\
\hline 11 & Develop Migration Plan & & T & & 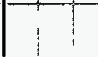 & & & & . \\
\hline
\end{tabular}




\section{Appendix F}

\section{Acronyms}


$\ldots-\ldots \ldots \therefore$

$\therefore \ldots+\ldots$ 
AES

AFIRM

ANSI

APPLIX

BMIS

CGG

CHRIS

CIAC

$\mathrm{ClO}$

cots

DB

DES

DIARB

DMS

DOCS

DOE

$E A$

EAP

ECIM

EDI

EIA

ER

ES\&H

FA

FIPS PUB
Advanced Encryption Standard

Association for Federal Information Resource Managers

American National Standards Institute

Helpdesk and Infrastructure Management

Business Management Information System

Corporate Guidance Group

Corporate Human Resource Information System

Computer Incident Advisory Capability

Chief Information Officer

Commercial-off-the-Shelf

Database

Data Encryption Standard

Departmental Information Architecture Review Board

Defense Messaging System

Document Online Coordination System

Department of Energy

Enterprise Architecture

Enterprise Architecture Planning

Executive Committee on Information Management

Electronic Document Interchange

Energy Information Administration

Office of Energy Research

Environmental Safety and Health

Technical Focal Area

Federal Information Processing Standard Publication 
FMIS

FOIA

FY

GA

GPRA

GSA

GUI

HCG

$H Q$

HR

IA

IBM

IDEF

IEC

IEEE

IM

IMPACT

IMSP

IRC

IRM

IRMPIT

IS

ISA

ISO

IT
Financial Management Information System

Freedom of Information Act

Fiscal Year

Gartner Advisory Services

Government Performance and Results Act of 1993

General Services Administration

Graphical User Interface

Headquarters Collaboration Group

Headquarters

Office of Human Resources and Administration

Information Architecture

International Business Machine

Integration Definition for Function Modeling

International Electrotechnical Commission

Institute of Electrical and Electronics Engineers

Information Management

Information Management Planning and Architecture Coordinating Team

Information Management Strategic Plan

Information Resources Catalog

Information Resources Management

Information Resources Management Process Improvement Team

Information Systems

Information Systems Architecture

International Standards Organization

Information Technology

Volume IV, Vision 
ITMRA

LAN

LANL

M\&O

NIST

NN

NT

OAP

OLE

OMB

PKI

ROI

SEAB

SIM

SIP

SQL

WAN

WWW
Information Technology Management Reform Act of 1996

Local Area Network

Los Alamos National Laboratory

Management and Operations

National Institute of Standards and Technology

Office of Nuclear and Non-Proliferation Support

New Technology (Windows ${ }^{\mathrm{TM}}$ )

Openness Advisory Panel

Object Linking and Embedding

Office of Management and Budget

Public Key Infrastructure

Return on Investment

Secretary of Energy's Advisory Board

Strategic Information Managemen

Special Integration Project

Structured Query Language

Wide Area Network

World Wide Web 


\section{Appendix G}

\section{References}


$+\ldots+1$ 


\section{Documents}

1. Cook, Melissa A., Building Enterprise Information Architectures. Prentice-Hall, 1996.

2. Covey, Stephen R., Principle-Centered Leadership. Simon and Schuster, 1990, 1991.

3. Emerging Technologies: Scholars assemble a comprehensive forecast of coming technologies. The Futurist, November-December 1997.

4. Magee, F., IT Architecture is a Process, Not a Document, Gartner Advisory Report, December 1997.

5. MATTER: Technology Evolution and Adoption: The Ten Year Outlook, Gartner Advisory Report, September 1997.

6. Raines, Franklin D., Funding Information Systems Investments, Policy. Memorandum for Heads of Executive Departments and Agencies, Executive Office of the President, Director's Office, Office of Management and Budget, October 25, 1996.

7. Spewak, Steven H., Enterprise Architecture Planning, Developing a Blueprint for Data, Applications and Technology. John Wiley and Sons, Inc., 1995.

8. U.S. Department of Energy, Information Architecture Volume I, The Foundations, March 1995, Assistant Secretary for Human Resources and Administration, Deputy Assistant Secretary for Information Management.

9. U.S. Department of Energy, Information Architecture Volume II, Baseline Analysis Summary, December 1996, U.S. Department of Energy, Assistant Secretary for Human Resources and Administration, Deputy Assistant Secretary for Information Management.

10. U.S. Department of Energy, Information Architecture Volume III, Guidance, March 1995, Assistant Secretary for Human Resources and Administration, Deputy Assistant Secretary for Information Management.

11. U.S. Department of Energy, Information Architecture, Profile of Adopted Standards, September 1997, Assistant Secretary for Human Resources and Administration, Deputy Assistant Secretary for Information Management.

12. U.S. Department of Energy Strategic Plan, September 1997, DOE PO-0053.

13. U.S. Department of Energy Information Management Strategic Plan, Partners for Progress in Corporate Management, September 1997, DOE/HR-0179. 
14. U.S. Department of Energy, Office of Energy Research, Strategic Information Planning Project Final Report, August 1997.

15. U.S. Department of Energy, Office of Energy Research, Strategic Information Planning Project Results and Recommendations, July 1997.

16. The Federal Chief Information Officer, Top Ten Challenge Survey, A Resource Paper Sponsored by the Association for Federal Information Resources Management (AFIRM), December 1997.

17. Zachman, John A., A Framework for Information Systems Architecture, IBM Systems Journal, September 1987. 


\section{Web Sites}

1. Best IT Practices in the Federal Government http://www.itpolicy.gsa.gov

2. Chief Information Officer (CIO) Council http://www.cio.fed.gov/

3. Department of Energy (DOE) http://www.doe.gov/

4. Departmentwide Software Management Program http://cio.doe.gov/smp

5. DOE Chief Information Officer http://cio.doe.gov/

6. DOE Corporate Human Resource System (CHRIS) http://wastenot.inel.gov/chris/chrishp.html

7. DOE Information Architecture http://www-it.hr.doe.gov/iat/iapro

8. DOE Information Management Council http://www-it.hr.doe.gov/imcouncil/

9. DOE Information Management Planning http://www-it.hr.doe.gov/implan/

10. DOE Information Technology Standards Program http://www-it.hr.doe.gov/standards/

11. DOEInfo http://doeinfo.doe.gov

12. DOE Solomon http://hst.dync.doe.gov/solomon/main.cfm

13. DOE Strategic Management System http://apollo.osti.gov/policy/sms/sms.html 
14. DOE Strategic Plan

http://www.doe.gov/policy/doeplan.html

15. DOE Year 2000

http://websparc.hr.doe.gov/year2000/index.html

16. Gartner Service

http://www.hr.doe.gov/gartner.htm

17. Office of Energy Research (ER) Strategic Information Planning http://www.er.doe.gov/production/er-60/

18. Performance Agreement between the Secretary of Energy and the U.S. President http://www.doe.gov/policy/library/sagree97.html 